\title{
Sustaining the employability of the low skilled worker
}

Citation for published version (APA):

Sanders, J. (2016). Sustaining the employability of the low skilled worker: development, mobility and work redesign. [Doctoral Thesis, Maastricht University]. ROA. https://doi.org/10.26481/dis.20160708js

Document status and date:

Published: 01/01/2016

DOI:

10.26481/dis.20160708js

Document Version:

Publisher's PDF, also known as Version of record

\section{Please check the document version of this publication:}

- A submitted manuscript is the version of the article upon submission and before peer-review. There can be important differences between the submitted version and the official published version of record.

People interested in the research are advised to contact the author for the final version of the publication, or visit the DOI to the publisher's website.

- The final author version and the galley proof are versions of the publication after peer review.

- The final published version features the final layout of the paper including the volume, issue and page numbers.

Link to publication

\footnotetext{
General rights rights.

- You may freely distribute the URL identifying the publication in the public portal. please follow below link for the End User Agreement:

www.umlib.nl/taverne-license

Take down policy

If you believe that this document breaches copyright please contact us at:

repository@maastrichtuniversity.nl

providing details and we will investigate your claim.
}

Copyright and moral rights for the publications made accessible in the public portal are retained by the authors and/or other copyright owners and it is a condition of accessing publications that users recognise and abide by the legal requirements associated with these

- Users may download and print one copy of any publication from the public portal for the purpose of private study or research.

- You may not further distribute the material or use it for any profit-making activity or commercial gain

If the publication is distributed under the terms of Article $25 \mathrm{fa}$ of the Dutch Copyright Act, indicated by the "Taverne" license above, 
Sustaining the employability of the low skilled worker: Development, mobility and work redesign 
(C) Jos Maarten Arnold Frank Sanders, Maastricht 2016

All rights reserved. No part of this publication may be reproduced, stored in a retrieval system, or transmitted in any form, or by any means, electronic, mechanical, photocopying, recording, or otherwise, without the prior permission in writing, from the author.

Published by ROA

Postbus 616

6200 MD Maastricht

ISBN: 978-90-5321-546-3

Printed in the Netherlands by Canon 


\title{
SUSTAINING THE EMPLOYABILITY OF THE LOW SKILLED WORKER: DEVELOPMENT, MOBILITY AND WORK REDESIGN
}

\author{
DISSERTATION
}

to obtain the degree of Doctor at Maastricht University, on the authority of the Rector Magnificus, Prof. dr. L. L. G. Soete

in accordance with the decision of the Board of Deans, to be defended in public on Friday 8 July 2016, at 10.00 hours

by

Jos Maarten Arnold Frank Sanders 


\section{Supervisors:}

Prof. dr. A. de Grip

Prof. dr. R.W.B. Blonk, Universiteit Utrecht

\section{Assessment Committee:}

Prof. dr. W.H. Gijselaers (chairman)

Prof. dr. B.I.J.M. van der Heijden, Radboud Universiteit

Prof. dr. R.F. Poell, Tilburg University

Prof. dr. R.K.W. van der Velden 


\section{Sustaining the}

Employability of the Low Skilled Worker:

Development, Mobility and Work Redesign 


\section{Contents}

Dankwoord 1

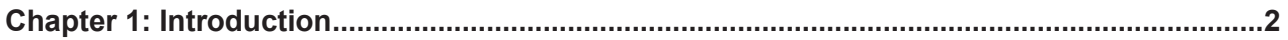

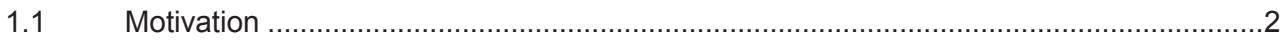

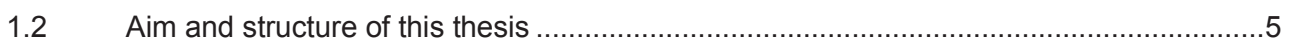

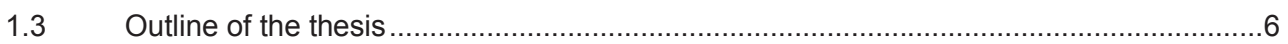

Chapter 2: Sustainable Employability: a dynamic perspective ............................................11

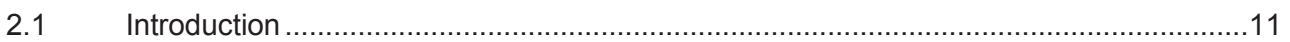

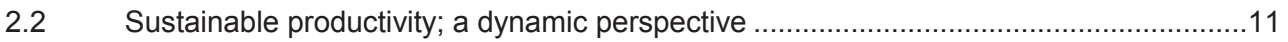

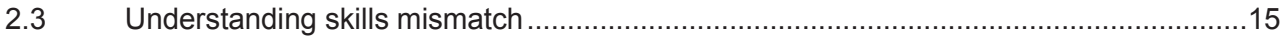

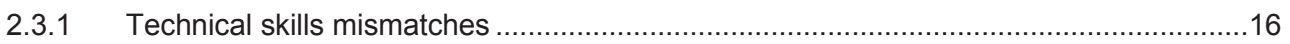

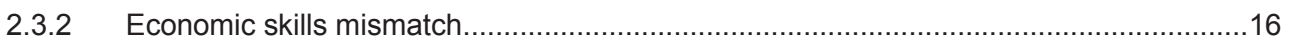

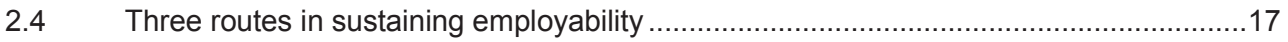

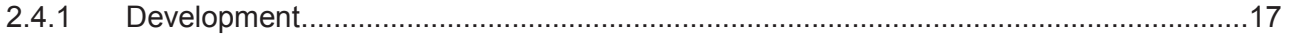

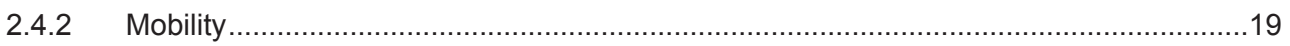

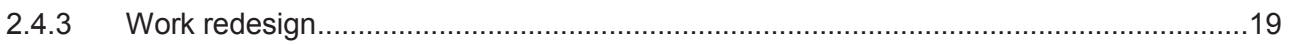

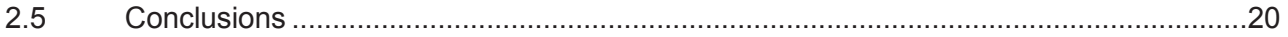

Chapter 3: Explaining less educated employees' training intentions.................................23

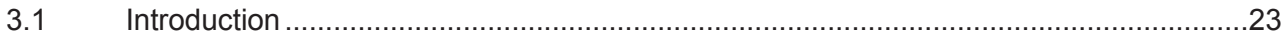

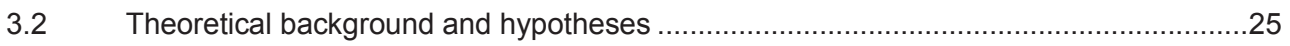

3.2.1 Theories of planned behaviour and social cognitive theory .......................................25

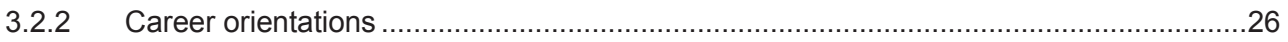

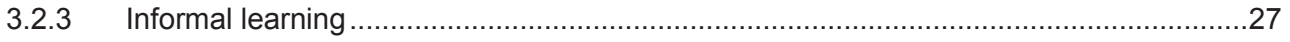

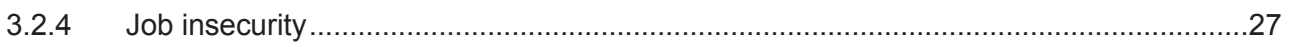

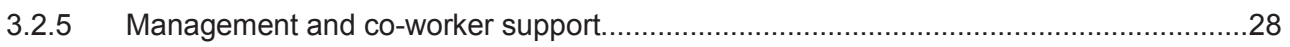

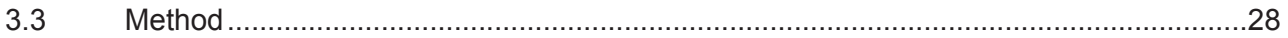

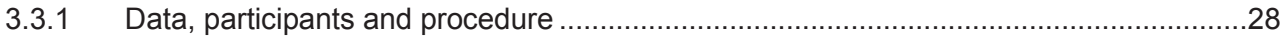

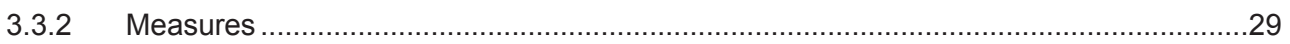

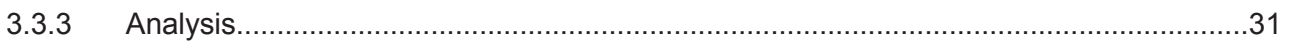

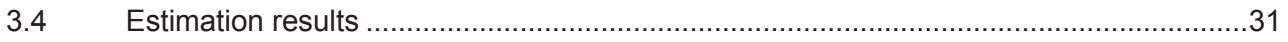

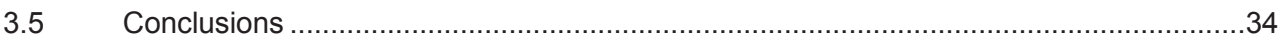


Chapter 4: Are positive learning experiences levers for lifelong learning among less

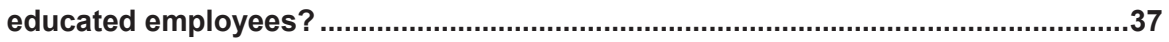

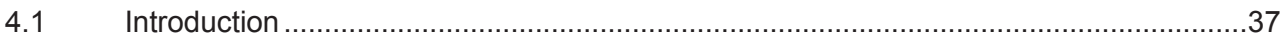

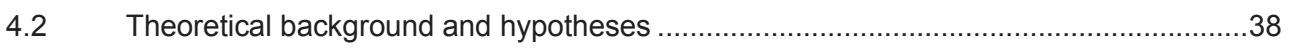

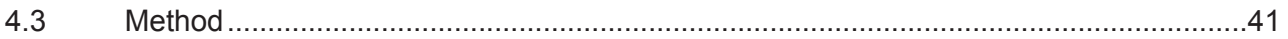

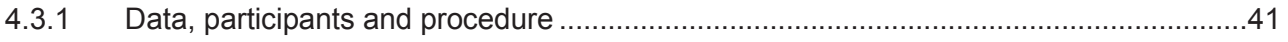

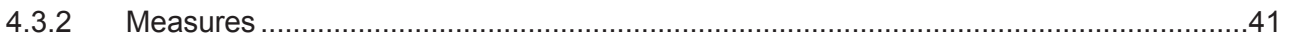

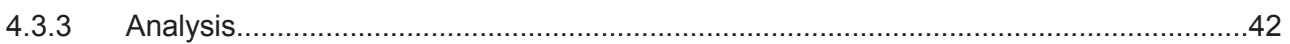

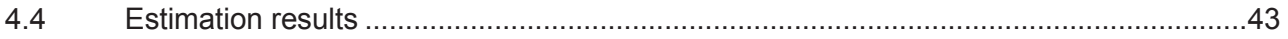

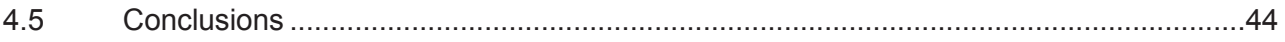

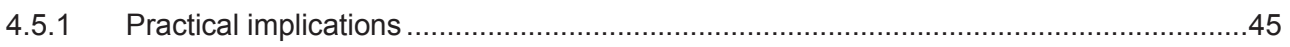

4.5.2 Limitations and directions for future research .........................................................46

Chapter 5: Job-to-job mobility among less educated older employees ..............................48

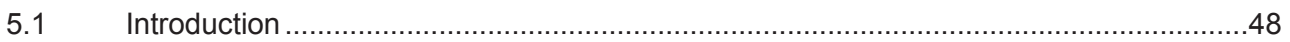

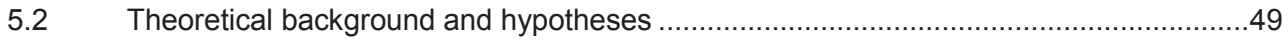

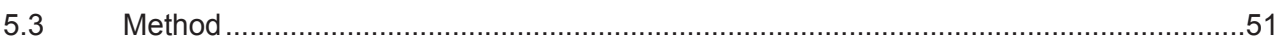

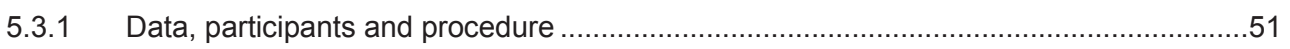

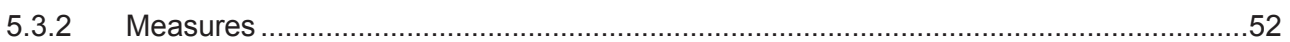

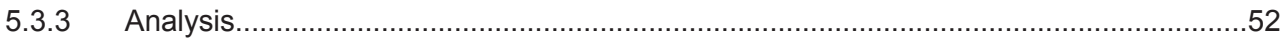

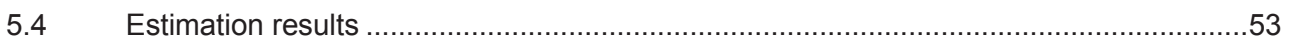

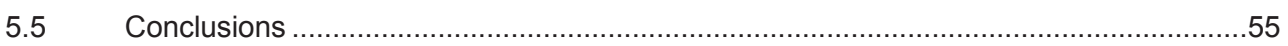

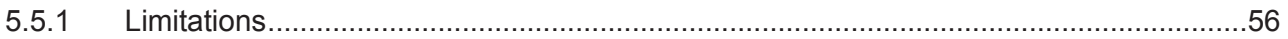

Chapter 6: Sustaining less educated older employees' employability: exploring

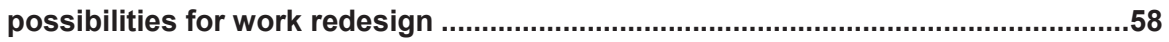

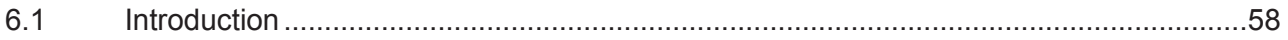

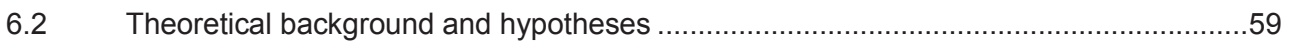

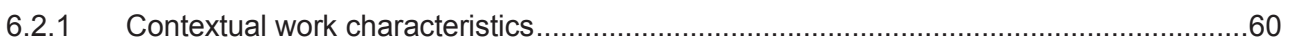

6.2.2 Cognitive-informational and task-motivational work characteristics .............................60

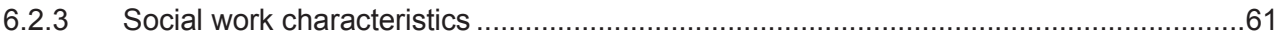

6.2.4 Work characteristics, work ability and work motivation ..........................................61

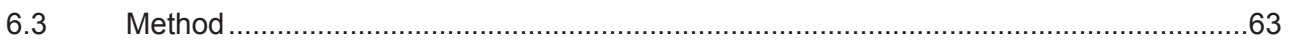

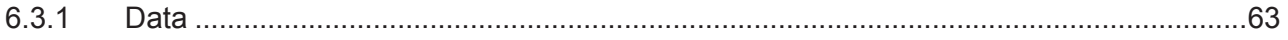

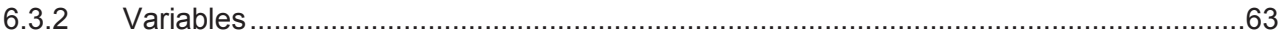

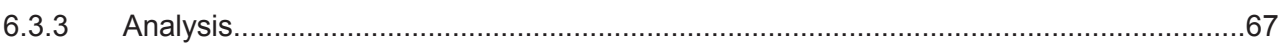


6.4 Estimation results

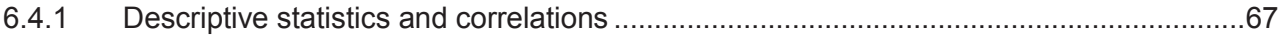

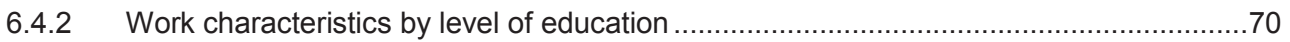

6.4.3 Work characteristics, work ability and work motivation ...................................................71

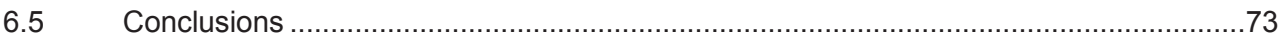

6.5.1 Work characteristics and relationships with work ability and work motivation (research questions 1 and 2) ...............................................................................

6.5.2 Work redesign possibilities (research question 3 ) …..................................................75

Chapter 7: Impact of developmental, mobility and work redesign activities on skills

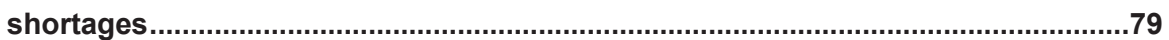

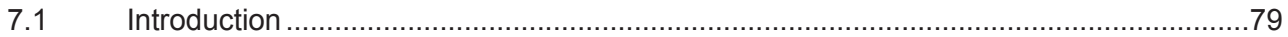

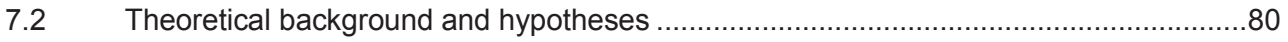

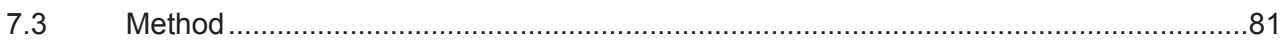

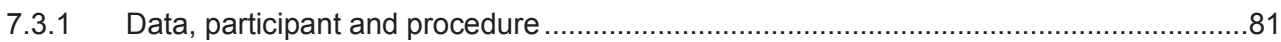

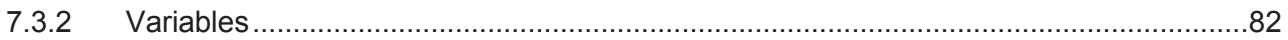

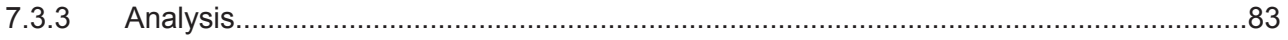

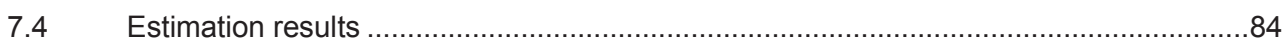

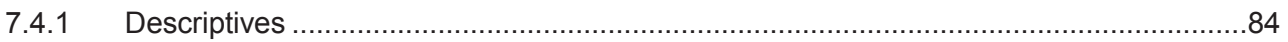

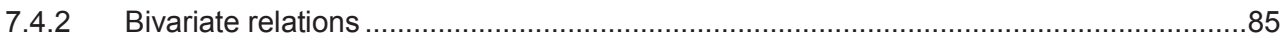

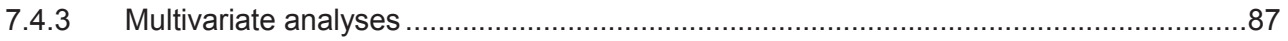

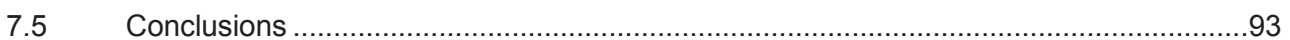

7.5.1 Limitations and directions for further research ...........................................................

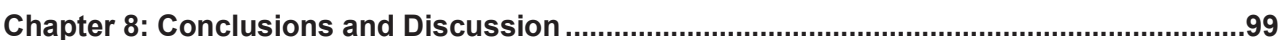

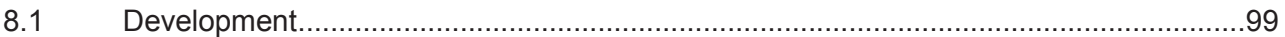

8.1.1 Pre-training self-efficacy and the role of positive learning experience .........................99

8.1.2 Recovering from perceived skills shortages; development activities...........................100

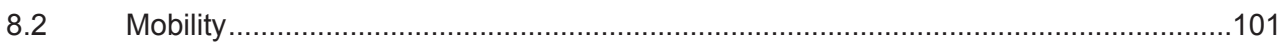

8.2.1 Recovering from perceived skills shortage; mobility activities ....................................101

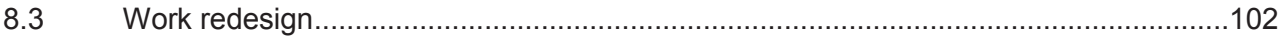

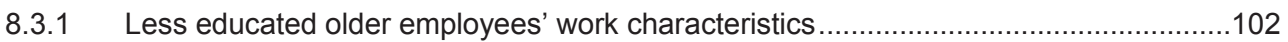

8.3.2 Relationships between work characteristics, work ability and work motivation .............102

8.3.3 Recovering from perceived skills shortages; work redesign .......................................103

8.4 Recovering from skills shortage in unstable organisations: a challenge ......................104 


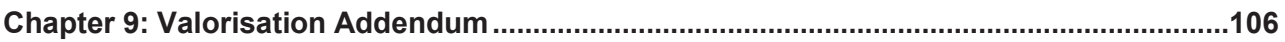

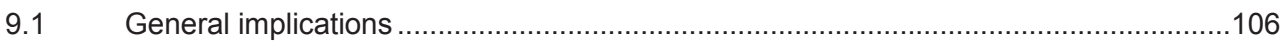

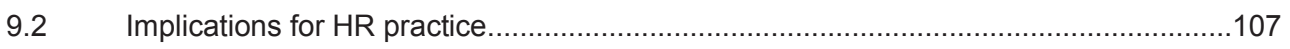

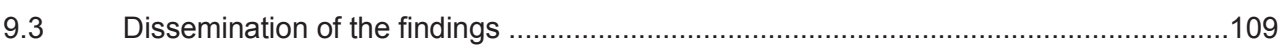

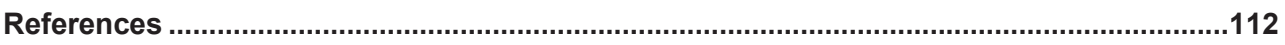

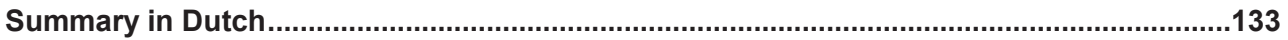

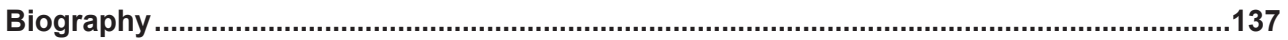




\section{Dankwoord}

"Alia iacta est"....

Zo begon ik het dankwoord van mijn afstudeerscriptie over Employability in het Bankwezen in 1998. Een beetje interessant doen met een stukje Latijn. Hoe jammer dat juist het toevoegen van die drie woorden betekende dat ik mijn afstudeerscriptie destijds ben gestart met een uiterst pijnlijke spelfout. In het eerste woord! Een schande....en een frustratie.

Om die schande uit te wissen en mezelf te verlossen van die frustratie, ben ik met dit proefschrift begonnen en daarom begin ik dit proefschrift met het rechtzetten van de misser van toen.

"Alea iacta est!" Dat moest het zijn!

Nu dat is rechtgezet, wil ik iedereen bedanken die me geholpen heeft deze 'teerling' te werpen.

In het bijzonder gaat mijn dank uit naar mijn promotoren. Andries en Roland. Te beginnen met Andries. Welk een voorrecht is het om al zo lang en zo prettig en constructief met jou te kunnen werken. Vanaf de start van mijn onderzoeksstage bij ROA in 1997 tot aan dit proefschrift in 2016 was jij mijn gids in het land van de wetenschap. Afspraak is afspraak, een woord een woord. Vertrouwen, focus, rust, kritisch, constructief en altijd tijd. Altijd! Hoe doe je dat? Hoe het ook zij. Zonder jou was dit proefschrift er niet geweest. Mijn dank is groot en ik hoop op deze manier nog vele jaren samen te kunnen werken aan de ontwikkeling van mooie en nuttige kennis over leren en ontwikkelen in de dynamische arbeidscontext van de 21 ste eeuw.

En Roland. Al sinds het begin van mijn werkzaamheden bij TNO in 2004 richten wij ons op die onderkant. Het is een groot voorrecht om aan jouw zijde te mogen strijden tegen de ineffectiviteit van Neerlands re-integratiebeleid. Wat een energie en doorzettingsvermogen! Ik ken niemand die met zoveel plezier en enthousiasme tegen de wind in zeilt als jij. Met de ogen wijd open. Vrij, open, kritisch, constructief en nooit tijd. Nooit! Hoe doe je dat? Hoe het ook zij. Zonder jouw inspiratie, inzet en vertrouwen was dit proefschrift er niet gekomen en mét jouw inspiratie, inzet en vertrouwen zeilen we nu samen door om duurzame inzetbaarheid verder te borgen in alle lagen en, wat mij betreft, re-integratiebeleid dan maar meteen volledig overbodig te maken...

Naast mijn promotoren wil ik mijn (oud-)collega's bij TNO ongelofelijk hard bedanken. Eerst de (Ex) TNO All-Stars van 2.13 en omstreken: Luc, Laura, Ellen, Kyra en Oleg. Weg bij TNO en ik mis jullie nog dagelijks. Een speciaal woord van dank aan Ellen, die me, samen met Jo Thijssen en Peter Leisink in 2011 op het (on)zalige idee bracht dit proefschrift (of was het toch een ander proefschrift?) te schrijven en die me altijd bij de les hield. 
Aan Luc, die gelukkig mijn paranimf wilde zijn en die mij de afgelopen jaren onder het genot van bier, pizza of slechte koffie, voortdurend van mijn stuk wist te brengen. Mijn eigen ontwikkelroute. Heel fijn. En aan Laura, voor de lach en de traan, voor feestjes met Mojito mannen, voor kleur- en kledingadvies en voor alles wat bijzondere mensen bijzonder maakt. Berenschot vaart er wel bij.

Ik wil ook al die andere (oud) TOPPERS bij TNO bedanken die maken dat ik $90 \%$ van de tijd oprecht lol heb in mijn werk (de rest is administratie). Ik ga mensen vergeten. Sorry alvast. Ik noem Francel, Jenny, Henny, Anneke, Sarike, Steven, Klaas, Friso, Astrid en alle Paulen, Peters en Wouters. Ik noem ook de Robben en Pim en Dagmar en ik noem Shirley, Edwin, Jan, Saskia, Aukje, Joost, Cees, Bruno, Suzanne en ik noem alle Femkes. En ik noem zeker ook Karolus, Seth, Goedele, Ernest en Swenneke. Hoezo ander team? En ik noem Dick en Debby, Fietje, Irene, Paulien, Brigitte, Tinka, Ton, Rien, Jan Fekke, John, Patrick en Eddie en zo kan ik nog wel even doorgaan. TNO is een inspirerende omgeving met dito mensen die stuk voor stuk slimmer zijn dan ik. Intimiderend. Grote dank aan allen!

Maar voordat je gaat werken ben je thuis. Ik wel ten minste. En ik heb een heel tof 'thuis'. En dat 'thuis' wil ik hier ook heel hard bedanken. Te beginnen met die twee druktemakers. Flip en Cato bedankt! Fijn dat ik niet 's nachts wakker heb hoeven liggen van dit proefschrift (maar hele nachten kon rondlopen met één van jullie op de arm) en dat ik de uren tussen die nachtwandelingen door kon slapen als een blok (uitgeput). Ik ben echt heel blij dat dit proefschrift nu klaar is en dat ik nu ELKE vrije dag kan gaan besteden aan SPELEN, aan pretparken, kermissen, dierentuinen, zwembaden en springkussens. Geen Koningsdag meer voor de samenvatting en geen Hemelvaartsdag voor referenties. Alles is nu voor jullie! En alles is ook voor Vanes. Mijn absolute rustpunt in deze wereld vol druktemakers. Met jou is het leven sowieso een feest. Kom maar door met de rest.

Mijn thuis is ook mijn ouders en schoonouders. Pa en Ma, Joop en Vivienne. Dank voor jullie niet aflatende belangstelling ("is dat proefschrift nou nog niet af?"), voor jullie bereidheid om me zo nu en dan van die druktemakers te verlossen, ook al kostte jullie dat heel wat uurtjes nachtrust. En dank dat jullie er altijd zijn om me te helpen aan een stukje ontspanning, fijne gesprekken en spontane feestjes met of zonder aanleiding. Dank! En nu met z'n allen naar de golfbaan voor die single handicap!

En mijn thuis is ook Mark, Saar, Luka en Milo, Maike, Arjan, Evelyn, Floor en Femke en Erik, Lien en Luuk. Het is bij jullie altijd thuiskomen. Of het nou Utrecht, Atlanta of Deurne is. Een warm bad, waar ik graag in lig. Ook jullie wil ik oprecht bedanken voor jullie support. Een familie om héél trots en héél zuinig op te zijn en een familie om veel meer tijd mee door te brengen. 
En dan zijn er nog een paar andere mensen die ik wil bedanken. Mensen die ook heel belangrijk voor me zijn. Allard. Vriend, getuige en nu dus ook mijn paranimf. Dank voor alle kilometers die wij samen maken. Op de fiets, in de auto en aan tafel bij goede (of niet zo goede) glazen 'regionale producten'. Dank voor je drive, je focus, je tijd en je goede voorbeeld, en dank voor je plezier en spelvreugde. Er komt nu hopelijk ook meer tijd om te SPELEN. Ik kijk er erg naar uit om dat samen te doen! En met Allard dank ik ook ál mijn vrienden en vriendinnen die de afgelopen jaren voor passende afleiding hebben gezorgd. Door met me te gaan fietsen of golfen, hockeyen of skiën, squashen of tennissen, eten of borrelen, kolonisten, pub-quizjes of iets veel ingewikkelders en wat dan ook... Gaan we met z'n allen mee door!

Een woord van dank ook nog aan Bob, Charlot, Yvonne, Frank, Johan, Janneke, Aarjen, Olga, Wynand, Marc, Dirk, Ted en al die andere mensen die mij met hun onderzoeksopdrachten de gelegenheid hebben geboden mijn prachtige werk te kunnen doen.

En ten slotte ben ik veel dank verschuldigd aan Marc Damen en Karen van Dam met wie ik met veel plezier heb samengewerkt aan het vierde hoofdstuk van dit proefschrift.

Het is af.... we kunnen door...

Jos Sanders, Amsterdam, 2016 


\section{Introduction}




\section{Chapter 1: Introduction}

\subsection{Motivation}

Sustainable employability has recently become a topical issue in HR literature. Two major developments are responsible for this increased attention. The first is contextual change causing rapid shifts in the demand for labour and skills (Caroli \& Van Reenen, 2001; Bresnahan, Brynjolfsson, \& Hitt, 2002; Brynjolfsson \& McAfee, 2014). These shifts have grave consequences for the employability of individual employees. They even cause skills to become obsolete (De Grip \& Van Loo, 2001; Sanders \& Kraan, 2013). Scholars like Kaufman (1989), Van Loo, De Steur and De Grip (2001), Allen and Van der Velden (2002), and more recently for the Netherlands, Sanders and Kraan (2013), show that organizational change is positively related to perceived skills mismatch. Allen and Van der Velden (2002) show that the speed with which changes take place accelerates this process and Alders (2005) adds that especially sudden changes or 'shocks' speed up shifts in the demand for skills.

Contemporary contextual changes are often (computer) technology driven. Neuman and Weiss (1995), Allen and Van der Velden (2002), Gould, Moav and Weinberg (2002) and Brynjolfsson and McAfee (2014) have pointed to technological change as being an important cause for shifts in skills demands. Examples are the widespread use of computers, robots, the internet, email, online services and social media. For instance, from the 1980 s onwards computers have gradually taken over more and more routine-tasks, such as archiving and accounting (see also: Soete \& Ter Weel, 2005), making the specific skill to archive, administer or account by hand of less value to the labour market. Many employees have benefited from these technological and organizational changes (Acemoglu \& Autor, 2011). For instance, thanks to computer technology, employees can focus on new, innovative and more productive tasks (Autor, Levy, \& Murnane, 2003; Borghans, Ter Weel \& Weinberg, 2014). Others, however, may find themselves in a more vulnerable position on the labour market. Generally speaking, vulnerable groups are those who on the one hand possess the skills that have become of less value to the labour market due to technological and organizational change and who on the other hand lack the skills that have become more valuable because of these same changes. Allen and Van der Velden (2002), Sanders (2005), Soete and Ter Weel (2005) and Akcomak, Borghans and Ter Weel (2011) point to less educated employees as being a vulnerable group. Less educated employees are most likely to be replaced by new (computer) technologies and they have been shown to have greater trouble keeping up with technological and organizational changes. Bresnahan, Brynjolfsson and Hitt (1999), Brynjolfsson and McAfee (2014) have already suggested that intermediately and 
even higher educated employees are also becoming more vulnerable since, with computers becoming more powerful by the day, some of their tasks can also be taken over by computers. Goos, Manning and Salomons (2014) show that it are especially those stuck in the middle wage jobs who are most affected. However, these employees will start competing for the available low wage jobs and crowd out the less educated from this job domain. As a consequence, the vulnerable employability of less educated or uneducated employees will become ever more vulnerable as a result of contextual changes and shifting skills demands.

The second major development that makes sustainable employment a topical issue, is the ageing of the (working) population which causes shifts in the supply of labour and skills. In most developed countries, populations are ageing (United Nations, 2013) which is reflected in the rapid ageing of the working population in most developed countries (OECD, 2014). This confronts most Western economies with serious threats related to the affordability of pension and social security systems. Extending people's working lives is generally considered a viable option to reduce these threats. However, if individuals have to extend their working lives, labour market and HR policies need to facilitate both individuals and companies to sustain older workers' employability. This particularly holds for less educated workers whose employability is most vulnerable due to technological and organizational change.

In this thesis, I analyse three potential routes in sustaining the employability of less educated workers: development, mobility and work redesign. I focus on the less educated, since literature shows that less educated (older) employees are a high-risk group with regard to their sustainable employability. Less education and training, worse general health (habits) and taxing working conditions (Kraan, Van Zwieten, Sanders \& Wevers, 2014) make it relatively difficult for less educated older employees to extend their working lives. Adding to this, less educated employees face several other disadvantages hindering their sustainable employability. These disadvantages refer to the domains of (1) development, (2) mobility and (3) work redesign.

1. Less educated employees participate less often in training than intermediately and higher educated employees. This training gap has been widening in recent years (Borghans, Fouarge, De Grip \& Van Thor, 2014). Moreover, less educated employees find possibilities for development relatively unimportant (Kraan et al., 2014), and according to Illeris (2006) and Fouarge, Schils and De Grip (2013) they are significantly less motivated to participate in formal training courses. Training and learning are, however, widely considered key ways to remain employable (De Grip, van Loo \& Sanders, 2004; Van der Heijden, Boon, van der Klink, \& Meijs, 2009a) and employability has been shown to help employees remain capable of building up new expertise (Van der Heijden, De Lange, Demerouti, \& van der Heijde, 
2009b) and decrease skills obsolescence (Kaufman, 1989). So why do less educated employees participate less in training? Fouarge et al. (2013) show that the reasons for less educated employees to not invest in further training are the same reasons they had for hardly investing in their initial education. These are a lack of openness to experience, an external locus of control, a higher level of exam anxiety due to prior failures (see also Tharenou, 2001), a lack of orientation on the future and a preference for leisure instead of work (see also Borghans, Duckworth, Heckman \& Ter Weel (2008). As less educated employees are less inclined to accumulate skills by education and training as their careers progress, their employability gradually becomes more fragile.

2. Less educated employees lack sufficient experience in job-to-job mobility as they are generally less mobile across jobs (Gesthuizen \& Dagevos, 2005; Zwinkels, Ooms, \& Sanders, 2009). When mobile, less educated employees are mobile on the 'internal' labour market and not on the external labour market (Sanders \& De Grip, 2004). Moreover, when less educated employees are mobile, this is often involuntary, for example due to reorganizations or conflicts (Hooftman, van der Klauw, Klein Hesselink, Terwoert, Kraan, Jongen, Kraan \& Wevers, 2012). Salverda (2011) shows that in the Netherlands less educated employees' upward internal career paths are generally limited and better job alternatives in the external labour market are scarce, and hard to reach. As mentioned, less educated employees run a high risk that their work will be automatized or offshored. This not only threatens them with job loss but also limits their possibilities to find a new job (De Beer, 2006; Steemers, 2010). The relative lack of job-to-job mobility among less educated employees implies that their job tenures are often longer. Therefore they face a 'job lock' more frequently (Gesthuizen \& Scheepers, 2010). Getting stuck in a job would not be an issue if that job remains and if an employee is able to use and build skills for that job and remains motivated to do so. For less educated employees, however, these conditions are hardly ever met. Many jobs are highly susceptible to changes due to technological and organizational change or offshoring, leaving many low skilled workers at risk of becoming unemployed (see also Salvanes, 2004; Görg, 2011; Brynjolfsson \& McAfee, 2014) and their skills becoming obsolete (Kaufman, 1989).

3. Borghans et al. (2014) have recently shown that less educated employees have gradually come to spend less time performing tasks from which they learn. This suggests that less educated employees get stuck in 'routine jobs'. This has shown to be highly demotivating when employees get older and increasingly start preferring tasks that offer them opportunities to utilize their skills (Warr, 2008; Kooij, 2010). Adding to this, Ybema, Geuskens and Oude Hengel (2009) found that the flexibility in structuring one's daily working 
hours (workday design; Elsbach \& Hargadaon, 2006) has an important positive effect on older employees' capabilities to work until the age of 65. Apart from job-to-job mobility, redesigning the job so that it keeps matching one's skills and motivation could also be an important strategy for optimizing skills use and workers' sustainable employability. Recent studies into the effects of job crafting interventions (Wrzesniewski \& Dutton, 2009; Dorenbosch, Gründemann \& Sanders, 2011a; van Vuuren and Dorenbosch, 2011 and Tims, 2013) and multi-jobbing (Bell, Hart \& Wright, 1997; Wu, Baimbridge, \& Zhu, 2009; Panos, Pouliakas, \& Zangelidis, 2009; Dorenbosch \& Sanders, 2010; Huiskamp, Sanders \& van den Bossche, 2011 and Dorenbosch, Sanders \& Beudeker, 2015) show promising results, albeit mainly for higher educated workers. So far, less educated employees appear to lack the resources (e.g. autonomy, decision latitude) or capabilities to redesign their own job (see also Kraan et al., 2014), causing their employability to become more vulnerable. This raises the question whether changes in work characteristics through (re)design could contribute to less educated older employees' sustainable employability.

This thesis aims to contribute to the literature on sustaining less educated employees' employability by answering five questions. Table 1.1 shows these five questions.

Table 1.1 Research questions of the following chapters

1. How can we conceptualize sustainable employability?

2. How can less educated employees be stimulated to take the development route towards sustainable employability?

3. How can less educated older employees be stimulated to take the mobility route towards sustainable employability?

4. How can less educated older employees be stimulated to take the 'work redesign' route towards sustainable employability?

5. Which routes are effective for less educated older employees?

This thesis is structured as follows: Chapter 2 provides a dynamic framework for studying sustainable employability. Chapters 3 and 4 examine less educated employees' training intentions and the role of positive learning experiences in stimulating less educated employees to participate in training. Chapter 5 examines the role of self-efficacy in stimulating less educated older employees job-to-job mobility. Chapter 6 examines less educated older employees' possibilities for work redesign which could contribute to sustainable employability. 
Chapter 7 examines the effects of taking part in activities on the development, mobility and work redesign routes on the chance that less educated older employees recover from a perceived skills shortage. Figure 1.1. summarizes the topics and the structure of this thesis.

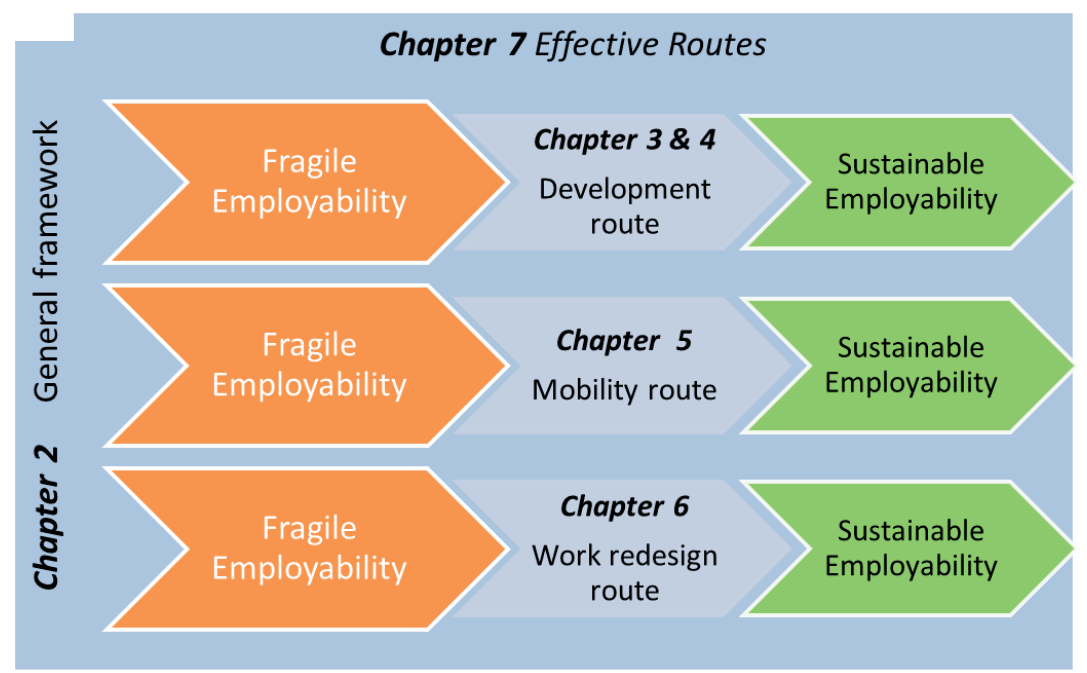

Figure 1.1 Topics and structure of the issues

\section{$1.3 \quad$ Outline of the thesis}

\section{Chapter 2: The Fragility of Employability: a dynamic perspective}

In Chapter 2, I define sustainable employability as the dynamic process of maintaining the match between what an employee is able and willing to do (skills, abilities and motivation) and what work demands and provides (skills, abilities and motivators). I show that individual employability is more or less constantly fragile as a consequence of recurring skills and motivation mismatches. A skills mismatch implies a mismatch between the skills and abilities required for a job and those an employee possesses. Skills mismatch may involve skills shortage or knowledge deficits, which occurs when employees do not or do no longer have the skills required for their current job. The perception of skills shortage and the routes to prevent or resolve it are the focus of this thesis. Next, I argue that sustaining employability involves targeted strategies for continuously (self) matching of a worker's skills to the skills demanded in the job in order to prevent a skills shortage. For this (re)matching process I identify three 'routes': development, mobility and work redesign. The development route refers to adapting one's skills to the skills the job requires (or will require in future) through formal or informal learning. The mobility route refers to reallocating a worker within or outside the organization with the aim to better match a worker's skills set to the skill demands in his or her job. The work redesign route refers to optimizing the use of a worker's 
skills set through redesigning tasks and work processes in the job. In Chapter 2, I argue that development, mobility and work redesign are potential routes to improve the skills match between worker and work, and therefore to sustain workers' employability.

\section{Chapter 3: Explaining less educated employees' training intentions}

In Chapter 3, data from the three waves of the longitudinal Study on Life Long Learning and Employment are used to examine how less educated employees can be stimulated to participate in training. Building on Ajzen and Fishbein's Theories of Planned Behavior (TPB) and Reasoned Action (TRA) (Fishbein \& Ajzen, 1975; Ajzen, 1985; 1991) and Bandura's Social Cognitive Theory (Bandura, 1982), findings are that differences in training participation are largely explained by differences in training intentions and that these training intentions can be stimulated by improving less educated employees' general attitude towards training ('Training is a good thing') and their pre-training self-efficacy ('I can successfully take part in training').

\section{Chapter 4: Are positive learning levers for lifelong learning among less educated employees?}

Building on results of Chapter 3, Chapter 4 examines one way of improving less educated employees' pre-training self-efficacy: gaining positive learning experiences. Chapter 4 first shows that training participation as such does not affect less educated employees' learning self-efficacy. However, if this training participation is considered a positive learning experience, it does have a positive effect on less educated employees' learning self-efficacy. Although the sample of employees with actual training experience is small and does not allow to draw conclusions for all less educated employees, results in Chapter 4 are in line with Bandura's Social Cognitive Theory (Bandura, 1982) and earlier empirical findings by for instance Illeris (2006). Based on these findings, I suggest that both management and co-worker support should primarily aim at increasing the quality of less educated employees' learning experiences as this makes learning a positive experience which triggers lifelong learning.

\section{Chapter 5: Job-to-job mobility among less educated older employees}

Following Ajzen and Fishbein's TRA and TPB and Bandura's SCT (1977), Chapter 5 analyses whether strengthening less educated employees' confidence in their own abilities (self-efficacy) to seek and find a new employer is a pretext for voluntary external mobility. Here I specifically focus on older less educated employees (age 45-64). Chapter 5 shows that confidence in one's own abilities indeed has a positive correlation with both the intention to change employers and actual job-to-job mobility. It also shows that less-educated older employees are less confident and have weaker intentions to change jobs than higher educated older employees. The relationship between confidence and intentions, however, does not vary between lower and higher educated 
employees. These findings imply that strengthening the confidence of less educated over-45s in a successful job-to-job transition can lead to more voluntary external mobility.

Chapter 6: Sustaining the employability of less educated older employees: directions for work design

Chapter 6 examines directions for work redesign that could lead to the creation of more sustainable jobs for less educated older employees, building on the classic Job Characteristics Model developed in Hackman and Lawler (1971) and Hackman and Oldham (1980) and the expansions of this model suggested by Karasek (1979), Humphrey et al. (2007) and Grant and Parker (2009).

Chapter 6 shows that less educated older employees score higher on contextual work characteristics such as dangerous work, physical strain and repetitive work. It also shows that contextual work characteristics are negatively related to work ability and job satisfaction. These findings suggest that redesigning contextual work characteristics seems promising. Cognitive informational work characteristics, such as job complexity, time pressure or task demands, are not related to work ability or work motivation. Redesigning these characteristics therefore seems less promising. For task motivational work characteristics only redesigning efforts aimed at increasing task variety seem promising. Finally, on social work characteristics, such as social support from colleagues or supervisors, emotional work and contact with customers, Chapter 6 shows that less educated older employees may benefit from redesigning efforts aimed at increasing support as well as through decreasing the emotional workload. Generally, findings suggest that work redesign is a promising strategy for sustaining less educated older employees' employability when social and contextual work characteristics are the object of redesign.

Chapter 7: Sustaining the employability of less educated older employees: development, mobility or word redesign?

Finally, Chapter 7 examines the effects of specific skill development, mobility and work redesign activities on the chance that less educated older employees recover from a perceived skills shortage. For skill development the effects of participating in three activities are analysed: substantial training (more than 5 days), short training (1-5 days) and instructions or training on the job. Chapter 7 shows that less educated older employees who take part in substantial training are more likely to recover from a perceived skills shortage. However, whether or not they receive instructions or training on the job or participate in shorter training does not make a difference. With respect to mobility, the effects of changing jobs, getting promoted and getting demoted are analysed. With respect to work redesign, the effects of getting fewer tasks, getting more tasks and getting different tasks are analysed. Findings show that neither the mobility activities, nor the 
work redesign activities, are effective. None of these activities increase the chance of recovering from a perceived skills shortage, implying that they do not contribute to a better skills match. Getting demoted or getting fewer tasks even decreases the chance of recovering from a perceived skills shortage, instead of increasing it. Finally, Chapter 7 shows that older employees who are employed in stable organizations are more likely to recover from a perceived skills shortage than older employees in less stable organizations. 


\section{Sustainable Employability}




\section{Chapter 2: Sustainable Employability: a dynamic perspective $^{1}$}

\section{$2.1 \quad$ Introduction}

The issue of Sustainable employability has been moving up the public and political agenda for several years. Demographic trends in the working population and increasing contextual and technological changes play a dominant role in this increased attention for sustainable employability in all developed countries. In the Netherlands, various measures have been taken to extend people's working lives and thus keep the social security system affordable. Examples of these measures are closing off early retirement routes, the gradual increase of the AOW age from 65 up to 67 , the introduction of bonuses and assurances for employers who hire or retain (older) employees, mobility bonuses for employees, the co-funding of sector plans and the action plan "55+works". These policies are expected to sustain employees' employability. These measures also stress the growing responsibilities of employers and employees themselves to help supply the labour that will be in demand on tomorrow's labour market. This urges them to play a proactive role in the dynamic process of matching skills and motivation to work itself as well as to the changing context of that work. This is what 'sustainable employability' is: a continuous process of matching between what an employee is willing (needs) and able (abilities) to do and what work demands (demand) and provides (values). In this chapter, we provide a framework on the fragility of employability and introduce three potentially effective routes in sustaining employability: development, mobility and work redesign.

\subsection{Sustainable productivity; a dynamic perspective}

Employability is about the likelihood of retaining meaningful and challenging work: a job in which a person can remain healthy and productive until one's retirement age and maybe beyond. Policies that focus on skills mismatch prevention make frequent reference to the concept of employability. Forrier and Sels (2003) define employability as 'the likelihood of a job on the internal or external labour market'.

1 This chapter is based on: Sanders, J., Dorenbosch, L., \& Blonk, R. (2015). The fragility of employability: a dynamic perspective and examples from the Netherlands. In J. Vuori, R.H. Price, \& R.W.B. Blonk (Eds.), Sustainable working lives: managing work transitions and health throughout the life course (pp. 187-214). Dordrecht (NL): Springer Science and Business Media. 
'Sustainable employability' goes one step further by focusing on retaining meaningful and challenging work, on changes over time in people and jobs such as changes in employees' motivation or changes in the skills and physical and cognitive capacities demanded on the labour market. One way of understanding sustainable employability is to consider the factors that make someone's employability less sustainable, or fragile. One of the most important factors in this regard is lack of proper education. Studies have shown that less educated employees are relatively often in temporary jobs with little job security and that, on average, less educated employees tend to be less healthy and more likely to have chronic disorders that have a detrimental effect on their employability. Also, they are ill more often and for longer periods, often leading to a premature exit from the labour market (Nicoletti \& Peracchi, 2001; Phillipson \& Smith, 2005; Henkens et al., 2009). In addition, especially those who lack proper education have a human capital disadvantage that is increasing during working life because both employers and the employees themselves invest less in the human capital of less educated employees (Heckman, 2000; Fouarge, 2009; Ester \& Kerkhofs, 2009). A lack of proper education is therefore one of the indicators of a relatively fragile employability. However, lack of education does not necessarily make the employability fragile. And the reverse is also true: education is no guarantee for sustainable employability. For instance, many employees with a basic qualification (ISCED 2) are now in jobs that are bound to change in the next few years, some even drastically. Relatively fragile employability is also a feature of these groups of working people. Therefore, we detect both causes for fragile employability in inadequate or poorly matching education, as well as in the changing employment structure and successive waves of technological and organizational change in and around work. These factors lead to constant shifts in the demand for knowledge and skills. Gaining a qualification is merely a first step towards sustaining employability. Maintaining both qualification (skills) and motivation throughout one's career is at least as important in rendering employability sustainable.

In this chapter, we introduce a dynamic perspective on sustainable employability, identifying two 'mechanisms' that exacerbate the fragility of a person's employability, and highlight the importance of maintenance. These mechanisms are skills mismatch, which involves mismatches in the course of a career between what employees are able to do and what the job and the labour market demands; and motivation mismatch, which involves mismatches in the course of a career between what employees seek to get out of their work and what the work gives them. With these mechanisms in mind, we discuss three main routes in sustaining employability: development, mobility and work redesign and raise the following four questions:

1. What is the distinction between fragile and sustainable employability from a dynamic perspective? 
2. What are the threats to sustainable employability in terms of skills mismatch and motivation mismatch?

3. Which routes are available in sustaining employability in terms of 'restoration' and 'maintenance' of skills and motivation?

4. Which potentially successful interventions are associated with these routes?

Current HR management practices seem to focus more and more on the humanisation of work, giving more attention to employees' needs in their work and assuming this attention will also increase worker productivity. In academic research, these notions have been incorporated in theories such as Hackman and Oldham's job characteristics model and job design theory (1976), identifying essential building blocks of work that give value to work for employees and subsequently lead to lower rates of sickness absence and better work performance. Over the years, knowledge about how to design healthy and productive work has been enhanced with insights from the stress and burnout literature (Karasek, 1979; Maslach, Schaufeli \& Leiter, 2001), the team and sociotechnical literature (De Sitter, 1994), and the medical and ergonomic literature (Campion et al., 2005; Humphrey, Nahrgang \& Morgeson, 2007). The quest for the optimal arrangement of workplace and work processes has proceeded along various lines. The fundamental assumption throughout is that compliance with certain design requirements and norm values will render the quality of work transparent. Fine tuning, supplementary policy and redesign are assumed to add quality to work and achieve a better person-job fit, with all the attendant benefits for absenteeism, productivity and employability (see also Grant \& Parker, 2009). Nonetheless, there appears to be no clear-cut relationship between the quality of the work and the outcomes for employees (e.g. for health, motivation and employability) and employers (e.g. for productivity, absenteeism and turnover).

The literature puts forward two explanations for the lack of this clear cut relationship:

1. Individual differences between employees: employees' opinions differ on aspects of their work; what one person finds varied or heavy work may be perceived quite differently by someone else;

2. Time-related differences: employees might respond differently in the course of time to the same work characteristics; i.e., what an employee considers to be varied or heavy work may change over time.

The differences between individual employees and the changes in the perception of work over time may be viewed as criteria for assessing the quality of work in terms of a good person-job fit. Research into this person-job fit (Kristof, 1996) identifies two types of 'fit' or 'match': 
1. The match between what the work demands and what the employee is capable of (i.e. the demands-abilities (D-A) match);

2. The match between what the employee wants or values and what the work provides (i.e. the supplies-values (S-V) match).

Kristof (1996) assumes that a D-A match or mismatch has a stronger relationship with health and performance indicators, while an $\mathrm{S}-\mathrm{V}$ match or mismatch has a stronger relationship with motivational aspects and attitudes to the work and the organization. With that, Kristof's dynamic concept of D-A match or mismatch strongly resembles Jovanovich's earlier Job Matching Theory (JMT: Jovanovich, 1979). Employees may be perfectly capable of coping with the demands of their job, yet not find the work actually meaningful. On the other hand, the work may match well with personal values (such as attaching importance to providing excellent patient care), while the employee is no longer able to meet the cognitive, emotional or physical requirements of the job (lifting patients, dealing with new medical technology). When recruiting, employers will assess whether the job matches both a candidate's knowledge and skills and his or her motivation. But employees will also assess whether the work being offered matches their knowledge, skills, interests, values and financial and other needs. This is the first point at which mismatches can be avoided, and if there is any doubt on a proper match there is always the option of a trial period or a temporary contract. Mismatches may arise in time for a variety of reasons as a result of changes either in the job or on the part of the employee.

From this perspective, an employee is sustainably employable when what the work demands and provides matches with what the employee is able and willing to deliver, and when the employee is capable of protecting and maintaining this match over time, using current information about developments within and around the work. In my view, sustainable employability is explicitly about a dynamic match between work and employee, in which employees continue to be optimally employable despite changes in the person, job demands, or employment situation. This approach also concurs with Van der Klink et al.'s (2011: p. 347) definition of sustainable employability: 'Sustainable employability means that throughout their working lives employees have access to actually achievable opportunities and conditions needed to continue to perform their current and future work while preserving health and wellbeing. This implies a work context that facilitates them in doing so, as well as an attitude and motivation to actually exploit the opportunities at hand'. 
With this dynamic approach three dimensions of (mis)match are distinguished for assessing employees' sustainable employability over time. The 'demands-abilities' (D-A) dimension of (mis)match reflects the concept of skills (mis)match. Skills mismatch occurs when the demands in the work on physical and mental capacity or knowledge and skills do not, or no longer, match an employee's physical and mental capacity and knowledge and skills (D-A mismatch). The 'supplies-values' (S-V) dimension of (mis)match reflects the concept of motivation (mis)match. A motivation mismatch occurs when the job does not, or no longer matches an employee's workrelated or other values and needs (S-V mismatch) ${ }^{2}$.

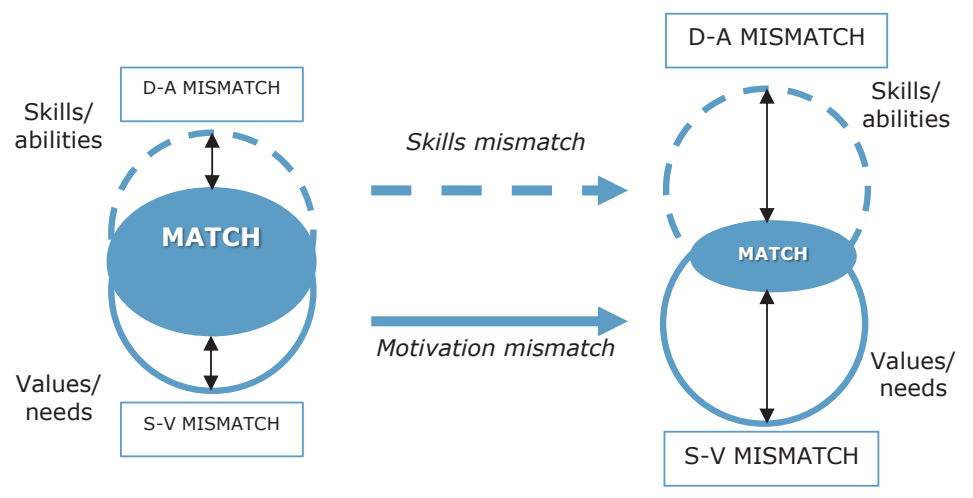

Figure 2.1 Skills and Motivation (Mis)matches

Figure 2.1 shows the dynamic person-job match theory with respect to the processes of skills and motivation mismatch. In the first situation (left hand figure) there is a satisfactory match between what the work demands or provides and what the employee is willing and able to do. In the second situation (right hand figure) it would appear that as time passes the employee sees his or her needs and values reflected ever less in the work, which may arise from the nature of, or changes in, either the work or the employee. The figure also shows that both the processes of skills and motivation mismatch make work 'match' less good with the employee's skills, abilities, values and needs. An employee loses 'employability'.

\subsection{Understanding skills mismatch}

Following Kaufman (1989), Neuman \& Weiss (1995); Van Loo et al. (2001); De Grip et al. (2002) and others (for a complete review see Sanders \& Kraan, 2013), we refer to the process in which a mismatch arises between the physical capacities or the knowledge and skills that a person

2 In the empirical chapters of this dissertation I will focus on D-A (mis)fits. I will refer to these using the terms 'skills match or skills mismatch'. 
provides, and the capacities and knowledge and skills that a job demands, as 'skills mismatch'. A person's set of knowledge and skills gradually loses its labour market value, because it can be brought into play ever less productively. Neuman and Weiss (1995) distinguish between technical and economic skill mismatches.

\subsubsection{Technical skills mismatches}

Technical skills mismatches occur as a result of the depreciation of human capital attributable to changes in or around employees themselves. It emerges when a person simply loses his or her command of certain skills, such as physical or mental capacities (wear), or because, temporarily or permanently, available skills are used insufficiently, or not at all (atrophy). A technical skills mismatch is also referred to as an internal depreciation of human capital.

\subsubsection{Economic skills mismatch}

Economic skills mismatches are concerned with a depreciation of human capital caused by external changes (external depreciation of human capital). Economic skills mismatches may therefore occur because of a range of technological and organizational developments. Following De Grip and Van Loo (2002), three forms of economic skills mismatch can be distinguished: Jobspecific, which sets in when the skills that are required for certain jobs change, and may eventually lead to people in the job no longer being able to satisfy the changed job requirements, either because of a lack of new skills that are now in demand and/or because of a surplus of skills no longer needed to satisfy the changed job requirements.

The second form of economic skills mismatch occurs when there is a decline in demand for certain skills on the labour market as a whole, i.e. shrinking employment in a particular sector of industry, and may be referred to as skills mismatch by changes in the structure of employment. An often-used example is the high unemployment rate in the province of Limburg following the closure of the coal-mines. The knowledge and skills once needed in the mines appeared to have little value in other sectors of the economy.

Finally, employed people are sometimes obliged to change firms, having been made redundant because of developments at company level. Reorganizations and job cuts may entail dismissals. In this case the firm-specific human capital an employee possesses (such as knowledge of specific equipment, procedures or networks) partly or entirely loses its value: firm-specific skills mismatch. 


\subsection{Three routes in sustaining employability}

Sustainable employability appears to be a complex interaction between what employees want and are able to do in their work, and what is still, or possibly no longer, provided and demanded. From the perspective of a dynamic person-job match, both the mechanisms of skills mismatch and motivation erosion lead to an increasing risk of mismatch and a more fragile instead of sustainable employability. In the terminology of the 'fit' literature, the HR perspective on sustainable employability is mainly concerned with managing the mechanisms of skills and motivation mismatch and recover an optimal person-job match.

In this thesis I focus on three 'routes in sustaining employability':

1. Development: match recovery by employee (and employer) who adapts to work by developing own skills set through education and training (learning new skills);

2. Mobility: match recovery by employee (and employer) who adapts work and employee by changing jobs internally or externally (job-to-job mobility);

3. Work redesign: match recovery by employee (and employer) who adapts work or conditions of employment to own skills (cushioning or utilization).

These three 'routes' can each be effective. Figure 2.2 visualizes the three routes in sustaining employability that, in theory, help restore skills (and motivation) match.

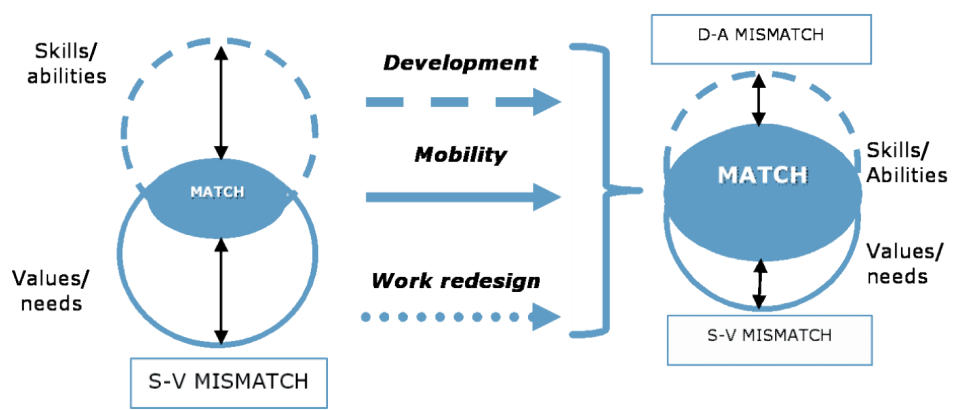

Figure 2.2 Three routes in sustaining employability

\subsubsection{Development}

The first route in sustaining employability targets actions for employees who are at risk of falling behind in terms of knowledge and skills. Activities on this route such as on the job instructions, training or education help employees keep their skills up-to-date so they can keep up with changes in skills demands now and in the future. This route also relates to the choice employers make to continuous investments in training in order to attract and retain well-qualified employees. These training investments will be mainly aimed at preventing skills shortages that employers or 
employees expect or at recovering from these skills shortage. The development route does not, however, only focus on the maintenance or development of knowledge and skills through instructions or training on and off the job in courses or workshops and through promoting a learning culture, providing individualized learning solutions or taking part in substantial educational programs. It also focusses on preserving mental and physical fitness, through measures such as policies on working conditions, working attitude and safety culture. An important fundamental idea in this development route is that permanent physical, mental and cognitive development contributes to making employability more sustainable. Self-management is often an important vehicle for this development route. Self-management enables the employee to retain as much control as possible of remaining his or her sustainably employable. Self-direction in the work context is defined as 'a characteristic adaptation to influencing processes in the working life in the interests of individual self-reliance on the labour market' (Raemdonck, 2006: p. 62). In line with the emphasis on life-long learning, many studies focus on 'self-directed learning' (Raemdonck, de Grip, Segers, Thijssen, \& Valcke, 2008). Self-direction in learning is about taking personal initiative to undertake formal and informal learning activities leading to the achievement of specific learning objectives, that meet the changing work requirements. Some examples are participation in training courses, workshops, knowledge sharing with co-workers, and searching for and interpreting information related to the discipline concerned. Research has shown that participation in learning activities helps to make employability more sustainable (De Grip, van Loo \& Sanders, 2004; Raemdonck et al., 2008; Van der Heijden et al., 2009a), especially when a learning activity is a 'positive experience' (see also Chapter 5 of this dissertation). In practice, however, training participation among less educated and also older employees is increasingly lagging behind that of higher educated and younger employees (Fouarge et al., 2013; Sanders, Keijzer, Van Wijk \& Geuskens, 2011a), while Raemdonck (2006) shows that less educated people exhibit little self-direction in learning. However, in contrast, a multivariate analysis shows that workers' educational level as such is not related to the degree of self-direction in learning and career. Other factors, such as performing knowledge work, being given learning opportunities, and aspirations for mobility, appear to be stronger explanatory variables. Accordingly, research by Sanders, Oomens, Blonk and Hazelzet (see also Chapter 3 of this dissertation) shows that the intention of less educated people to participate in education or training partly depends on the support they receive from co-workers and management. The latter contributes to a culture of learning in which participation in education or training is valued. Therefore, it is not so much educational level or age that leads employees to focus on their development, but it seem to be environmental factors that play an important role. In Chapters 3 and 4 of this dissertation I aim to find out which factors are the most important drivers of workers' skill development. 


\subsubsection{Mobility}

The second route in sustaining employability is mobility. The mobility route assumes voluntary internal or external mobility, as a way of sidestepping a mismatch with the current job, and of pursuing a better person-job fit matching one's skills to a different job. Employees are mobile in order to find a better use for their current skills rather than to change their skills profile by further training. A transition to a different job, department, organization, or industry, is initiated in response to (the threat of) reduced work volume in the future or a declining use for the skills set an employee possesses.

Typical activities in the mobility route are promotion (upward mobility) or demotion (downward mobility), outplacement, horizontal mobility and multi-jobbing, where one takes on a second job or becomes part-time self-employed to make better use of one's skills set. Employees who possess the capacities and motivation to take the mobility route are considered more employable. To foster mobility, an organisation can start preparing its employees at an early stage for different jobs or tasks inside, but maybe also outside, the current organisation. The scale of voluntary mobility among older and less educated employees is, however, relatively modest (Gesthuizen \& Dagevos, 2005; Vandenbrande, Coppin, van der Hallen, Ester, Fouarge, Fassang, Geerdes, \& Schömann, 2006; Zwinkels, Ooms, \& Sanders, 2009). Nauta et al. (2005) had already shown that as employees age their assessment of the opportunity to find an attractive new job with a different employer declines substantially. A lower educational level reinforces this effect. The mobility route is thus pursued only to a very limited extent. In Chapter 5 of this thesis I analyse how less educated (older) employees can be stimulated to take the mobility route in sustaining employability.

\subsubsection{Work redesign}

The third route (work redesign) involves adjustments in the current job in order to align the job better with the employee's needs, strengths and capacities, when a skills mismatch is likely to occur. Adjusting the nature of a job to an employee's skills and motivation might ensure that this job continues to match the employee's skills and motivation which allows for making better use of what an employee is able and willing to do. Work redesign may refer to 'downward adjustments' of the job tasks, in which the job is trimmed back, for instance by giving an employee fewer tasks, more time to perform tasks or more resting-time in between tasks. These so called 'cushioning strategies' are often used by employers to unburden older employees. These policies carry the risk of trimming away features of a job that these employees have always considered a valuable aspect of their job. Downward adjustments therefore may bring the risk of inducing motivation mismatch. Work redesign may also involve upward adjustments however. These 'utilization strategies' aim to make a job more challenging by adding tasks or complexity so that employees 
can use more of their skills. A utilization strategy is oriented to job development and work redesign with the goal of productively, healthily and sustainably embedding the employees in the current job and the current organisation.

A utilization route in sustaining employability envisages better utilization of employees' skills in order to keep the current job interesting, while also improving or at least preserving workers motivation for their job (i.e., prevent skills and motivation mismatch). Work redesign may focus on changes in the current task (job enlargement, job enrichment, changing role) or workday design (independent task planning, flexible work schedules). For older employees, stagnation in job development, where the routine nature of the current work is accompanied by a loss of meaning and challenge, appears to be a more important predictor of job dissatisfaction than the lack of vertical career development. Kooij (2010) asserts that this argues for a sharper focus on upward adjustments as a fruitful route to sustainable employability, also for less educated employees. Upward adjustments, however, do carry the risk of adding features to a job that employees may consider too complex of challenging. Upward adjustments, therefore, may bring the risk of inducing a (temporary) skills shortage rather than reducing it, rendering work redesign a counterproductive strategy in sustaining employability. However, since Ybema et al. (2009) find that flexibility in structuring employees' own working hours (workday design) has an important effect on the assessment of their own capability to remain at work until the age of 65 , since Rau and Adams (2005) show, in an experiment with various recruitment texts, that older employees are more likely to apply for a job that combines mentoring duties with opportunities for flexible working hours, and since work redesign prevents the organization from losing neither the knowledge and experience nor the internal and external networks that have been built up, we are convinced that the work redesign route offers interesting opportunities for making employability more sustainable, mainly for older and less educated employees. In Chapter 6 of this thesis, I explore possibilities for redesigning less educated older employees' work.

\subsection{Conclusions}

This chapter has defined sustainable employability as the dynamic process of maintaining the match between what an employee is able and willing to do (skills, abilities and motivation) and what work demands and provides (skills, abilities and motivators). Individual employability is more or less constantly fragile as a consequence of skills mismatch and motivation mismatch. A skills mismatch implies a mismatch between the skills and abilities required for a job and those an employee possesses. Skills mismatch may involve skills shortage or knowledge deficits, which occurs when employees do not or no longer have the skills required for their current job. 
The perception of skills shortage and the routes to prevent or resolve it are the focus of this thesis. Skills mismatch may, however, also involve a skills surplus, occurring when employees possess more skills than their current job requires. The perception of skills surplus is, however, not the focus of this dissertation. The same holds for the mechanism of motivation mismatch, which implies the emergence of a mismatch between what motivates an employee and what work provides. Sustaining employability involves targeted strategies for continued '(self) matching' of available skills to the skills that are in demand in order to prevent a skills shortage.

For this (re)matching process we identified three possibly fruitful 'routes': development, mobility and work redesign. The development route is concerned with education, training and developing the employee's skills set in a way that the skills that a job requires (or will require in the future) are developed. Interventions in the development route could take the form of both formal and informal learning. The mobility route is concerned with reallocating a worker's human capital in the organization (internal) or on the external labour market with the goal to better match a worker's skills to the skills demanded in his or her job. The mobility route includes all forms of internal and external mobility, both horizontal and vertical and both upward (promotion) and downward (demotion) and mixed forms, such as combining tasks from two or more jobs. The work redesign route is concerned with the optimal use of a worker's skills set through the redesigning of tasks and work processes. Interventions in the redesign route for instance may include job enlargement, job enrichment, task variety, task reductions and job carving.

Development, mobility and work redesign are routes to improve the skills match between workers and their jobs, and therefore to sustain workers' employability. The route likely to be most fruitful for a given person depends on why that person's employability is fragile in the first place. An open dialogue within the employment relationship is of great importance in obtaining and retaining a (good) match between employees and their jobs. For less educated (older) employees this may require some emancipatory action, since these groups appear to be underrepresented on all three routes. 


\section{Development}




\section{Chapter 3: Explaining less educated employees' training intentions $^{3}$}

\subsection{Introduction}

The working population in the industrialized countries is gradually greying (European Commission, 2008). This development gives rise to much debate on how to extend people's work-life and on how to increase labour participation and productivity (Peterson, 1999; Dychtwald, 2006; Phillipson \& Smith, 2005; Proper, Deeg \& Van der Beek, 2009). For a number of reasons less educated employees deserve special attention in this debate.

First, the less educated run a higher risk of not having the skills, knowledge or abilities needed to extend their productive period in the labour force. In 2010, nearly two million Dutch people were reported to be 'lower' educated, meaning that they did not possess a ISCED-2 level education (Statistics Netherlands, 2010). In order to remain a strong knowledge-based economy in which employers have access to a strong and well-educated labour force, this number needs to go down, as agreed upon in the Lisbon Accords in 2000.

Second, less educated employees are more often in precarious jobs than intermediate and higher educated employees. They more often work in temporary jobs, physically more demanding jobs and in jobs with less job security and less financial security (De Grip et al., 2002; De Vries, Wolbers \& Van der Velden, 2004; Salverda, 2011). This decreases the possibility for less educated employees to extend their active and productive work-life until the age of 65 , not to mention 66 or 67 .

Third, less educated employees are more often less healthy, partly because of chronic illnesses, leading to more short-term or long-term career interruptions, sickness absence (Nicoletti \& Peracchi, 2001) and a further weakening of their labour market position, especially in the long run. Research has shown that less educated employees have a higher risk of becoming unemployed and also of staying unemployed for longer periods of time (Gesthuizen, 2008).

Moreover, they face the risk of being crowded out of the low-skilled jobs by intermediate and higher educated employees (Gesthuizen \& Wolbers, 2011). Concurrent with the duration of periods of inactivity, either because of sickness or because of unemployment, certain skills may get lost, when not used or further invested in. In economic literature this process is called atrophy,

3 This chapter is based on: Sanders, J., Oomens, S., Hazelzet, A., \& Blonk, R. (2011). Explaining lower educated worker's training intentions. Journal of Workplace Learning, 23, 402-416. 
or 'forgetting' (De Grip \& Van Loo, 2002). Skill mismatches occur when the human capital of a person in a given job becomes incongruent with the skills required for that specific job (Fossum, Arvey, Paradise, \& Robbins, 1986; De Grip \& Van Loo, 2002). More and more, predominantly technological changes in and around the workplace cause an increasing demand for higher skill levels, leading to a rising risk of present skills becoming obsolete, especially when employees are regularly away from the workplace, as is the case for less educated employees (Bartel \& Sicherman, 1993; De Beer, 2006; Van Genabeek \& Wevers, 2009). Clearly these higher risks of skill obsolescence for less educated employees may increase their risk of both economic and social marginalization (De Beer, 2006; Gesthuizen, 2008).

These considerations make clear that for the less educated investing in human capital is crucial to remain attractive for the labour market. There is however a vast body of research indicating that less educated employees lag behind in terms of training participation. Bassanini, Booth, Brunello, de Paola and Leuven (2005) showed that this holds for most industrialized countries, and Fouarge, et al. (2013) and Ester and Kerkhofs (2009) showed this specifically for the Netherlands. Although training participation rates among less educated Dutch employees have increased in the last decades, this increase is considerably smaller than the average increase in training participation of all Dutch employees in that same period (Fouarge et al., 2013). In the Netherlands, therefore, the training participation gap between less educated employees and intermediate and higher educated employees has been widening (Fouarge et al., 2013). As a consequence, the already precarious labour market position of less educated employees could further weaken. The issue of a lagging training participation among less educated employees has recently been addressed by policymakers as well as scholars. Attempts to explain the persisting (and growing) gap in training participation between higher and less educated employees remain, however, relatively scarce. The few studies on training participation that include less educated employees show that less educated employees' intrinsic motivation to participate in training is significantly lower than that of higher educated employees (Tharenou, 2001; Knud, 2005; Fouarge et al., 2013). All three studies indicate that negative experiences in school are the main cause for not participating in training. Fouarge et al. (2013) have recently shown that a lower intrinsic motivation among less educated employees is mainly explained by differences in noncognitive skills, such as someone's conscientiousness, locus of control, orientation on the future, differences in perceived costs aspects of training and the psychological costs (exam anxiety). This study builds on these findings by analysing the personal as well as contextual factors that increase less educated employees' intrinsic motivation to participate in training.

Main research question is: What personal and contextual factors affect less educated employees' intentions to participate in training? 
This chapter proceeds as follows. Section 3.2 briefly discusses Fishbein and Ajzen's theories of reasoned action (TRA) and planned behaviour (TPB) as a theoretical framework for studying less educated workers' training intentions and training participation. From this literature eight hypotheses are derived. Section 3.3 describes data, method and variables used to test these hypotheses. Section 3.4 presents the estimation results and section 3.5 concludes.

\subsection{Theoretical background and hypotheses}

\subsubsection{Theories of planned behaviour and social cognitive theory}

A powerful framework for studying motivational and contextual factors that influence employees' intention to participate in training is provided by Fishbein and Ajzen's (1975): Theory of Reasoned Action (TRA). TRA states that one's intention to participate in educational training is the proximal determinant of actual participation in training. The intention to participate in training, in turn, is influenced by one's attitude toward training and one's subjective norm toward training. One's attitude toward training is the individual sum of advantages and disadvantages of training participation. This subjective norm refers to the perceived expectations or pressure of important others with regard to one's participation in training and the willingness to fulfil these expectations and pressures. The more positive the attitude and the more a person has been pressured to participate in training, the more motivated an individual will become to participate in training. Ajzen $(1985,1991)$ expanded TRA into the Theory of Planned Behaviour (TPB) by introducing the construct of perceived behavioural control in order to improve TRA predictions in nonvolitional contexts. The concept of perceived behavioural control is similar to the concept of selfefficacy, introduced earlier in Bandura's social cognitive theory (1982).

Perceived behavioural control refers to the extent to which an individual expects to have control over performing the required behaviour, or the ease with which that behaviour can be performed (Sutton, 1998). In the case of the intention to participate in training, perceived behavioural control would refer to the perceived ease with which an individual would participate in a training activity. Although decades of applied TRA and TPB research have proven TRA and TPB to be useful frameworks to predict participation in organizational training (Fishbein \& Stasson, 1990; Borghans, 2006), managerial development activities (McCarthy \& Garavan, 2006) and employee development activities (Colquitt, LePine, \& Noe, 2000; Tharenou, 2001; Hurtz \& Williams, 2009), TRA and TPB research specifically aiming at less educated employees and their training participation is scarce (Millar \& Shevlin, 2001; Tharenou, 2001; Renkema, 2006). Among the few studies that were published on the subject, Renkema (2006) showed that a less educated employee's decision to voluntarily participate in training is not a rational decision, but a combination of the psychological factors of Ajzen's TPB, namely attitude, subjective norm and 
perceived behavioural control. Building on Renkema's (2006) findings as well as on Fouarge et al. (2013) we use Ajzen's TPB as an initial framework to explain less educated employees' intentions with respect to training. We therefore hypothesize that less educated employees who have a more positive attitude as well as a stronger subjective norm and who perceive more behavioural control, have a higher intention to participate in training.

Hypothesis 1a: Less educated employees who have a more positive attitude toward training, will have a higher intention to participate in training.

Hypothesis $1 \mathrm{~b}$ : Less educated employees who have a stronger subjective norm toward training, will have a higher intention to participate in training.

Hypothesis 1c: Less educated employees who perceives more behavioural control for training, will have a higher intention to participate in training.

Apart from the three TPB-factors mentioned above, five additional factors are included, namely: career orientation, informal learning, job insecurity and management and co-worker support. In the following subsections we present theoretical arguments for the inclusion of these additional factors.

\subsubsection{Career orientations}

Career orientation is the degree in which an individual is working toward career goals in a more or less strategic manner. We suggest that an individual's career orientation is a predictor for training intentions based on Locke's goal setting theory (Locke, 1996). Goal setting theory hypothesizes that setting goals will lead to better planning and better implementation of strategies. A stronger career orientation may stimulate less educated employees to plan and implement training as part of a career building strategy. Furthermore Colquitt et al. (2000) show that motivation to learn is strongly dependent on the presence of career planning and career exploration strategies and Fouarge et al. (2013) recently reported that less educated employees who have a stronger career orientation also have stronger intentions to participate in training. On the basis of this literature we hypothesize that less educated employees who set goals in their careers and thus show more career orientation, will also show higher training intentions, mainly in order to reach those career goals.

Hypothesis 2: Less educated employees who show more career orientation, will have a higher intention to participate in training. 


\subsubsection{Informal learning}

Informal learning is the degree in which an individual learns from every day experience, in work or life, rather than from formal schooling or participating in formal courses and training. Recent employee development models (Maurer 2001, Garofano \& Salas 2005; Hurtz \& Williams 2009) are dynamic models that describe employee development as an ongoing process, in which development episodes in the past are precursors to employees' current and future intentions and actions. In their extensive review article on TPB, Conner and Armitage (1998) also showed that past behaviour, on average, explains $7.2 \%$ of the variance in the intention to show the same behaviour in the future. These relations have also been shown for voting behaviour (Albarracin \& Wyer, 2000) and blood donation (Kidwell \& Jewell 2003). Fouarge et al. (2013) have found that the level of informal learning indeed stimulates the participation in later learning activities. However, for less educated employees the relationship between informal learning and intentions with respect to training has not been studied thus far. Based on the above findings we expect that past and current informal learning activities may stimulate less educated employees' intentions to participate in training.

Hypothesis 3: Less educated employees who participate in informal learning activities, will have a higher intention to participate in training.

\subsubsection{Job insecurity}

Job insecurity is the degree in which an individual feels at risk of losing his or her current job position. As indicated before, less educated employees are less certain of their job or labour market position in general than intermediate and higher educated employees (Borghans \& De Grip, 2000; Gesthuizen, 2008). According to the screening hypothesis (Thurow, 1970) employers always opt for the best educated employee in the queue of labour supply to the firm. We therefore expect that the degree of job insecurity may affect employees' confidence whether they have the necessary skill level or skills for the job, currently or in the future. Employees may feel that they are 'moving to the back of the employer's preference queue'. In order to move to the front of the queue again and reduce the risk of job loss, taking part in training will be considered as a useful strategy. We hypothesize that less educated employees with a higher level of job insecurity, will be more motivated to take up training activities in order to prevent job loss.

Hypothesis 4: Less educated employees who experience higher levels of job insecurity, will have a higher intention to participate in training. 


\subsubsection{Management and co-worker support}

Finally, we expect that the degree of support provided by management and colleagues in the workplace acts as a driver for less educated employees' intentions to participate in training. Colquitt et al. (2000) and Renkema (2006) both showed that these two levels of support are the main factors that influence less educated employees' intentions to participate in training. These results concur with earlier findings by Maurer and Tarulli (1994) who found that management and co-worker support are the best predictors for training participation. Based on these findings we hypothesize that less educated employees who receive more support from management and coworkers are also more likely to have plans to participate in training.

Hypothesis 5a: Less educated employees who receive more management support, will have a higher intention to participate in training.

Hypothesis 5b: Less educated employees who receive more co-worker support, will have a higher intention to participate in training.

\subsection{Method}

\subsubsection{Data, participants and procedure}

The present study used data from the Study on Life Long Learning and Employment, a study among less educated employees in the Netherlands. The survey covers a sample of less educated employees of two large national, private enterprises and one company providing employment to people with disabilities (sheltered employment firm). In our study, a less educated employee is defined as an employee with no education, only primary education, or lower secondary education (ISCED $\leq 2)$. For this article, we use data from 213 respondents $(40 \%$ of the total sample of 513 respondents) who fall within the inclusion criteria mentioned, being less educated and not having taken part in a training course in the six months prior to the survey. Table 3.1 briefly describes the total sample.

Table 3.1 Descriptive results

\begin{tabular}{|c|c|c|}
\hline & $\mathbf{N}$ & $\%$ \\
\hline Less educated, no current or recent training (Target Group) & 213 & 42 \\
\hline Intermediate or higher educated & 189 & 37 \\
\hline Less educated, current or recent training & 86 & 17 \\
\hline No information/missing information & 25 & 5 \\
\hline Total & 513 & 100 \\
\hline
\end{tabular}


Data were gathered using a written questionnaire, especially designed for the less educated target group. This questionnaire was co-designed with "Eenvoudig Communiceren", a publishing company specializing in "Simple communication". Moreover, in one of the three organizations, researchers were physically present when respondents filled out the questionnaire, enabling direct clarification on remaining questions. Some illiterate respondents had the questions and answers on the questionnaire read out load to them.

\subsubsection{Measures}

The intention to participate in training was measured by a five-item scale. Two items in this scale measured the intention to engage in training within one year. The other three items measured the current intention to engage in a training. The five-item scale combines these into one score for the intention to participate in training. Example items are "I think about taking part in a training course within the next year (Medium Term Intention)" and "In the last four weeks, did you talk to your supervisor about taking part in a training course". Responses were scored on a five-point Likert scale ranging from (1) completely disagree to (5) completely agree. The Cronbach's alpha for the Intention scale was .96, indicating a very high degree of internal consistency.

In this study, we combined a two-item general affective attitude scale and a two-item expectancyvalue attitude or 'valence' scale. Fishbein and Stasson (1990) found a strong correlation between affective and expectancy-value attitudes. Since we also found relatively strong correlations between the two $(r=.534)$ in our study, we decided to combine the two subscales into one four item attitude scale measuring both affective and expectancy-value attitudes. Example items include: 'It is nice to follow a course' and 'It is important to participate in training'. Responses were scored on a five-point Likert scale ranging from (1) completely disagree to (5) completely agree. Cronbach's alpha for the attitude/expected value scale is .84 .

The term subjective norm refers to the perceived expectations or pressure of important others with regard to one's participation in training (Ajzen, 1988). Subjective norm or social pressure was measured with two five-item subscales. The first subscale consists of items on how important one's partner, children, parents, friends and colleagues find participation in training for the respondent. Response options ranged from (1) 'not important at all' to (5) 'very important'. With a Cronbach's alpha of .82 this subscale for subjective norm is considered highly internally consistent. The second subscale also consists of five items asking the respondent to rate the importance of the opinion of the respective important others (partner, children, parents, friends and colleagues). Again, response options ranged from (1) 'not important at all' to (5) 'very important' (Cronbach's alpha $=.90)$. The subscales for opinion and the importance of that specific opinion were then combined to create one scale for subjective norm, with scores ranging from (1) 
'no pressure' to (5) 'a lot of pressure'. The internal consistency for the combined scale is also very good, Cronbach's alpha being .88.

Perceived behavioural control was measured with a five-item self-efficacy scale, originating from Ellis and Taylor (1983) and Van Ryn and Vinokur (1992). The scale was adapted specifically for the purpose of measuring people's pre-training self-efficacy. Example items include: 'I am sure I shall be a good student' and 'I am sure I am able to successfully take a course'. Response options ranged from (1) 'completely disagree' to (5) 'completely agree' (Cronbach's alpha =.94).

Career orientation refers to the degree in which an individual is planning his or her career. The concept of career orientation is measured with a five-item scale. This five-item scale is an adaptation of the six item 'exploration of vocational issues' scale by Kracke (1997). After careful consideration one item of the scale Kracke used was excluded for this study, namely: 'I consider various occupations and try to get extensive information about all alternatives'. It is considered an item that is too complex for our target group of less educated employees. Answering categories range from (1) 'Strongly agree' to (5) 'Strongly disagree'. Our five-item version shows a strong internal consistency with a Cronbach's alpha of 89.

The concept of informal learning in this study is measured by a two-item scale that originates from Borghans et al. (2006), who developed the scale in order to study determinants of knowledge acquirement. The two items on the scale are: 'Do you continuously learn new things at work' and 'Do you get tasks that you can learn a lot from'. Answering categories range from (1) 'Always' to (5) 'Never'. Cronbach's alpha is satisfactory with .82.

The concept of job insecurity is measured by a three-item scale. The job insecurity scale is an adaptation of the 'chance of unemployment'-scale which was developed by Goudswaard et al. (1998). The three items used in our study are: 'Do you worry about keeping your job', 'Would you describe the future at your company as favourable' and 'Do you run the risk of losing your job'. Respondents could answer all three questions with 'yes' or 'no'. The job insecurity scale used in this study has a Cronbach's alpha of .80 making it a reliable measure.

Management support was measured using a five-item scale. This scale is a combination of the four-item supervisory support scale that has been used in the TNO Labour Situation Survey (TAS) questionnaire (see also: Smulders, Andries, \& Otten, 2001) and one added item taken from the ROA Lifelong Learning Survey (see also: Borghans, Golsteyn, \& De Grip (2006)). For example: 'My supervisor thinks the employees' well-being is important', and 'I receive feedback from my supervisor referring to my development and possibilities to grow'. Answering categories 
range from (1) 'Strongly agree' to (5) 'Strongly disagree'. The scores were recoded, so that a higher score indicates more management support. The five-item scale reports an internal consistency (Cronbach's Alpha) of .84.

The concept of co-worker support is measured by a four-item scale also taken from the TNO Labour Situation Survey questionnaire. For example: 'My colleagues help me to get the job done'. Answering categories range from (1) 'Strongly agree' to (5) 'Strongly disagree'. Again the scores were recoded, so that a higher score indicates more co-worker support (Cronbach's alpha= .70). We included the socio-demographic characteristics age and gender in our models as confounding variables. Also, since data were collected in three different companies we include a dummy variable for the organization people work in.

\subsubsection{Analysis}

I used a two-step procedure to test my hypotheses. First, we calculated bivariate zero-order correlations, including all eight predictors and the outcome measure intentions with respect to training. Next, we estimated a multiple regression model to explain differences in less educated employees' intentions with respect to training. In this model we included those independent variables that correlate significantly with training intentions and the confounding variables.

\subsection{Estimation results}

Means and standard deviations for training intentions by gender, age and organization are presented in Table 3.2 .

Table 3.2 Training intention by gender, age and organization

\begin{tabular}{|c|c|c|c|c|c|}
\hline & & \multicolumn{4}{|c|}{ Training intention } \\
\hline & & M & SD & T values & $\mathbf{N}(\%)$ \\
\hline Total & & 2.5 & 1.22 & & $209(100 \%)$ \\
\hline \multirow[t]{2}{*}{ Gender } & Male & $2.3^{* * *}$ & 1.14 & -3.650 & $151 \quad(73 \%)$ \\
\hline & Female & $3.0^{* * *}$ & 1.29 & 3.650 & $57 \quad(27 \%)$ \\
\hline \multirow[t]{5}{*}{ Age } & $16-25$ years old & $3.2^{*}$ & 1.21 & 1.764 & $(4 \%)$ \\
\hline & $26-35$ & 2.5 & 1.41 & .002 & $19 \quad(9 \%)$ \\
\hline & $36-45$ & $3.1^{* \star *}$ & 1.19 & 4.383 & $55 \quad(27 \%)$ \\
\hline & $46-55$ & 2.5 & 1.10 & -.490 & $87 \quad(42 \%)$ \\
\hline & 56 or older & $1.6^{* * *}$ & 0.77 & -5.569 & $36 \quad(17 \%)$ \\
\hline \multirow[t]{3}{*}{ Organization } & Org 1 & 2.4 & 1.19 & -.749 & $53 \quad(25 \%)$ \\
\hline & Org 2 & $2.1^{* * *}$ & 0.99 & -4.004 & $72(34 \%)$ \\
\hline & Org 3 & $3.0^{* * *}$ & 1.26 & 4.625 & $84(40 \%)$ \\
\hline
\end{tabular}

Note: Means are tested with the t-test (vertical comparisons). The contrast is each subgroup versus all other cases (weighted deviation contrast). ${ }^{*} \mathrm{p}<.10,{ }^{* *} \mathrm{p}<.05,{ }^{* * *} \mathrm{p}<.01$ : Significant high (low) mean (2-tailed tests), and Cohen's d leffect size| is at least 0.20 . 
Table 3.2 shows that less educated female employees have a significantly higher training intention than male employees. The table also shows differences between age groups. The middle-aged (age 36-45) employees have a significantly higher intention to participate in training than other age groups. The $56+$ employees are least motivated to do so, the $16-25$ year olds have the highest training intention. These findings are consistent with earlier findings by Fouarge et al. (2013).

In Table 3.3 the means, standard deviations and bivariate zero-order correlations for the eight predictors of less educated employees' intention to train are presented. The matrix shows significant positive correlations between the three personal factors that, according to the Theory of Planned Behaviour, predict less educated employees' intention with respect to training, namely attitude/expectancy values (Pearson's $r=.641)$, subjective norms $(r=.501)$ and perceived behavioural control $(r=.570)$. In accordance with our hypotheses, we also find significant positive correlations between training intentions and career orientation ( $r=.316)$, management support $(r=.172)$ and co-worker support $(r=.220)$. These are, however, weaker correlations than those found for the TPB factors. Contrary to our hypotheses, no support was found for job insecurity and informal learning practices being predictors for their intention with respect to training. These variables are therefore excluded for further analyses. 

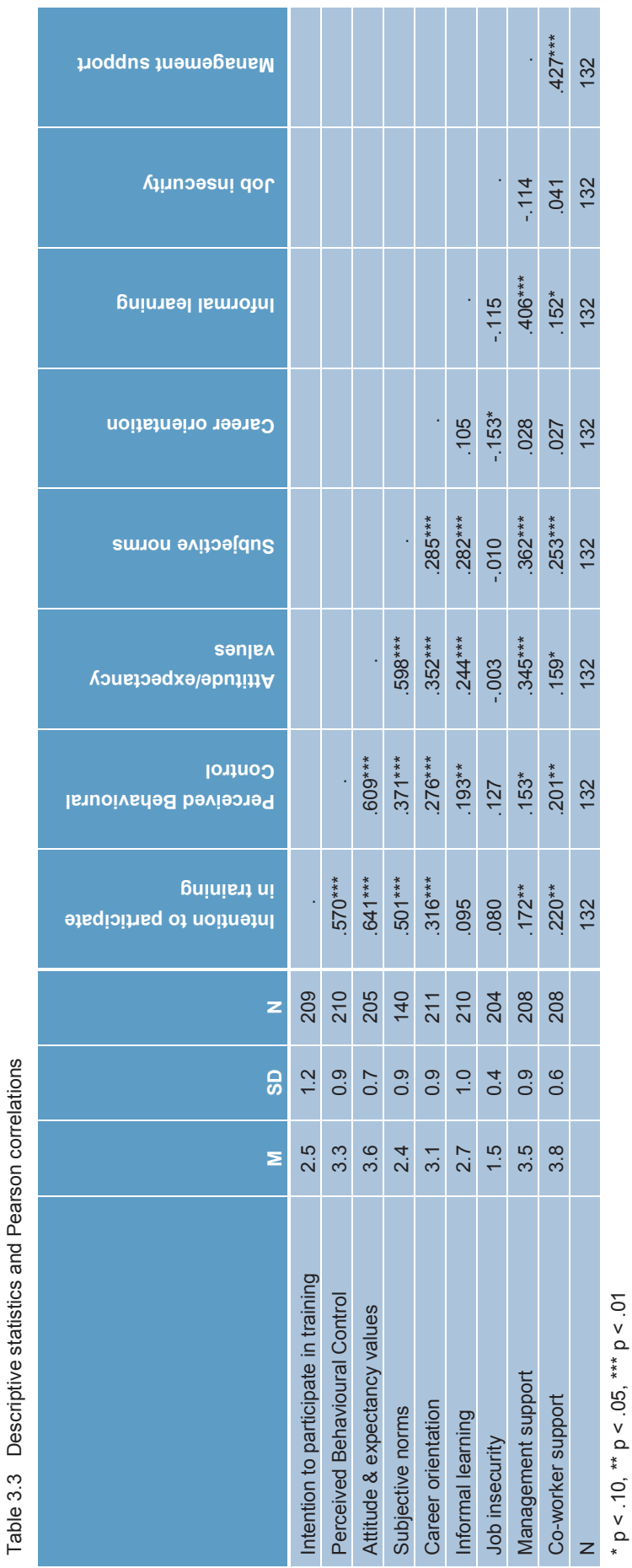
Next, the estimation results of the multiple regression analysis are presented in Table 3.4. Results show confirmation of Ajzen's TPB model and support for Hypotheses $1 \mathrm{a}, 1 \mathrm{~b}$ and $1 \mathrm{c}$, in the sense that subjective norms, perceived behavioural control and attitude/expectancy values are all positively related to less educated employees' training intentions. The multiple regression model we propose explains $55 \%$ of total variance in less educated employees' training intentions. Table 3.4 also shows that, although bivariate correlations were significant, neither career orientation, nor management or co-worker support are related to less educated employees' training intentions. Hypotheses 2, $5 \mathrm{a}$ and $5 \mathrm{~b}$ are not supported. This suggests that the relationships found between career orientation, management support and co-worker support and training intention mainly run through other factors in the multiple regression model.

Table 3.4 Regression estimates of less educated employees' training intentions

\begin{tabular}{|l|c|c|}
\hline & $\beta$ & SE \\
\hline Subjective norms & $.184^{*}$ & .108 \\
\hline Perceived behavioural control & $.338^{* *}$ & .131 \\
\hline Attitude/ expectancy values & $.696^{* * *}$ & .170 \\
\hline Career orientation & .098 & .097 \\
\hline Management support & -.098 & .115 \\
\hline Co-worker support & .160 & .158 \\
\hline Gender (female) & $.306^{*}$ & .183 \\
\hline Age & -.003 & .009 \\
\hline Org1 & $-.495^{* * *}$ & .183 \\
\hline Org2 & $-.479^{* *}$ & .207 \\
\hline Org3 & REF & \\
\hline $\mathrm{N}$ & & .51 \\
\hline Adj. $\mathrm{R}^{2}$ & & \\
\hline
\end{tabular}

${ }^{*} p<.10,{ }^{* *} p<.05,{ }^{* * *} p<.01$

\subsection{Conclusions}

The aim of this study was to examine which factors determine less educated employees' intentions to participate in training. A more profound insight in these determinants is necessary for HRD, HRM and rehabilitation professionals who are concerned with developing interventions aimed at stimulating less educated employees to enhance their own employability and skills through training. An increase in less educated employees' training participation is, however, not only necessary on the individual level in order to prolong one's productive work-life, but also on the company level for continuity and growth and on the national level for keeping social security affordable. We used the framework of the Theory of Planned Behaviour (TPB) to formulate hypotheses on which factors determine intention with respect to training. Our results show that Ajzen's theory of TPB applies to the specific target group of less educated employees and their training intentions. 
We conclude, therefore, that when designing interventions aimed at stimulating less educated employees to participate in training, there should be a clear focus on strengthening (1) their belief in being successful when participating in a training activity, (2) their attitude towards training and (3) the benefits employees' expect from participating in training.

There should also be a focus on enhancing less educated employees' subjective norms on training participation. This indicates that HR interventions aiming at less educated employees' intrinsic motivation to participate in training should take account of the perceived value that significant others, such as family and friends, as well as colleagues, attach to one's training participation. We analysed five other possible determinants of employees' training intention: career orientation, informal learning, job insecurity and management or co-worker support. Contrary to our expectations, however, we found no empirical support for a direct relationship between these predictors and less educated employees' intention to participate in training. Including all five additional determinants in our model only adds 1\%-point to the total variance explained. We do, however, find significant positive correlations between career orientation, coworker support, management support and training intentions. The fact that we find partial effects between managerial support as well as co-worker support on training intentions is in line with earlier findings by Renkema (2006). We therefore conclude that when developing interventions aimed at stimulating less educated employees' training intentions, first of all the aim should be to enhance employees' subjective norms on training participation through management and coworker support. One possible way to do this might be to actively involve those peers whose views on training participation are considered important by the employee or by the group of employees in question. Another possible strategy would be to strengthen the learning culture in an organisation through actively involving co-workers and managers. Results from additional analyses using Sobel Tests confirm that less educated employees' subjective norms fully mediate the relationship between the co-worker and/or management support they receive and their training intentions and significant initial relationships between co-worker support $(\beta=.46, p=$ $.001)$ and management support $(\beta=.43, p=.000)$ on the one hand and training intentions on the other, are both non-significant after controlling for subjective norms $(\beta=.22, p=.211$ and $(\beta=-$ $.01, p=.926)$.

Secondly, the aim should be to enhance employees' perceived behavioural control over successfully taking part in training. Again this might be done through management and co-worker support aimed at increasing an employees' belief in the fact that he or she does have the necessary capabilities to successfully partake in training. Thirdly, management support should be aimed at creating a more positive attitude toward training participation and a stronger belief in the value of training for one's future career. 
We suggest further analysis of the possible effect of managerial and co-worker support and career orientation on the relationship between training intentions of less educated employees and their actual training participation as well as further analysis of the relationship between subjective norms and management and co-worker support, because current research does not reveal whether social support is a predictor for stronger subjective norms or vice versa.

Finally, we find that working in organizations 1 and 2 (Org1 and Org2) has a negative effect on less educated employees' intention with respect to training. This points at organizational factors that affect less educated employees' training intentions. What organizational factor these are, remains unclear. Further research might focus on differences in HR policies between organizations. Recent studies by Borghans et al. (2009) and Fouarge et al. (2013), for instance, show that certain HR practices, such as the availability of personal development or career plans, performance-pay schemes, frequent work-meetings, performance interviews and feedback from managers increase employees' training participation. 


\section{Chapter 4: Are positive learning experiences levers for lifelong learning among less educated employees? ${ }^{4}$}

\subsection{Introduction}

With increasing globalisation and technological development, the need to maintain and update knowledge is constantly growing (European Union, 2010; Kyndt \& Baert, 2013). In order to keep a competitive position in the world market, it is of great importance for countries and businesses alike that employees continue their skill development (Doets et al., 2008; Kyndt \& Baert, 2013). The importance of lifelong learning is emphasized by the ageing population in most industrialised countries. Employers who fail to continuously educate their employees will weaken their competitive position in the long run. Also for employees themselves it is necessary to keep their knowledge and skills up-to-date in order to secure their labour market position (Van Dam, van der Heijden, \& Schyns (2006); Doets et al., 2008; Kyndt \& Baert, 2013). For these reasons, lifelong learning has maintained a top ranking in the European agenda in the past decades (Nieuwenhuis \& Nijman, 2008). In the so-called Lisbon objectives, targets for educational participation have been set. The objective for 2020 is that in all countries of the European Union $15 \%$ of the population between 25 and 65 years participate in some kind of training (Commission of the European Communities, 2009). As the Netherlands already reached this percentage in 2000 it has set a target of $20 \%$ for 2020 (Golsteyn, 2012). Lifelong learning is not self-evident for all employees, however. Various studies have shown that less educated employees participate less frequently in training than those who are higher educated (Hazelzet et al., 2011; Kyndt \& Baert, 2013; Tharenou, 2001). Employees are considered to be less educated when they do not have a basic qualification for the labour market, that is, when they have not attended secondary vocational education at a basic level or secondary education preparing for academic and higher profession education (i.e. ISCED 2 or up). In the Netherlands, there were about two million less educated employees in 2011, which is about a quarter of the active working population (Statistics Netherlands, 2012). Although training participation of less educated employees has been growing since 1985, this increase is smaller than the increase among higher educated employees (Fouarge et al., 2013). In the Netherlands, only $10 \%$ of the lowest educated employees (only primary school) had attended a training course in the previous two years, compared to $43 \%$ of the employees with an academic degree (Van der Stelt \& De Voogd-Hamelink, 2009). This difference in training participation is especially worrisome, because less educated employees are a vulnerable group at the labour market. As Sanders et al. (2011a) note, less educated employees

4 This chapter is based on: Sanders, J., Damen, M., and van Dam, K. (2015). Are positive learning experiences levers for lifelong learning among less educated workers? Evidence Based HRM, 3(3), 244-257. 
have a higher risk of failing to meet the increasing skill demands in the labour market; they more often work in temporary, physically demanding jobs with little job security, and they have more health problems and absenteeism than higher educated employees. Moreover, owing to the introduction of new technologies, many unskilled jobs have disappeared (Rainbird, 2000).

In short, there is an increasing tension between the low training participation of less educated employees and the growing importance of lifelong learning for the labour market position of this group. Therefore, it is crucial to better understand which factors enhance or limit these employees' participation in learning activities. Until now, research has paid limited attention to this specific group. Most studies on learning activities have focused on the learning intentions and behaviours of employees in general. These studies generally indicate that employees' beliefs about their self-efficacy for learning are an important precursor of learning attitudes and behaviours (e.g., Colquitt et al., 2000). Employees who are more confident that they are able to develop and improve career-relevant skills have been found to hold more positive learning attitudes and to more frequently engage in learning activities (Kyndt \& Baert, 2013; Maurer, 2001). Accordingly, we will focus on low educated employees' beliefs about their self-efficacy for learning (i.e. learning self-efficacy). More specifically, this study investigates the effect of learning experiences on low educated employees' learning self-efficacy. We analyse whether learning activities enhance less educated employees' self-efficacy for learning, especially when these learning experiences are positive. In the next sections, we provide the theorerical and empirical evidence on this relationship. Section 4.2 briefly discusses Ajzen's theory of planned behaviour (TPB) as a framework for this study and, based upon recent literature, we introduce two hypotheses. Section 4.3 describes the data, method and variables used to test these two hypotheses, and Section 4.4 presents the estimation results. Section 4.5 then concludes and presents the practical implications of this study as well as its limitations.

\subsection{Theoretical background and hypotheses}

Ajzen's (1991) Theory of Planned Behaviour offers a useful model for explaining training participation. According to this theory, the intention to behave in a certain manner in a specific situation plays a crucial role in predicting actual behaviour (Ajzen, 1991). Applied to training, the theory predicts that when the intention to participate in training increases, the chances of actual training participation increase as well. Longitudinal research shows that training participation is indeed largely determined by employees' training intentions (Hazelzet et al., 2011; Kyndt \& Baert, 2013; Maurer et al., 2003). Therefore, the development of a training intention is an important first step toward actual participation in training. Yet, several studies have shown that training intention varies with employees' level of education. Training intention is lower among less educated than 
among high educated employees (Fouarge et al., 2013; Greenhalgh \& Mavrotas, 1994; Kyndt et al., 2011). The Theory of Planned Behaviour also predicts that training intention, in turn, is affected by employees' self-efficacy with regard to learning. Self-efficacy is a concept from Social Learning Theory (Bandura, 1977, 1982) and is defined as judgments of how well one can execute courses of action required to deal with prospective situations' (Bandura, 1982: p. 122). Self-efficacy refers to the expectation people have about their ability to perform the desired behaviour (Bandura, 1977; Hazelzet et al., 2011). In this study, we were particularly interested in the employee's learning self-efficacy, or, as Maurer and Tarulli (1994: p. 6) write the strength of an employee's belief in his or her capability to learn at a level at or above the norm when participating in a learning or development activity'.

Various studies have supported the notion that a higher learning self-efficacy is associated with a higher learning intention (Colquitt et al., 2000; Kyndt \& Baert, 2013; Maurer \& Tarulli, 1994). The more confident employees are that they will successfully complete a training, the more they will develop the intention to participate in that training. Studies have found that this also applies to less educated employees, indicating that self-efficacy is an important predictor of training intention for this group (Hazelzet et al., 2011; Kyndt et al., 2011; Renkema, 2006). This suggests that increasing less educated employees' learning self-efficacy might be a valuable strategy for enhancing training intention and subsequent training participation. How can less educated employees' learning self-efficacy be increased?

To answer this question, one should know why self-efficacy is lower among less educated employees than among higher educated employees. According to Illeris (2006), negative school experiences are often the cause of the low learning self-efficacy and motivation among the less educated. Years of daily experience of performing insufficiently at school may lead to a reduced learning self-efficacy, and a desire to leave school and stay away from learning activities. Later in life, the intention to return to a similar learning situation will be low; owing to a low learning selfefficacy, the perceived risk of failing again will be large (Illeris, 2006; Smit et al., 2005). These observations are in line with Bandura's (1982) notion that positive learning experiences, i.e. mastery experiences, contribute to self-efficacy. Additionally, Fouarge et al. (2013) found that fear of exams had a negative effect on training intention among less educated employees. Fear of exam is closely related to low learning self-efficacy, and might be caused by negative learning experiences in the past (Fouarge et al., 2013).

In a meta-analysis by Sitzmann et al. (2008) a strong association was found between trainee reactions or their subjective evaluation of the training and affective outcomes, like motivation and self-efficacy with regard to the skills learned. However, the effect of trainee reactions on learning 
self-efficacy was not measured. Most research on learning self-efficacy has been conducted in educational settings, and has supported the importance of positive learning experiences (see Schunk \& Pajares, 2001). Less research on this subject has been done among employees. Studies investigating antecedents of employees' learning self-efficacy observed positive relationships with, among others, previous participation in training, general self-efficacy, and the estimation of one's mental abilities (e.g. Maurer et al., 2003). Therefore, it is particularly interesting to investigate the effects of a positive learning experience on the self-efficacy among less educated employees. If indeed less educated employees have a lower training intention due to negative learning experiences in the past, a new positive learning experience in the present may be an important way to trigger lifelong learning. The purpose of this longitudinal study was to investigate whether training participation and a positive learning experience lead to an increase in learning self-efficacy among less educated employees. Although the role of participation in learning activities on learning self-efficacy has been studied previously (e.g., Maurer et al., 2003), to our knowledge, the effect of a positive learning experience on learning self-efficacy among the less educated has not received much research attention yet. If training participation and a positive learning experience lead to an increase in self-efficacy, it makes sense to offer easily accessible training to less educated employees. The increased learning self-efficacy in turn can lead to a higher training intention and participation in future. In this way, a self-reinforcing process of lifelong learning may be established among less educated employees.

Two hypotheses were tested in this study. Following Maurer et al. (2003), we expect training participation in general to contribute to the development of learning self-efficacy among less educated employees:

Hypothesis 1: Training participation contributes to the learning self-efficacy of less educated employees.

Training participation is, however, a 'learning experience' that can either be positive or negative. Following Illeris (2006) and Sitzmann et al. (2008), we therefore also hypothesize that only when training participation is a positive (learning) experience, it will enhance less educated employees' learning self-efficacy. If, on the other hand, training participation was not a positive experience, less educated employees' learning self-efficacy will not change.

Hypothesis 2: Positive learning experiences contribute to the learning self-efficacy of less educated employees. 


\subsection{Method}

\subsubsection{Data, participants and procedure}

For this study, data were used from a longitudinal study by TNO that investigates ways to stimulate training among less educated employees (Hazelzet et al., 2011). At three different points of time (T1, T2 and T3) with a half-year interval, respondents were asked a number of questions. A total of 359 employees completed at least one questionnaire, whereas 267 completed two or three questionnaires. The T1 questionnaire was completed by 334 employees, the T2 questionnaire by 251 employees and the T3 questionnaire by 220 employees.

Respondents were employees of three different organizations: two private sector companies and one sheltered employment company. All respondents were less educated, that is, their level of education was not higher than basic vocational education (ISCED 2). Of the respondents in the full sample ( $N=359$ ), $78 \%$ had finished secondary school or a basic vocational education; the other $22 \%$ had only finished primary school or no school at all. Average age was 47 years (SD = $9.8)$, and average tenure was 17 years $(S D=11.0)$. On average, respondents worked 35 hours a week $(S D=6.5)$. Most respondents $(76 \%)$ were male. Of the respondents, $33 \%$ had started a training of at least six months 5 years prior to this study. Between T1 and T3, 23\% of the respondents started a training of at least six months.

\subsubsection{Measures}

Training participation was measured with one question at T2 and T3: 'In the past six months, did you start a training or education that would last more than six months?'. Participants could answer 'yes' or 'no'.

Learning experience was measured with a seven-item scale developed by Oostrum (2007) measuring employees' satisfaction with different aspects of the training, and with the training in general. Respondents could indicate their answer on a 5 -point scale $(1=$ very unsatisfied, $5=$ very satisfied). A sample item was: 'How satisfied are you with the training?' These questions were presented to employees who started training between T1 and T3. If they were completed both on T2 and T3, their score on T3 was used. Cronbach's alpha was .73.

Learning self-efficacy was measured with a five-item scale from the WorkSkills questionnaire by Hazelzet et al. (2011). Respondents could indicate on a 5-point scale to what extent they agreed with the items ( $1=$ strongly disagree, $5=$ strongly agree). A sample item was: 'I'm sure I will be a good student'. Cronbach's alpha was .93. 
Background variables included age, gender, educational level, organizational tenure, and prior training participation, being training participation in the 5 years before the start of this study (ergo, before T1).

\subsubsection{Analysis}

The data were analysed using different analyses and subsamples. In a first, preliminary analysis, several background characteristics that may affect learning self-efficacy, and actual training participation, were investigated using ANOVAs, t-tests, and chi-square tests. For this analysis, data were used of those employees who had participated in at least T1 and T3 and had completed all required questions on $\mathrm{T} 1$ and the question on whether or not one had started a training course between $\mathrm{T} 1$ and $\mathrm{T} 3(\mathrm{~N}=191)$.

To study the effect of training participation on learning self-efficacy (Hypothesis 1), a regression analysis was estimated with training participation between T1 and T3 as a predictor, and learning self-efficacy on T3 as a dependent variable. Learning self-efficacy at T1, age, gender and training participation in the five years before this study (before T1), were included as covariates in the model.

To study the effect of a positive learning experience on learning self-efficacy (Hypothesis 2), a regression analysis was estimated with learning experience as a predictor of learning self-efficacy at T3. Learning self-efficacy at T1, age, gender and prior training participation were included as covariates. We could however only test our second hypothesis on the data of 47 employees who participated in training between T1 and T3. We include prior training participation as a covariate because we want to make sure that training participation between T1 and T2 is responsible for changes in learning self-efficacy and not training participation in the five year period before our study period.

Table 4.1 presents the means, standard deviations and bivariate relations between the various variables. The table shows that men and women did not differ in T1 learning self-efficacy and in training participation between T1 and T3. Educational level is related to learning self-efficacy, but not to training participation. Employees who completed lower secondary education report a significantly higher learning self-efficacy than employees who only completed primary school or attended no school at all. Training participation prior to T1 has no relationship with learning selfefficacy at T1. Employees who participated in training prior to T1 participated more frequently in training during this study (T1 - T3), however. Finally, employees of 51 years and older report a significantly lower learning self-efficacy than those of younger ages. Employees in the age of 3150 more often participated in training between T1 and T3 than younger or older employees. 
Table 4.1 Employee characteristics and differences in self-efficacy and training participation (N)

\begin{tabular}{|c|c|c|c|c|c|}
\hline & \multirow[b]{2}{*}{$\mathbf{N}$} & \multicolumn{2}{|c|}{ Self-efficacy at T1 } & \multicolumn{2}{|c|}{$\begin{array}{c}\text { Training participation } \\
\text { between T1 and T3 (in \%) }\end{array}$} \\
\hline & & M & SD & No & Yes \\
\hline Total & 191 & 3.4 & 0.82 & 74.3 & 25.7 \\
\hline \multicolumn{6}{|l|}{ Gender } \\
\hline Male & 157 & 3.4 & 0.84 & 73.9 & 26.1 \\
\hline Female & 34 & 3.5 & 0.75 & 76.5 & 23.5 \\
\hline \multicolumn{6}{|l|}{ Education Level } \\
\hline Primary school or no education & 24 & $2.6^{* * *}$ & 1.08 & 79.2 & 20.8 \\
\hline Lower secondary education & 167 & $3.5^{\star * *}$ & 0.71 & 73.7 & 26.3 \\
\hline \multicolumn{6}{|l|}{ Prior training participation } \\
\hline No & 121 & 3.3 & 0.87 & $84.3^{* * *}$ & $15.7^{* * *}$ \\
\hline Yes & 70 & 3.5 & 0.74 & $57.1^{* \star *}$ & $42.9^{* * *}$ \\
\hline \multicolumn{6}{|l|}{ Age } \\
\hline 30 years or younger & 12 & 3.7 & 0.41 & 66,7 & 33.3 \\
\hline $31-50$ years & 96 & $3.6^{* * *}$ & 0.70 & $63.5^{* * *}$ & $36.5^{* * *}$ \\
\hline 51 years or older & 83 & $3.2^{* \star *}$ & 0.93 & $88.0^{* * *}$ & $12.0^{\star * *}$ \\
\hline
\end{tabular}

Note: Percentages are row percentages, tested with Pearson Chi-squared test (vertical comparisons). Averages are tested with t-test and ANOVA (vertical comparisons).

${ }^{*} p<.10,{ }^{* *} p<.05,{ }^{* * *} p<.01$ : significantly high (low) percentages and/or averages.

\subsection{Estimation results}

Tables 4.2 and 4.3 present the results of our regression analyses on learning self-efficacy. The table shows that training participation is not significantly related to the learning self-efficacy of less educated employees. This suggests there is no support for Hypothesis 1.

Table 4.2 Regression estimates for self-efficacy at T3

\begin{tabular}{|l|c|c|}
\hline & $\beta$ & SE \\
\hline Training participation between T1 and T3 & 0.02 & 0.12 \\
\hline Self-efficacy at T1 & $0.60^{\star * *}$ & 0.07 \\
\hline Gender & -0.09 & 0.15 \\
\hline Age & 0.01 & 0.01 \\
\hline Training participation prior to T1 & 0.17 & 0.11 \\
\hline Constant & $1.97^{* * *}$ & 0.48 \\
\hline N & & 149 \\
\hline Adj. $\mathrm{R}^{2}$ & & .38 \\
\hline
\end{tabular}

${ }^{*} p<0.10,{ }^{* *}: p<0.05,{ }^{* * *}: p<0.01$

For Hypothesis 2 - training participation that less educated employees consider a positive learning experience contributes to their learning self-efficacy - Table 4.3 provides empirical support. 
Less educated employees who report a positive learning experience have on average a higher learning self-efficacy $(\beta=.32, p<.05)$ and are thus more confident to successfully engage in future learning activities than less educated employees who do not have any positive learning experiences. Also, initial T1 learning self-efficacy was positively related to learning self-efficacy at Time $3(\beta=.42, p<.01)$.

Table 4.3 Effect for positive learning experience on learning self-efficacy

\begin{tabular}{|l|l|l|}
\hline & \multicolumn{2}{|c|}{ SE } \\
\hline Positive learning experience & $0.32^{* *}$ & 0.14 \\
\hline Self-efficacy at T1 & $0.42^{* *}$ & 0.18 \\
\hline Gender & 0.16 & 0.33 \\
\hline Age & 0.01 & 0.01 \\
\hline Training participation prior to T1 & 0.14 & 0.21 \\
\hline Constant & 4.40 & 3.10 \\
\hline N & & 39 \\
\hline Adj. $R^{2}$ & & .23 \\
\hline
\end{tabular}

${ }^{*} p<0.10,{ }^{* *}: p<0.05,{ }^{* * *}: p<0.01$

\subsection{Conclusions}

Less educated employees have been found to participate less in learning activities than higher educated employees. Yet, the dynamics in and around organizations emphasize the importance of continuous education for all employees (European Union, 2010; Kyndt \& Baert, 2013; Maurer et al., 2003). Engagement in learning activities secures employees' labour market position, and is considered a crucial adaptive behaviour that helps employees to sustain their employability by adjusting to a continuously changing work environment (Rainbird, 2000; Poell, van Dam, \& van den Berg, 2004; Van Dam, 2013). One explanation for less educated employees' training participation to lag behind is their reduced learning self-efficacy. Previous failure experiences at school may have undermined less educated employees' confidence that they are able to successfully engage in learning activities (Bandura, 1982; Illeris, 2006). Based on the Theory of Planned Behaviour (Ajzen, 1991) and Social Cognitive Theory (Bandura, 1977, 1982), we analysed whether participation in training might help to strengthen less educated employees' learning self-efficacy and whether it matters whether this training participation was actually a positive learning experience or not.

Our findings indicate that training participation does not enhance less educated employees' learning self-efficacy. Although employees who had participated in training during the study were found to have a higher self-efficacy at the end of the study, this difference can be explained by differences in learning self-efficacy at the beginning of the study and not by training participation 
itself. Our findings are in contrast with the findings of Maurer et al. (2003) who found a small positive relationship between prior training participation and learning self-efficacy. Since selfefficacy was measured only once in Maurer et al.'s study, this result may indicate that employees with a higher learning self-efficacy are more likely to participate in training instead of the other way around. Alternatively, our findings may be typical for less educated employees as Maurer et al. studied a sample including all educational levels. It is possible that mere training participation may not be enough for less educated employees to enhance their learning self-efficacy. For some training participants, the training may have resembled previous negative or unsuccessful learning experiences (Illeris, 2006). Our findings on whether positive learning experiences contribute to learning self-efficacy, show that a positive learning experience indeed increases less educated employees' learning self-efficacy. We conclude therefore that whereas 'just' participating in training does not have an effect on learning self-efficacy, participating in training that is considered a positive learning experience does have a positive effect.

This study adds to the existing literature showing that learning self-efficacy is positively related to workers' intentions to participate in future development activities, their attitude towards employee development programs in organizations, and their actual training participation (e.g., Hazelzet et al., 2011; Maurer \& Tarulli, 1994) This suggests that lifelong learning may be triggered by providing less educated employees with positive learning experiences aimed primarily at increasing their learning self-efficacy.

\subsubsection{Practical implications}

Our findings suggest that training developers and trainers who working for less educated employees should aim to develop training courses that provide positive learning experiences. If there is too much focus on the effectiveness of the training, or if training objectives are set too high, less educated employees' learning self-efficacy might suffer, and their intention to participate in any further training might vanish, harming their employability in the long run. There are several ways to design training courses that are most likely to be a positive experience for less educated employees. First, it is important to use a training setting that is similar to the workplace, with as little resemblance to a classroom as possible (Illeris, 2006). (Informal) workplace learning seems a suitable way for less educated employees to build their learning selfefficacy through gaining positive learning experiences. Another condition for overcoming initial reluctance pertains to a good fit between training content and the skills workers already have acquired. Moreover, employees should have a say in the form and content of the training, in order to meet their expectations and match the training with their wishes and abilities. Additionally, a trainer should provide a positive learning climate in which less educated employees dare to make errors, dare to ask questions and can learn in the way that suits them best (Schunk \& Pajares, 
2001). Next to focusing on the design of training courses, employers could also try to increase workers' learning self-efficacy by stimulating workers to communicate positive learning experiences (Geenen et al., 2013), as well as through discussing negative ones (Hazelzet et al., 2011). Moreover, coaching less educated employees in dealing with (the stress of) exams, may be another way to increase learning self-efficacy, since fear of exams is also a major obstacle for less educated to start training (Fouarge et al., 2013). To conclude, the measures mentioned here may all contribute to increased training participation of less educated employees and may trigger a process of lifelong learning. Engaging in this process of lifelong learning will strengthen less educated employees' labour market position. Moreover, it will help them to better adjust to continuous changes and as such improve their physical and psychological well-being (Van Dam, 2013) and to sustain their employability.

\subsubsection{Limitations and directions for future research}

This study has a few limitations. Although the study was longitudinal, with three measurement points in time, data collection for both learning experience and post-training self-efficacy took place after the training. Therefore, it is difficult to determine the direction of causality between learning experience and learning self-efficacy.

A second limitation concerns the use of self-reports, which could have contributed to the observed relationships. Yet, research indicates (Doty \& Glick, 1998) that common method variance is generally not robust enough to invalidate research findings. To avoid both the first and second limitation, separating the measurement of training participation and learning experience in time is considered to be a good strategy for future studies (Podsakoff et al., 2003).

A third limitation concerns the small number of respondents that remained for testing hypothesis $2(\mathrm{~N}=39)$ and the restricted number of organisations and branches participating in this study. We should be modest on the external validity of this study with respect to the entire population of less educated employees. Also, as $76 \%$ of the respondents in this study are male, we should be careful generalizing the findings to female employees.

Finally, for this study we use a rather strict definition of training by focusing on training spells lasting at least 6 months. To counter the third and final limitation we suggest that future studies aim to analyse a larger and more representative sample of less educated employees and to use different operationalisations of training participation, so that experiences with shorter training spells are also included. 


\section{Mobility}




\section{Chapter 5: Job-to-job mobility among less educated older employees $^{5}$}

\subsection{Introduction}

The working population in the Netherlands is growing older. The average age of employees in the Netherlands was 36.6 years in 1990; in 2000 it has increased to 38.1 years, and in 2014 it has further increased to 41.9 years (Statistics Netherlands, 2015). In the Netherlands, the austerity of possibilities for early retirement has already contributed greatly to the increase of the average retirement age and the labour participation rate of older employees. Yet, the labour participation of older employees still trails considerably (Otten et al., 2010). The greying of the working population makes it more and more important that employees remain productive until a higher age. Therefore, for many (older) employees (and their employers) the sustainability of their employment remains a clear challenge.

Mobility could be a useful route in sustaining employees' employability. Recent studies, however, show that less educated and older employees are less mobile than higher educated and younger employees (Gesthuizen \& Dagevos, 2005; Zwinkels et al., 2009). Hooftman et al. (2012) show that if less educated employees are mobile, it is usually involuntarily, for example due to a reorganization or a conflict. Why employees are less mobile has been thoroughly analysed (for a review see Feldman \& $\mathrm{Ng}, 2007$ ). Most studies in this review show that mainly dissatisfaction is an important precursor for job-to-job mobility. Sanders, van Wijk, Dorenbosch and Blonk (2011b) confirm these results for less educated employees in the Netherlands, by showing that a conflict with a line manager significantly increases internal mobility probabilities and that a conflict with colleagues significantly increases external mobility probabilities. These findings suggest that job mobility is usually not driven by finding a better use for their current skills. In their study, Sanders et al. (2011b) also find that gaining experience with external mobility improves voluntary external mobility. One seemingly fruitful way to stimulate less educated employees' mobility would therefore be through gaining positive experiences with external mobility. So far, however, there are, as far as we know, no empirical studies on the relations between positive external mobility experience and actual external mobility. This study aims to narrow this gap by answering the following question: What role does self-efficacy play in job-to-job mobility among less educated older employees?

5 This chapter is based on: Sanders, J., van Wijk, E., Boneschansker, O. \& J-F. Ybema (2012). Van baan naar baanmobiliteit bij laagopgeleide 45 plussers. (Job-to-job mobility among less educated older workers). Tijdschrift voor Arbeidsvraagstukken, 28(4), 474-490. (in Dutch) 
This study contributes to the HR literature on how to stimulate less educated older employees to become more mobile across jobs. We also contribute to the Theory of Planned Behaviour (TPB) literature, being one of the first to empirically test TPB on less educated older employees' job-tojob mobility behaviour.

This chapter proceeds as follows. Section 5.2 briefly discusses Ajzen's Theory of Planned Behaviour as a theoretical framework for studying job-to-job mobility behaviour. From this literature we derive five hypotheses. Section 5.3 describes the data, method and variables used to test these hypotheses. Section 5.4 presents the estimation results and Section 5.5 concludes.

\subsection{Theoretical background and hypotheses}

Many studies have used Ajzen's Theory of Planned Behaviour (TPB; Ajzen, 1985;1991) as an explanatory model for diverse types of behaviour (Van Breukelen et al., 2004; Raemdonck, 2006; Van Hooft et al., 2010; Hazelzet et al., 2011). The central assumption in Ajzen's TPB is that someone's intention to show a particular type of behaviour is a major determinant of that behaviour, as this intention is an indicator for the amount of effort someone is willing to make to perform this behaviour. Behavioural intentions are, according to TPB, influenced by at least three factors: attitude, subjective norm (expectations of third parties) and self-efficacy (confidence in one's own successful behaviour). The greater the existence of these three factors, the greater the intention of behaviour, which increases the chance that the behaviour actually takes place. In this study, we focus on the third factor, that of self-efficacy or perceived behavioural control. Selfefficacy can be strengthened by successful experiences, through learning from others, through verbal conviction or through a transformed psychological or emotional state. Research by Bandura $(1989,2001)$ shows that in particular successful experiences are important for increasing someone's self-efficacy.

Our expectation that a fruitful way to stimulate less educated older employees' voluntary external mobility would be through gaining positive experiences with external mobility builds on Ajzen's TPB and Bandura's SCT in that gaining positive external mobility experience is expected to increase less educated employees' intentions to become externally mobile through an increase in 'mobility self-efficacy'. Following Fishbein and Ajzen's Theory of Reasoned Action (Fishbein \& Ajzen, 1975) this increase in mobility intentions is expected to automatically lead to an increase in actual voluntary external mobility. Studies into relations between positive learning experience, pre-training self-efficacy, training intention and training participation of the less educated show that positive learning experiences strengthen pre-training self-efficacy and training intentions and increase less educated employees' training participation (see Chapters 3 and 4 of this thesis) 
whereas Sanders et al. (2011b) show that external mobility in the past is a predictor for voluntary external mobility. These findings suggest that previous successful external mobility might stimulate future voluntary external mobility. In this study, following Ajzen's TPB and Bandura's notion that positive experiences will stimulate specific behaviour (Bandura, 1982; 1989;2001), we examine the relationships between on the one hand the confidence in being able to find a new employer (self-efficacy), and on the other hand the intention to leave the current employer and actual job change. For this purpose, we will test three hypotheses:

Hypothesis 1: Less educated older employees' confidence in being able to find a new employer (self-efficacy) is lower than higher educated older employees' confidence.

Hypothesis 2: Older employees' confidence in being able to find a new employer (self-efficacy) has a positive relation to their intention to leave their current employer.

Hypothesis 3: Older employees' confidence in being able to find a new employer (self-efficacy) has a positive relation to actual job change.

Various studies on (perceived) employability (e.g. Nauta, Van Vianen, Van der Heijden, Van Dam \& Willemsen, 2009; Wittekind, Raeder \& Grote, 2010) suggest the relationships described in Hypotheses 1, 2 and 3 to be different between less and higher educated older employees. We may expect that these differences are caused by differences in perceived employability levels and career opportunities, differences in job satisfaction levels and the positive relationship between job satisfaction and job-to-job mobility. De Graaf-Zijl (2011) shows that less educated employees are generally less satisfied with their job than higher educated employees. Employees who are less satisfied with their job have also been shown to feel more urgency to change jobs (Griffeth, Hom \& Gaertner, 2000; Van Dam, 2005; Nauta et al., 2009). These findings suggest a negative relationship between a workers' level of education and job-to-job mobility. Less educated employees theoretically would then be more inclined to change jobs. However, Gesthuizen \& Dagevos (2005); Zwinkels et al. (2009) and Hooftman et al. (2012) and others have shown that this relationship between education level and job-to-job mobility is a positive relationship, rather than a negative one. Therefore, higher levels of job dissatisfaction among less educated employees do not seem to push them out of their job. We suggest that this may be due to the fact that less educated older employees have less employment opportunities to do so than higher educated older employees leading also to lower perceived employability levels (Wittekind et al., 2010) and less job-to-job mobility (Trevor, 2001). We expect, however, that less educated older employees who are confident about being able to find a new employer, will be more willing to 
change jobs and will do so more often than higher educated older employees because of differences in job satisfaction levels. From this we derive Hypotheses 4 and 5 :

Hypothesis 4: Among less educated older employees the positive relation between the confidence in being able to find a new employer (self-efficacy) and the intention to leave is stronger than among higher educated older employees.

Hypothesis 5: Among less educated older employees the positive relation between the confidence in being able to find a new employer (self-efficacy) and actual job change is stronger than among higher educated older employees.

Figure 5.1 presents an overview of the five hypotheses we will test in this paper, and the expected signs of the relationships.

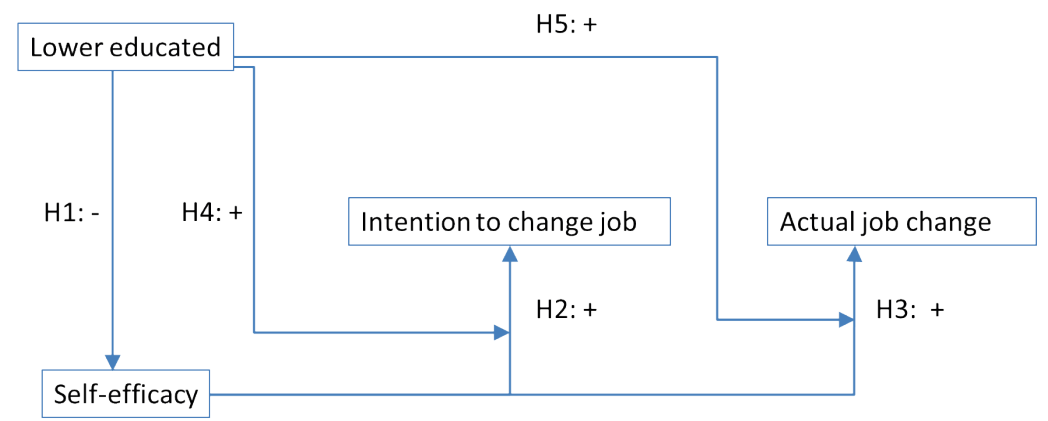

Figure 5.1 Overview hypotheses on the intention to change jobs and actual job change

\subsection{Method}

\subsubsection{Data, participants and procedure}

This study is based on the Study on Transitions in Employment, Ability and Motivation (STREAM). STREAM is a large-scale longitudinal research into transitions in labour among persons aged 45-64 ('older employees'). The main objective of STREAM is the identification of circumstances under which over-45s participate (longer) in paid employment while maintaining good health and good productivity. Data from STREAM offer the opportunity to gain a better understanding of the situation of less educated older employees and of how this differs with that of intermediate and higher educated employees. For more information regarding the methodology, survey and descriptive results from the STREAM research, see Ybema et al. (2011a). 
In this study, we focus on the respondents who are employed. The multiple linear regression analyses in this study are estimated on data from the first survey wave (2010) among 12,055 employees aged 45 or older. The longitudinal analyses on actual job change between T1 (2010) and T2 (2011) includel 9,153 employees aged 45 or older.

\subsubsection{Measures}

The intention to change jobs is measured at T1 by asking employees whether they plan to change jobs in the next twelve months. The answer category for this question ranges from 'absolutely not' to 'absolutely' on a 5-point scale.

(Job change) self-efficacy is measured at T1 by asking employees whether they think themselves capable of finding a new employer in the next twelve months. Here too, use is made of a 5-point Likert scale that runs from 'absolutely not' to 'absolutely'.

Actual job change is measured at T2 by asking employees whether they have changed their employer in the previous twelve months. Employees could respond with either yes or no.

The level of education is determined by asking respondents what their highest diploma-certified qualification is. Respondents could choose from seven levels of education ranging from 1: no education/primary education to 7: higher education/post-graduate. For this study, a distinction is made between two groups, namely less educated and higher educated. Less educated are employees with a maximum of lower secondary education (ISCED <3). Respondents are higher educated employees when they have completed at least intermediate vocational education (ISCED 3 or up).

Finally, we control for age and gender at baseline (T1). The age of the respondent is derived from the date of birth. Age is measured and included in our models as a continuous variable.

\subsubsection{Analysis}

We will first show the bivariate correlations between educational level, gender, age, (job change) self-efficacy, the intention to change jobs and actual job change. Hypotheses 1,2 and 4 are then tested by estimating multiple linear regressions. First, we examine the direct relationships between self-efficacy and employees' intentions to change jobs. Subsequently, we look whether this relationship is moderated by the educational level. Hypotheses 3 and 5 are tested by estimating multiple logistic regressions on actual job change between T1 and T2, in which all predictors are measured at T1. In all our analyses the scores on confidence are centred to avoid 
high correlations with the main effects and the interaction effects (Aiken \& West, 1991). Given the large sample, we consider an effect to be statistically significant only when the p-value is less than .01 .

\subsection{Estimation results}

In Table 5.1 we first offer an overview of the Pearson correlations for the dependent, independent and covariates in this study. The table shows that less educated older employees' self-efficacy is lower than that of higher educated employees. Educational level shows a weak negative correlation with self-efficacy $(r=-0.152 ; p<.01)$. Table 5.1 also shows that self-efficacy positively correlates with the intention to change jobs $(r=0.271 ; p<.01)$ and with actual job change between T1 and T2 $(r=0.100 ; p<.01)$. From Table 5.1 it is also notable that less educated older employees have less intention to change jobs than higher educated older employees $(r=-0.095$; $p<.01)$, and that they are not less likely to actually change jobs $(r=-.006$; ns). Finally, Table 5.1 shows that self-efficacy decreases with age $(r=-.394 ; p<.01)$.

Table 5.1 Correlations between the variables in the model $(N=9,058)$

\begin{tabular}{|c|c|c|c|c|c|}
\hline & 1 & 2 & 3 & 4 & 5 \\
\hline 1. Educational level ( $1=$ low; $0=$ middle or high) & . & & & & \\
\hline 2. Gender (1=male; $2=$ female $)$ & $.048^{* * *}$ & . & & & \\
\hline 3. Age (in years) & $.071^{* * *}$ & $-.033^{* * *}$ & . & & \\
\hline 4. Self-efficacy & $-.152^{* * *}$ & -.025 & $-.394^{* * *}$ & & \\
\hline 5. Intention of changing jobs & $-.095^{\star * *}$ & .005 & $-.269^{\star * \star}$ & $.271^{* * *}$ & . \\
\hline 6. Actual job change between T1 and T2 ( $1=$ yes; $0=$ no) & -.006 & .016 & $-.080^{* * *}$ & $.100^{* * *}$ & $.246^{* * *}$ \\
\hline
\end{tabular}

${ }^{* * *} p<.01$

Next, to test Hypothesis 1 we estimated a linear regression model on job change self-efficacy. The estimation results in Table 5.2 show that less educated older employees' job change selfefficacy is indeed lower than that of higher educated employees. This confirms the expectations of Hypothesis 1. Moreover Table 5.2 shows that female workers' job change self-efficacy is lower than that of male workers and that job change self-efficacy decreases with age.

Table 5.2 Linear regression with job change self-efficacy (Hypothesis 1)

\begin{tabular}{|c|c|c|}
\hline & $\beta$ & SE \\
\hline Educational level ( $1=$ low; $0=$ middle or high) & $-0.33^{* * *}$ & 0.02 \\
\hline Gender (1=male; $2=$ female) & $-0.09^{* \star *}$ & 0.02 \\
\hline Age (in years) & $-0.09^{* * *}$ & 0.00 \\
\hline Constant & $5.06^{\star * *}$ & 0.11 \\
\hline $\mathrm{N}$ & \multicolumn{2}{|c|}{12,013} \\
\hline Adj. $R^{2}$ & \multicolumn{2}{|c|}{.18} \\
\hline
\end{tabular}


Table 5.3 shows the results of a multiple linear regression analyses on employees' intention to change jobs. The results in column (1) show that employees with more (job change) self-efficacy have a stronger intention to change jobs $(\beta=0.16 ; p<.01)$, confirming Hypothesis 2 . Column (2) in Table 5.3 shows that there is no difference, however, between lower and higher educated older employees in the relationship between employees' self-efficacy and the intention to change jobs. The inclusion of the interaction term between educational level and self-efficacy does not contribute to the explanation of employees' intention to change jobs. Hypothesis 4, which poses that the positive relationship between self-efficacy and the intention to change jobs is stronger among less educated older employees than among higher educated older employees, therefore needs to be rejected.

Table 5.3 Linear regression estimates of the intention of changing jobs (Hypotheses 2 and 4)

\begin{tabular}{|c|c|c|c|c|}
\hline & \multicolumn{2}{|c|}{ (1) } & \multicolumn{2}{|c|}{ (2) } \\
\hline & $\beta$ & SE & $\beta$ & SE \\
\hline Educational level ( $1=$ low; $0=$ middle or high) & $-0.10^{* * *}$ & 0.02 & $-0.10^{\star * *}$ & 0.02 \\
\hline Gender ( $1=$ male; 2 =female) & $-0.00^{* * *}$ & 0.02 & $-0.00^{* * *}$ & 0.02 \\
\hline Age (in years) & $-0.03^{* * *}$ & 0.00 & $-0.03^{* * *}$ & 0.00 \\
\hline Self-efficacy & $0.16^{* * *}$ & 0.01 & $0.16^{* * *}$ & 0.01 \\
\hline Interaction self-efficacy ${ }^{*}$ less educated & & & 0.00 & 0.02 \\
\hline Constant & 3.31 & 0.09 & 3.31 & 0.09 \\
\hline $\mathrm{N}$ & \multicolumn{2}{|c|}{11,934} & \multicolumn{2}{|c|}{11,934} \\
\hline Adj. $R^{2}$ & \multicolumn{2}{|c|}{.11} & \multicolumn{2}{|c|}{.11} \\
\hline
\end{tabular}

*** $p<0.01$

To test Hypotheses 3 and 5 we carry out multiple logistical regression analyses on actual job change between T1 and T2. These analyses only include those who have participated in both panel waves and did not have any missing values for the relevant variables, leaving us with data on 9,153 older employees. The results are presented in Table 5.4.

Table 5.4 Logistic regressions of actual job change between T1 and T2 (Hypotheses 3 and 5) (all predictors measured at T1)

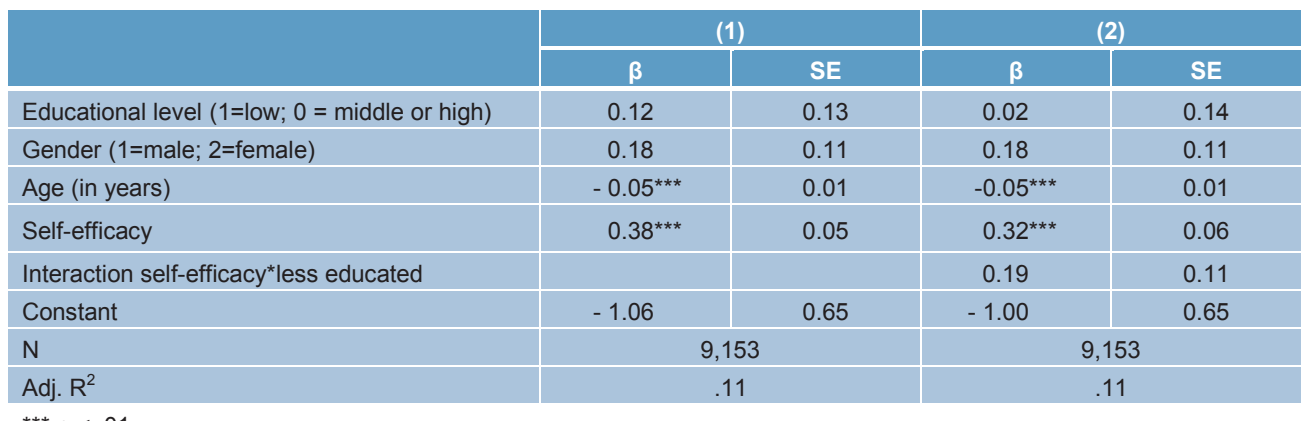


Column (1) in Table 5.4 shows the main effect of (job change) self-efficacy on actual job change. The estimation results show that the probability of actually changing jobs is higher as employees have more self-efficacy $(\beta=0.38 ; p<.01)$. Hypothesis 3 , proposing that older employees' confidence in being able to find a new employer has a positive relationship with actual job change, is therefore confirmed. Column (2) shows the results of the regression including the interaction term between education level and self-efficacy. The estimation results show that the relation between the confidence in being able to find a new employer and job change is not significantly stronger among less educated older employees than among higher educated older employees. Hypothesis 5 is therefore rejected. ${ }^{6}$ Figure 5.2 summarizes the results of the above analyses with respect to the five hypotheses.

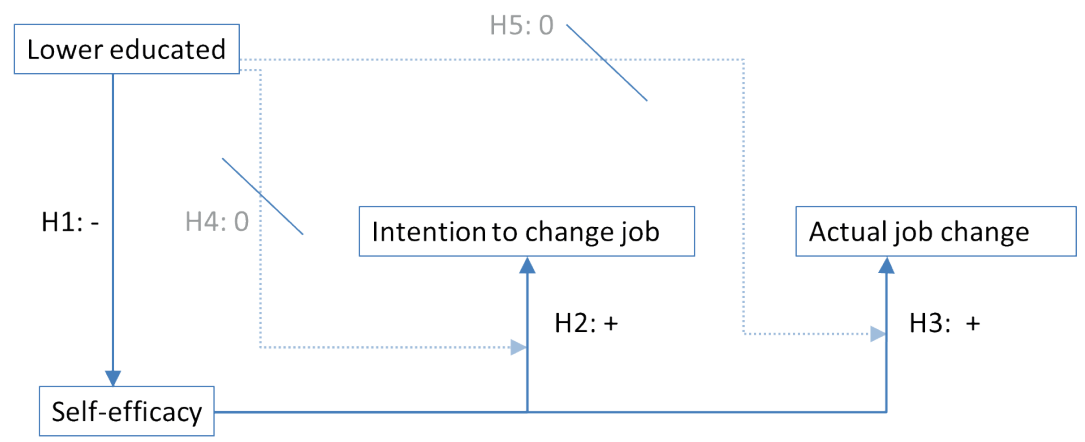

Figure 5.2 Path model for the prediction of the intention to change jobs and actual job change

\subsection{Conclusions}

In this study, we aim to find out what role job change self-efficacy plays in actual job-to-job mobility among less educated older employees. We answer this central question using the theoretical framework of Ajzen's Theory of Planned Behaviour (TPB: Ajzen, 1985; 1991; 2001) and Bandura's Social Cognitive Theory (SCT; Bandura, 1989; 2001). Building on these theories we expect that increasing less educated older employees' job change self-efficacy will increase their intentions to change jobs, leading to a higher probability of actual job change. In this study, we test five hypotheses. In accordance with our first hypothesis, we find that less educated older employees have less 'job change self-efficacy' than higher educated older employees. Next, in accordance with TPB and with our second and third hypothesis, we find that job change selfefficacy is positively related to both the intention to change jobs and actual job change. However, we do not find empirical support for our fourth and fifth hypotheses. The relationships between

6 Additional analyses including the interaction term between self-efficacy and age show that age does not mediate the relationship between self-efficacy and the intention to change jobs or actual job change. 
job change self-efficacy and the intention to change jobs as well as actual job change are not different for less educated than for higher educated older employees.

Our findings show that the lower levels of job change self-efficacy could explain why less educated older employees' mobility behaviour lags behind that of higher educated older employees. Active encouragement of job change self-efficacy to enable a successful job change can therefore be an important first step in increasing voluntary job-to-job transitions of less educated older employees. This implies that labour market and HR policies that are specifically designed for groups of precarious workers, such as the less educated older employees, should focus on strengthening employees' job change self-efficacy. An interesting follow-up question is then how this job change self-efficacy can be encouraged, specifically among less educated older employees. Bandura (2001) shows that in particular individual successful experiences (enactive self-mastery) are highly relevant for gaining self-efficacy although learning from other's success stories and good practices (role modelling), social or verbal persuasion or a transformed psychological or emotional state also make a contribution. Therefore, it seems fruitful to further develop HR practices that enable less educated employees to gain positive experience with different types of job-to-job mobility throughout their career and to expressly address and share these experiences. Experiencing and sharing successful 'transitions' can contribute to less educated employees job change self-efficacy in their late career, stimulating them to 'keep moving'. The extent to which less educated employees require a different approach than higher educated employees, for instance due to a difference in individual successful mobility experiences, the availability and sharing of success stories of others or a different emotional state, are to be determined in further research. One suggestion for less educated employees, however, would be to take smaller steps in gathering mobility experiences. For instance by not changing jobs, but by starting with some kind of partial mobility, maybe even 'just' changing tasks, routines or departments, so that employees and employers can gradually build on these experiences. Whether small or big change experiences strengthen less educated (older) employees' capabilities to keep moving needs to be studied more closely.

\subsubsection{Limitations}

Although this study has strengths in that it is a large-scale research of a heterogeneous group of older employees, one limitation of the study is the use of self-reports for measuring the study variables, which could be responsible, at least in part, for the observed relationships. Yet, research indicates (Doty \& Glick, 1998) that common method variance is generally not robust enough to invalidate research findings. Separating the measurements of the theoretical variables may offer a good strategy to avoid this limitation in future research, however (Podsakoff et al., 2003). 


\section{Work Redesign}




\section{Chapter 6: Sustaining less educated older employees' employability: exploring possibilities for work redesign ${ }^{7}$}

\subsection{Introduction}

In this study we explore the possibilities for work redesign focusing on the question: what possibilities for work redesign are most promising, particularly for sustaining less educated older employees' employability?

To find an answer to this central question, we focus on answering three related research questions:

1. How do work characteristics of less educated older employees differ from older employees with higher levels of education?

2. Which work characteristics of less educated older employees are related to their work ability and work motivation?

3. What characteristics of less educated older employees' work are particularly promising for work redesign?

By answering these three research questions, we add to the literature on job crafting and its contribution to less educated older employees' sustainable employability. Also, we add to the literature on testing the Job Characteristics Model (JCM), since this study is one of the first to analyse the relationships between the prevalence of specific categories of work characteristics and less educated older employees' work ability as well as work motivation.

This chapter proceeds as follows. Section 6.2 briefly discusses the literature on JCM, work characteristics and their relationships with two central aspects of sustainable employability, namely work ability and work motivation. From the literature we derive eight hypotheses. Section 6.3 describes our data, method and variables used and Section 6.4 presents the estimation results. Section 6.5 concludes.

7 This chapter is based on: Sanders, J., Dorenbosch, L., Gründemann, R., \& Blonk, R. (2011). Sustaining the work ability and work motivation of lower educated older workers: directions for work redesign. Management Revue, 22(2), 132-150. 


\subsection{Theoretical background and hypotheses}

As theoretical starting point for this study we use an elaborated version of the classic Job Characteristics Model (JCM) (Hackman \& Lawler, 1971; Hackman \& Oldham, 1980). JCM gave rise to a great number of studies in the field of work psychology concerning the evaluation and design of high-quality jobs. During the 1980s, the model's five structural characteristics concerning job quality - task variety, autonomy, feedback, significance and identity - were extensively tested on their dimensionality and relationship with favourable employee and organizational outcomes. Over the years the traditional job characteristics model has been expanded. For example, Karasek (1979) called for the inclusion of job demands, as the relationship between job design and employee well-being involves interplay between job demands and the decision latitude that the job provides. Recent elaborations (e.g., Grant \& Parker, 2009) have been fuelled by the changing nature of work, such as increasing levels of social interaction, increased information processing, teamwork and other requirements arising from the need to interact with beneficiaries such as customers, patients and suppliers.

The expanded version of JCM developed by Humphrey et al. (2007) includes social aspects of work, such as interdependence, feedback from others, social support and interaction outside the organization, as well as contextual factors traditionally examined in the literature on human physiology, such as physical demands, working conditions and ergonomics. Their meta-analysis of 259 studies revealed that these additional social and contextual work characteristics have comparable relationships with the work outcomes associated with the traditional job characteristics of the JCM. The authors stress the importance of focusing on work design rather than job design, as a focus on the former emphasizes the important link between a job and the broader work environment (Morgeson \& Humphrey, 2006).

Following Morgeson and Humphrey (2006) and their Work Design Questionnaire (WDQ), we now distinguish four categories of work characteristics:

1. Contextual work characteristics reflect the context in which work is performed, including physical and environmental aspects (e.g., physical demands, dangerous work);

2. Cognitive-informational or knowledge work characteristics reflect the skill, ability and knowledge demands that are placed on an employee performing the work (e.g., job complexity, job demands, time pressure);

3. Task-motivational work characteristics reflect how and in what order work and tasks are accomplished (e.g., autonomy, task variety); 
4. Social work characteristics reflect the level of interaction with colleagues, managers and/or customers or patients work involves (e.g., social support, emotional demands and customer contact).

\subsubsection{Contextual work characteristics}

According to sociological research on the role of education in the stratification of labour market opportunities (e.g. Warren et al., 2004), education allocates employees over the various job types. Entry-level blue-collar jobs in manufacturing, construction, agriculture, catering and cleaning traditionally attract a high proportion of less educated employees, while white-collar clerical and professional work require higher levels of education. With the exception of the socalled 'McJobs', referring to low-paid, low-prestige jobs in the service sector which require few skills (Lindsay, 2005), less educated employees often have jobs that involve manual work in standardized work processes, with less educated employees more often working in jobs that are more physically demanding but less cognitively demanding. The European Working Conditions Survey (EWCS) (Parent-Thirion et al., 2005), covering about 30,000 employees in 27 EU Member States, showed that employees in blue-collar jobs report higher exposure to biological, chemical and ergonomic health risks as opposed to employees in white-collar jobs. Based on these findings, the first hypothesis of this study is:

Hypothesis 1: Less educated older employees more often face demanding contextual work characteristics than higher educated older employees.

\subsubsection{Cognitive-informational and task-motivational work characteristics}

Based on Morgeson and Humphrey's Work Design Questionnaire (WDQ, 2006), we distinguish cognitive-informational and task-motivational work characteristics as the characteristics that are expected to enrich work and make it more satisfying and motivating. Cognitive-informational and task-motivational characteristics are the set of 'traditional' motivational job characteristics from Hackman and Oldham's Job Diagnostic Survey (1980) (e.g., autonomy, task variety, complexity and time pressure). The EWCS survey showed that employees' level of education has a strong relationship with the level of cognitive demands at work.

In this EU survey, high cognitive demands involve solving unforeseen problems independently, engaging in complex tasks and learning new skills, while low cognitive demands refer to monotonous and repetitive tasks. Employees with a lower level of education have jobs with lower scores on all cognitive work aspects, which indicates fewer cognitive-informational work characteristics. Moreover, Morgeson and Humphrey (2006), who do not distinguish between levels of education but between occupations, found that employees in non-professional 
occupations which generally require lower levels of education, score lower on cognitiveinformational work characteristics than employees in professional jobs which generally require intermediate or higher education (e.g., sales occupations or health care). We expect to replicate these results with respect to differences between less and higher educated workers. Therefore, our second and third hypotheses are:

Hypothesis 2: Less educated older employees have lower cognitive-informational work characteristics than higher educated employees.

Hypothesis 3: Less educated older employees have lower task-motivational work characteristics than higher educated employees.

\subsubsection{Social work characteristics}

With regard to relational work characteristics that relate to the degree of social interaction a job requires, we also expect differences between lower and higher educated employees. It could be argued that the higher levels of standardization and the often highly visible output of the jobs of less educated employees require less formal communication among colleagues about job execution and job results. As such, explicit social support, for instance in terms of positive feedback or compliments, from colleagues and supervisors is often not a formalized feature of the job. The EWCS survey showed that blue-collar employees report less social support from colleagues and supervisors (Parent-Thirion et al., 2005). Furthermore, the EWCS data revealed that in general among blue-collar employees the pace of work is less determined by working with people and colleagues and more by numerical production targets or by the supervisor. This suggests a work setting in which the job of less educated employees involves fewer social interaction. Therefore, our fourth hypothesis is:

Hypothesis 4: Less educated employees have lower social relational work characteristics than higher educated employees.

\subsubsection{Work characteristics, work ability and work motivation}

The ability and motivation to continue working are expected to be influenced by various work characteristics. Since we are primarily interested in finding ways to sustain less educated older workers employability, we now focus on work characteristics that specifically predict less educated older workers' work ability and/or work motivation. The meta-analysis by Humphrey et al. (2007) demonstrated that task-motivational, knowledge, social and contextual work characteristics have an impact on various behavioural, attitudinal and well-being related work outcomes. For example, contextual physical demands were found to relate to both attitudinal 
(less job satisfaction) and well-being outcomes (more stress and exhaustion). At an older age particularly, it becomes increasingly likely that the health of employees will be damaged by high physical demands because physical skills 'wear' and make employees more vulnerable to the effects of heavy labour (Burdorf \& Mackenbach, 2006). In line with earlier findings, this leads to the following hypothesis:

Hypothesis 5: Demanding contextual work characteristics relate negatively to the work ability and work motivation of less educated older employees.

Cognitive-informational work characteristics, reflecting the knowledge demands in the job, have been shown to affect work motivation as well as work ability in a positive way. Morgeson and Humphrey (2006) revealed that knowledge characteristics, such as job complexity, are positively related with motivational outcomes such as job satisfaction. In an earlier study, Edwards et al. (2000) also found that work involving complex tasks and requiring high-level skills is considered mentally more demanding and more challenging and thus more motivating than work that involves 'simple' tasks. This implies a positive relationship between cognitive-informational work characteristics and work motivation. We also expect a positive relationship between cognitiveinformational work characteristics and work ability, since work that is mentally more demanding will also be more instructive. We expect employees with more and different skills to report a higher work ability. These findings also relate to the literature in which task or emotional demands are considered as work characteristics that can be viewed as 'challenge' or 'positive' stressors (as opposed to 'hindrance' or 'negative' stressors). Challenge stressors have been reported to spark positive work attitudes (e.g., Podsakoff et al., 2007) improving both work motivation and ability. Thus, our sixth hypothesis is:

Hypothesis 6: Cognitive-informational work characteristics relate positively to work ability and work motivation of less educated older employees.

Finally, task-motivational and social work characteristics are considered important work resources that strengthen employee well-being and work motivation (e.g., Schaufeli \& Bakker, 2004). They are also considered essential resources to buffer aspects of work that impair health and thus to strengthen work ability (Karasek \& Theorell, 1990). Task-motivational and social work characteristics support individual employees' experience of for instance autonomy and relatedness which, in accordance with self-determination theory (Deci \& Ryan, 2000), foster intrinsic work motivation and via engagement and wellness also work ability. There is also some evidence that low autonomy jobs (Quinn 1978, Holte, Korkstadt, \& Magnus, 2000) are associated with early retirement, implying lower levels of work ability and/or work motivation. Finally, the 
meta-analysis by Humphrey et al. (2007) revealed that task-motivational as well as social work characteristics explain a large part of the variance in work motivational outcomes. Thus, the seventh and eighth hypotheses of our study are:

Hypothesis 7: Task-motivational work characteristics relate positively to the work ability and work motivation of less educated older employees.

Hypothesis 8: Social work characteristics relate positively to the work ability and work motivation of less educated older employees.

\subsection{Method}

\subsubsection{Data}

This study uses data from the Netherlands Working Conditions Cohort Study (NWCCS) (see also Koppes et al., 2011), a longitudinal dataset on Dutch employees. The baseline and follow-up questionnaires contained approximately 200 questions on professional and job characteristics, physical and psychological working conditions, as well as company and other policies. Data were gathered through written questionnaires or an identical online version. In 2007, the baseline questionnaire (T1) was sent to a random representative sample of 80,000 Dutch employees. 22,759 employees responded to this baseline questionnaire. 19,260 employees consented to follow-up assessments and in 2008 , these employees received the first follow-up questionnaire (T2). This follow-up questionnaire was completed by 10,393 employees. The respondents to the T1 and T2 questionnaires were matched using their unique social security numbers. For the empirical analyses, we selected employees aged 45 to 65 with a permanent or temporary contract in the baseline year 2007. A sample of 5,002 older employees remains for testing Hypotheses 1 to 4 . As the Hypotheses 5 to 8 focus on less educated older employees only, we test these hypotheses using a subsample of 1,263 less educated older employees. The average age of employees in this subsample is $53.53 \%$ are male, $94 \%$ have a permanent contract and $54 \%$ work fulltime (at least 35 hours per week).

\subsubsection{Variables}

Table 6.1 presents an overview of the single-item measures used in this study, including sample items, scale reliabilities (when relevant) and response formats. Several indicators covering work ability and work motivation were used as the dependent variables in this study. 
Work ability contains single-item measures for three indicators: a self-reported general health status (Houtman et al., 1995) and the physical and mental ability to work (Van den Bossche \& Houtman, 2007).

For work motivation the study includes three indicators: an open question for the preferred retirement age, a single-item measure for job satisfaction and a 4-item scale for work engagement based on the 'dedication' subscale of the Utrecht Work Engagement Survey (UWES) (Schaufeli et al., 2002). These measures combined indicate whether an employee enjoys working in general and working in a specific current job and whether the employee is motivated to keep working until his or her retirement age.

Contextual characteristics refer to dangerous work, physical strain, repetitive tasks and working in an uncomfortable position. Single-item measures of self-reports of these working conditions were retrieved from a population survey (EBB) of Statistics Netherlands (CBS). The four variables mentioned aim to indicate the contextual dimensions Morgeson and Humphrey (2006) distinguish in their WDQ. The ergonomics dimension is measured by asking whether employees work in uncomfortable positions and whether they perform repetitive tasks. The physical demands dimension is measured by asking about physical strain, the working conditions dimension is measured by asking whether employees experience dangerous work. The dimension equipment use could not be measured in our data.

Cognitive-informational work characteristics are measured with the scales of job complexity (Houtman et al., 1995), time pressure and task demands, both taken from the Job Content Questionnaire (JCQ) (Karasek, 1985), which indicate the extent to which the work requires intensive thinking and fast information processing. Job complexity indicates whether tasks in a job are difficult. Research by Edwards, Scully and Brtek (2000) indicated that performing complex tasks requires the use of different skills. Complex jobs therefore are more challenging and likely to be more motivating. Time pressure and task demands are other variables that indicate whether employees work with 'high cognitive demands' making jobs more challenging, richer and therefore more motivating.

Task-motivational work characteristics in our model refer to autonomy and task variety, traditional core motivational factors in the Job Characteristics Model. Scales for autonomy and task variety are retrieved from Karasek's JCQ (1985). Autonomy indicates the level of freedom in work scheduling, work methods and decision making. A vast body of research has shown that autonomy is positively related to work motivation and work ability (e.g. Hackman and Oldham, 1976). Task variety refers to the degree an employee performs different tasks in his or her job. 
Research has repeatedly shown that jobs involving different tasks are interesting and more enjoyable (e.g. Sims, Szilagyi, \& Keller, 1976).

Social characteristics or social support are measured with scales for social support by colleagues, social support by supervisor, both taken from the JCQ (Karasek, 1985), emotional workload (Houtman et al., 1995) and the frequency of contact or 'social interaction' within and outside the team/organization (based on items in the Community Innovation Survey, Eurostat, 2004). Social support by colleagues and supervisors indicates whether workers have access to advice and assistance in the workplace. These types of support have been shown to be highly relevant for employee well-being (Ryan \& Deci, 2001). Emotional workload indicates whether employees are at risk of experiencing job stress. High levels of emotional workload need to be 'buffered', for instance by higher levels of social support (Karasek, 1985). Finally, social work characteristics are measured by the frequency with which employees are in contact with customers. This measure indicates what Morgeson and Humphrey (2006) have called 'interaction outside the organisation' in the WDQ.

Table 6.1 Overview of variables used in this study

\begin{tabular}{|c|c|c|c|}
\hline Variables & Sample items & $\begin{array}{l}\text { Cronbach's } \\
\text { alpha }\end{array}$ & $\begin{array}{l}\text { Answer } \\
\text { categories }\end{array}$ \\
\hline \multicolumn{4}{|l|}{ Work ability } \\
\hline Health status & How would you describe your health in general? & - & $\begin{array}{l}1=\text { Bad } \\
5=\text { Excellent }\end{array}$ \\
\hline $\begin{array}{l}\text { Physical ability to } \\
\text { work }\end{array}$ & $\begin{array}{l}\text { How would you describe your ability to work, considering the } \\
\text { physical demands of your job? }\end{array}$ & - & $\begin{array}{l}1=\text { Very bad } \\
5=\text { Very good }\end{array}$ \\
\hline $\begin{array}{l}\text { Mental ability to } \\
\text { work }\end{array}$ & $\begin{array}{l}\text { How would you describe your ability to work, considering the } \\
\text { psychological demands of your job? }\end{array}$ & - & $\begin{array}{l}1=\text { Very bad } \\
5=\text { Very good }\end{array}$ \\
\hline \multicolumn{4}{|l|}{ Work Motivation } \\
\hline $\begin{array}{l}\text { Preferred } \\
\text { retirement age }\end{array}$ & To what age do you want to continue working? & - & $\begin{array}{l}\text {....[age] } \\
\text { Continuous }\end{array}$ \\
\hline Job satisfaction & All in all, to what extent are you satisfied with your job? & - & $\begin{array}{l}1 \text { = Very } \\
\text { dissatisfied } \\
5=\text { Very satisfied }\end{array}$ \\
\hline Engagement & $\begin{array}{l}\text { 4-item scale } \\
\text { Sample item: I am proud of the work that I do }\end{array}$ & .89 & $\begin{array}{l}1=\text { Never } \\
4=\text { Always }\end{array}$ \\
\hline \multicolumn{4}{|c|}{ Contextual work characteristics } \\
\hline Dangerous work & Do you have to perform dangerous tasks? & - & $\begin{array}{l}1=\text { No } \\
2=\text { Yes, } \\
\text { sometimes } \\
3=\text { Yes, } \\
\text { regularly }\end{array}$ \\
\hline $\begin{array}{l}\text { Physical strain } \\
\text { (using force) }\end{array}$ & $\begin{array}{l}\text { Do you perform tasks that require you to use a lot of force; } \\
\text { for example, lifting, pushing, pulling or heaving, or do you } \\
\text { use tools that require you to use force? }\end{array}$ & - & $\begin{array}{l}1=\text { No } \\
2=\text { Yes, } \\
\text { sometimes } \\
3=\text { Yes, }\end{array}$ \\
\hline
\end{tabular}




\begin{tabular}{|c|c|c|c|}
\hline Variables & Sample items & $\begin{array}{l}\text { Cronbach's } \\
\text { alpha }\end{array}$ & $\begin{array}{c}\text { Answer } \\
\text { categories }\end{array}$ \\
\hline & & & regularly \\
\hline Repetitive work & Does your job require repetitive movements? & - & $\begin{array}{l}1=\text { No } \\
2=\text { Yes, } \\
\text { sometimes } \\
3=\text { Yes, } \\
\text { regularly }\end{array}$ \\
\hline $\begin{array}{l}\text { Uncomfortable } \\
\text { position }\end{array}$ & Do you work in uncomfortable working positions? & - & $\begin{array}{l}1=\text { No } \\
2=\text { Yes, } \\
\text { sometimes } \\
3=\text { Yes, } \\
\text { regularly }\end{array}$ \\
\hline \multicolumn{4}{|c|}{ Cognitive-informational work characteristics } \\
\hline Job complexity & $\begin{array}{l}\text { 3-item scale } \\
\text { Sample item: Does your work demand intensive thinking? }\end{array}$ & .79 & $\begin{array}{l}1=\text { Never } \\
4=\text { Always }\end{array}$ \\
\hline Time pressure & $\begin{array}{l}\text { 2-item scale } \\
\text { Sample item: Do you have to work at a high pace? }\end{array}$ & .81 & $\begin{array}{l}1=\text { No } \\
2=\text { Yes, } \\
\text { sometimes } \\
3=\text { Yes, } \\
\text { regularly }\end{array}$ \\
\hline Task demands & $\begin{array}{l}\text { 4-item scale } \\
\text { Sample item: Do you have to work very quickly? }\end{array}$ & .85 & $\begin{array}{l}1=\text { Never } \\
4=\text { Always }\end{array}$ \\
\hline \multicolumn{4}{|c|}{ Task-motivational work characteristics } \\
\hline Autonomy & $\begin{array}{l}\text { 5-item scale } \\
\text { Sample item: Can you control your own working pace? }\end{array}$ & .76 & $\begin{array}{l}1=\text { Never } \\
3=\text { Most of the } \\
\text { time }\end{array}$ \\
\hline Task variety & $\begin{array}{l}\text { 3-item scale } \\
\text { Sample item: Is your work varied? }\end{array}$ & .75 & $\begin{array}{l}1=\text { Never } \\
4=\text { Always }\end{array}$ \\
\hline \multicolumn{4}{|c|}{ Social work characteristics } \\
\hline $\begin{array}{l}\text { Social support } \\
\text { colleagues }\end{array}$ & $\begin{array}{l}\text { 4-item scale } \\
\text { Sample item: My colleagues are friendly }\end{array}$ & .83 & $\begin{array}{l}1 \text { = Strongly } \\
\text { disagree } \\
4 \text { = Strongly } \\
\text { agree }\end{array}$ \\
\hline $\begin{array}{l}\text { Social support } \\
\text { supervisor }\end{array}$ & $\begin{array}{l}\text { 4-item scale } \\
\text { Sample item: My supervisor helps to get the work done }\end{array}$ & .88 & $\begin{array}{l}1 \text { = Strongly } \\
\text { disagree } \\
4 \text { = Strongly } \\
\text { agree }\end{array}$ \\
\hline $\begin{array}{l}\text { Emotional } \\
\text { workload }\end{array}$ & $\begin{array}{l}\text { 3-item scale } \\
\text { Sample item: Is your work emotionally demanding? }\end{array}$ & .82 & $\begin{array}{l}1=\text { Never } \\
4=\text { Always }\end{array}$ \\
\hline $\begin{array}{l}\text { Contact with } \\
\text { colleagues, } \\
\text { colleagues in other } \\
\text { teams, customers } \\
\text { or suppliers }\end{array}$ & $\begin{array}{l}4 \text { separate items } \\
\text { How often are you in contact with: } \\
\text { - colleagues in your own team? } \\
\text { - colleagues in other teams, departments or at other sites? } \\
\text { - customers (or patients, students, passengers)? } \\
\text { - suppliers, subcontractors? }\end{array}$ & - & $\begin{array}{l}1=\text { Never } \\
5=\text { Daily }\end{array}$ \\
\hline
\end{tabular}




\subsubsection{Analysis}

To test Hypotheses 1, 2, 3 and 4 we estimated multiple regressions on all work characteristics under study, with older employees' educational level as an explanatory variable. In all models we include age and gender as covariates. To test Hypotheses 5, 6, 7 and 8, we estimated multiple regressions on the six dimensions of work ability (health, physical and mental work ability) and work motivation (preferred retirement age, job satisfaction and engagement). We include age and gender as covariates.

\subsection{Estimation results}

\subsubsection{Descriptive statistics and correlations}

First, Tables 6.2 and 6.3 present descriptive statistics and correlations for all variables used in the study. In our sample, $25 \%$ of all workers are less educated (ISCED up to 2). The average age of employees in the sample is $52.5 .55 \%$ are males. Neither age, nor gender, nor type of contract or hours worked differ significantly between less, intermediate and higher educated employees in the sample (not in Table 6.2).

Table 6.3 shows correlations for all variables under study. The table shows that employees' educational level and their contextual work characteristics are positively correlated. Educational level and cognitive-informational, task-informational and social work characteristics are predominantly negatively correlated. The exception is contact with suppliers, which has no significant relationship with employees' level of education.

These correlations are in line with our Hypotheses 1, 2, 3 and 4. Table 6.3 also shows negative correlations between contextual work characteristics, work ability and work motivation and predominantly positive correlations between on the one hand task-motivational and social work characteristics and work ability and on the other hand work motivation. Correlations between the cognitive-informational work characteristics and work ability and work motivation are negative (task demands and time pressure) as well as positive (job complexity). These correlations are grossly in line with the expectations from our Hypotheses 5, 6, 7 and 8. 
Table 6.2 Descriptive statistics of variables used in the study

\begin{tabular}{|c|c|c|c|}
\hline & $\mathbf{N}$ & $\%$ & \\
\hline Less educated (ISCED <3) & 4,981 & $25 \%$ & \\
\hline \multirow[t]{2}{*}{ Male } & 5,002 & $55 \%$ & \\
\hline & $\mathbf{N}$ & Mean & SD \\
\hline Age & 5,002 & 52.5 & 4.73 \\
\hline \multicolumn{4}{|l|}{ Work Ability } \\
\hline Health status & 4,968 & 3.34 & 0.84 \\
\hline Physical ability to work & 4,771 & 4.29 & 0.80 \\
\hline Mental ability to work & 4,761 & 4.32 & 0.76 \\
\hline \multicolumn{4}{|l|}{ Work Motivation } \\
\hline Preferred retirement age & 4,047 & 62.6 & 3.64 \\
\hline Job satisfaction & 4,779 & 3.86 & 0.80 \\
\hline \multirow[t]{2}{*}{ Engagement } & 4,776 & 3.17 & 0.66 \\
\hline & $\mathbf{N}$ & Mean & SD \\
\hline \multicolumn{4}{|l|}{ Contextual work characteristics } \\
\hline Dangerous work & 4,936 & 1.22 & 0.48 \\
\hline Physical strain (using force) & 4,917 & 1.47 & 0.72 \\
\hline Repetitive work & 4,806 & 1.80 & 0.87 \\
\hline Uncomfortable position & 4,740 & 1.43 & 0.66 \\
\hline \multicolumn{4}{|c|}{ Cognitive-informational work characteristics } \\
\hline Job complexity & 4,959 & 3.19 & 0.59 \\
\hline Time pressure & 4,926 & 2.23 & 0.65 \\
\hline Task demands & 4,953 & 2.36 & 0.62 \\
\hline \multicolumn{4}{|l|}{ Task-motivational work characteristics } \\
\hline Autonomy & 4,961 & 2.57 & 0.49 \\
\hline Task variety & 4,967 & 2.81 & 0.64 \\
\hline \multicolumn{4}{|l|}{ Social work characteristics } \\
\hline Social support colleagues & 4,789 & 3.22 & 0.48 \\
\hline Social support supervisor & 4,699 & 2.78 & 0.67 \\
\hline Emotional workload & 4,955 & 1.85 & 0.61 \\
\hline Contact with colleagues & 4,933 & 4.72 & 0.74 \\
\hline Contact with colleagues in other teams & 4,903 & 3.87 & 1.27 \\
\hline Contact with customers & 4,897 & 4.09 & 1.35 \\
\hline Contact with suppliers & 4,837 & 2.51 & 1.47 \\
\hline
\end{tabular}

${ }^{* * *} p<.01$ 


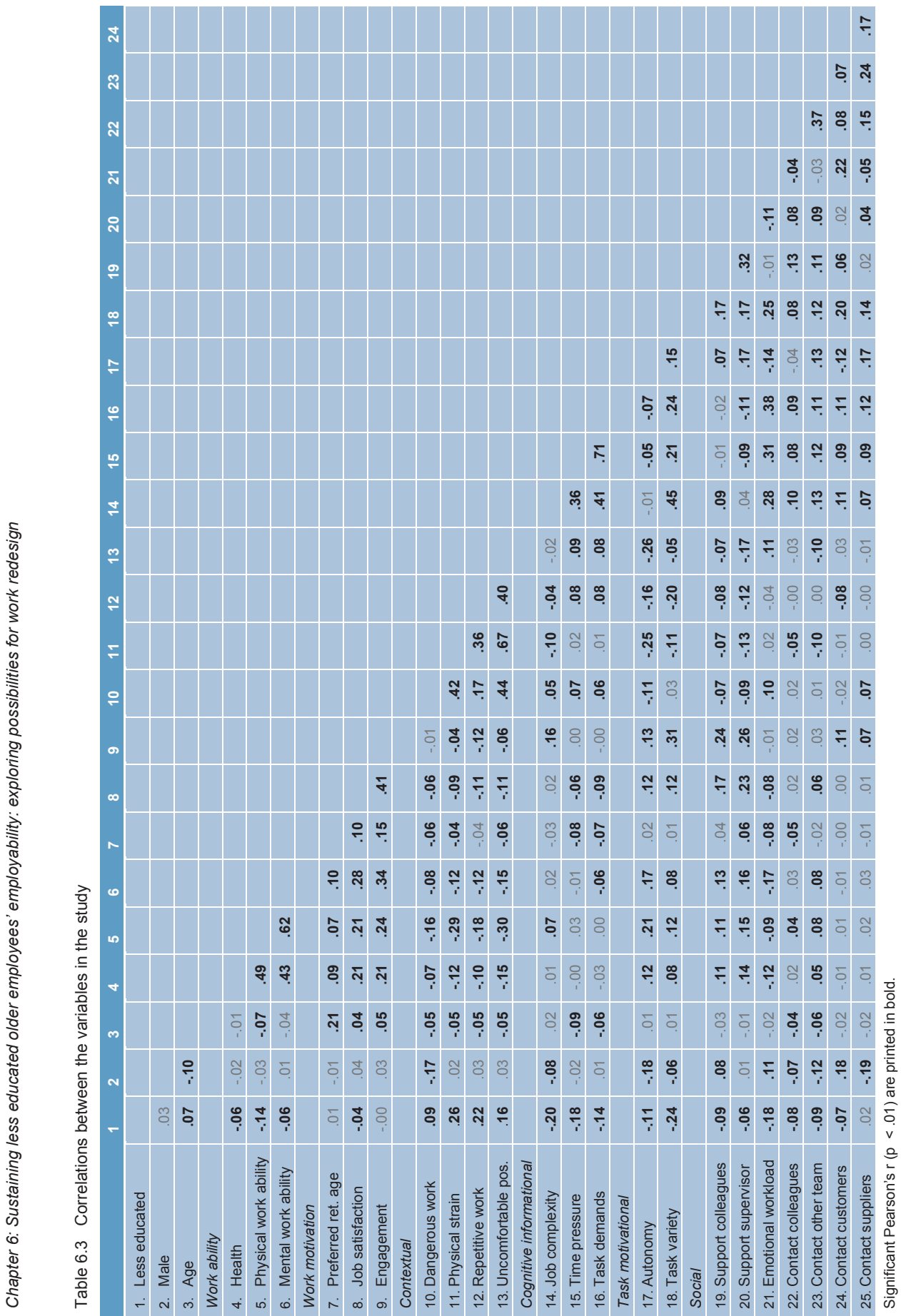




\subsubsection{Work characteristics by level of education}

Table 6.4 presents the results of our multivariate analyses of various differences in job characteristics between less and higher educated older employees (Hypotheses 1, 2, 3 and 4).

With regard to contextual characteristics, Table 6.4 shows that less educated older employees more often report dangerous work than higher educated older employees. They also more often have to use force, perform repetitive tasks and work in an uncomfortable position than higher educated older employees. These findings support Hypothesis 1: Less educated older employees face demanding contextual work characteristics more often than higher educated older workers.

Table 6.4 Multivariate regressions on differences in work characteristics between less educated and high educated workers

\begin{tabular}{|c|c|c|c|c|}
\hline & \multicolumn{3}{|c|}{ Less educated (< ISCED 3) } & \multirow[b]{2}{*}{ Adj. $\mathbf{R}^{2}$} \\
\hline & $\beta \#$ & SE & $\mathbf{N}$ & \\
\hline \multicolumn{5}{|c|}{ Contextual work characteristics 2007} \\
\hline Dangerous work & $0.11^{\star * *}$ & 0.02 & 4,915 & .04 \\
\hline Physical strain (using force) & $0.44^{\star \star *}$ & 0.02 & 4,895 & .07 \\
\hline Repetitive work & $0.44^{* * *}$ & 0.03 & 4,785 & .05 \\
\hline Uncomfortable position & $0.25^{* * *}$ & 0.02 & 4,722 & .03 \\
\hline \multicolumn{5}{|c|}{ Cognitive-informational work characteristics 2007} \\
\hline Job complexity & $-0.27^{\star \star *}$ & 0.02 & 4,937 & .05 \\
\hline Time pressure & $-0.27^{* * *}$ & 0.02 & 4,905 & .04 \\
\hline Task demands & $-0.20^{* \star *}$ & 0.02 & 4,931 & .02 \\
\hline \multicolumn{5}{|c|}{ Task-motivational work characteristics 2007} \\
\hline Autonomy & $-0.12^{* * *}$ & 0.02 & 4,939 & .05 \\
\hline Task variety & $-0.36^{* * *}$ & 0.02 & 4,945 & .06 \\
\hline \multicolumn{5}{|c|}{ Social work characteristics 2007} \\
\hline Social support colleagues & $-0.10^{* * *}$ & 0.02 & 4,770 & .01 \\
\hline Social support supervisor & $-0.10^{* \star \star}$ & 0.02 & 4,679 & .00 \\
\hline Emotional workload & $-0.26^{* * *}$ & 0.02 & 4,933 & .05 \\
\hline \multicolumn{5}{|l|}{ In contact with: } \\
\hline - colleagues in own team & $-0.12^{* * *}$ & 0.02 & 4,911 & .01 \\
\hline - other colleagues & $-0.25^{\star \star *}$ & 0.04 & 4,881 & .03 \\
\hline - customers & $-0.22^{* * *}$ & 0.04 & 4,876 & .04 \\
\hline - suppliers & 0.10 & 0.05 & 4,816 & .04 \\
\hline
\end{tabular}

For cognitive-informational work characteristics, Table 6.4 shows that, compared to higher educated older employees, less educated older employees find their jobs less complex, perceive less time pressure and find their tasks less demanding. From Table 6.4 we conclude that Hypothesis 2 is supported. Less educated older employees have lower cognitive-informational work characteristics than higher educated older employees. 
On the task-motivational work characteristics, compared to higher educated older employees, less educated older employees have jobs with less autonomy and less task variance. From Table 6.4, we therefore conclude that Hypothesis 3 is also supported. Less educated older employees have lower task-motivational work characteristics than higher educated older employees.

With regard to the social work characteristics dimension (Hypothesis 4) it is apparent that less educated older employees perceive less social support from their supervisor and colleagues. Also, less educated older employees appear to have jobs that are emotionally less demanding than higher educated older employees. Moreover, the frequency of social interactions with customers and colleagues, either from their own or another team, is lower for less educated employees. These results partially support Hypothesis 4 that less educated older employees have lower social work characteristics than higher-educated older employees.

\subsubsection{Work characteristics, work ability and work motivation}

To test Hypotheses 5 to 8, we analysed the relationships between work characteristics at T1 (2007) and less educated older employees work ability and work motivation at T2 (2008).

First, we looked at the impact of contextual work characteristics. Table 6.5 shows that less educated older employees who work in an uncomfortable position on a regular basis have a general health, lower physical ability (work ability) and are less satisfied with their job (work motivation). We find, however, no evidence of significant effects of dangerous work, physical strain (using force) or repetitive work on one of the indicators of work ability or work motivation. We therefore conclude that Hypothesis 5 is only partly supported, with only one out of four contextual work characteristics in our analysis being negatively related to the work ability and work motivation of less educated older employees.

Second, Table 6.5 shows that cognitive-informational work characteristics have little effect on the work ability and work motivation of less educated older employees. Time pressure and task demands show no relationship with the three indicators of work ability and work motivation. Job complexity only has a positive effect on less educated older employees' engagement. From Table 6.5 we therefore conclude that Hypothesis 6 is partly supported, with only job complexity being positively related to work motivation.

Third, we looked at the effects of task-motivational work characteristics on work ability and work motivation. Table 6.5 shows that autonomy is positively related with general health, physical work ability and engagement. Contrary to what we expected, however, we found a weak negative relation between the level of autonomy and the preferred retirement age. Task variety is also 
positively related to employees' physical ability to work, job satisfaction and engagement. From Table 6.5 we conclude that Hypothesis 7 is also partly supported. Both task-motivational characteristics in the study improve less educated older employees' work ability and work motivation.

To a large extent, social work characteristics have the expected effects on the work ability and work motivation of less educated older employees. Social support by colleagues and/or the supervisor has positive effects on general health, job satisfaction as well as engagement. Furthermore, social support by colleagues has positive effects on mental work ability, while social support by a supervisor contributes to physical work ability. Being involved in emotional work has the expected negative effects on less educated older employees' general health, physical and mental ability to work (work ability), as well as on their preferred retirement age (work motivation).

Finally, Table 6.5 shows that more interaction with customers positively affects less educated older workers' physical ability to work as well as their engagement. From the results in Table 6.5, we conclude that Hypothesis 8 is partly confirmed insofar as more support from management and co-workers, more client contact and less emotional workload positively influence work ability and work motivation.

Table 6.5 Regression analyses for predicting work ability and work motivation of less educated older employees

\begin{tabular}{|c|c|c|c|c|c|c|}
\hline & \multicolumn{3}{|c|}{ Work ability 2008} & \multicolumn{3}{|c|}{ Work motivation 2008} \\
\hline & $\begin{array}{c}\text { General } \\
\text { health }\end{array}$ & $\begin{array}{c}\text { Physical } \\
\text { ability to } \\
\text { work }\end{array}$ & $\begin{array}{c}\text { Mental } \\
\text { ability to } \\
\text { work }\end{array}$ & $\begin{array}{c}\text { Preferred } \\
\text { retirement } \\
\text { age } \\
\end{array}$ & $\begin{array}{c}\text { Job } \\
\text { satisfaction }\end{array}$ & Engagement \\
\hline & $\beta$ & $\beta$ & $\beta$ & $\beta$ & $\beta$ & $\beta$ \\
\hline Constant & $\begin{array}{l}2.77^{\star \star * *} \\
(0.45)\end{array}$ & $\begin{array}{l}3.87^{\star * *} \\
(0.45)\end{array}$ & $\begin{array}{l}3.96^{* * *} \\
(0.41)\end{array}$ & $\begin{array}{l}55.02^{\star * *} \\
(2.12)\end{array}$ & $\begin{array}{l}2.98^{* * *} \\
(0.45)\end{array}$ & $\begin{array}{l}0.93^{* *} \\
(0.37)\end{array}$ \\
\hline \multicolumn{7}{|l|}{ Contextual characteristics } \\
\hline Dangerous work & $\begin{array}{l}-0.09 \\
(0.05)\end{array}$ & $\begin{array}{l}-0.07 \\
(0.05)\end{array}$ & $\begin{array}{l}-.057 \\
(0.05)\end{array}$ & $\begin{array}{l}-0.22 \\
(0.26)\end{array}$ & $\begin{array}{l}-0.04 \\
(0.05)\end{array}$ & $\begin{array}{l}-0.05 \\
(0.04)\end{array}$ \\
\hline Physical strain (using force) & $\begin{array}{c}0.03 \\
(0.04)\end{array}$ & $\begin{array}{l}-0.06 \\
(0.04)\end{array}$ & $\begin{array}{l}-.016 \\
(0.04)\end{array}$ & $\begin{array}{c}0.08 \\
(0.20)\end{array}$ & $\begin{array}{c}0.03 \\
(0.04)\end{array}$ & $\begin{array}{l}-0.00 \\
(0.04)\end{array}$ \\
\hline Repetitive work & $\begin{array}{c}0.01 \\
(0.04)\end{array}$ & $\begin{array}{c}0.03 \\
(0.04)\end{array}$ & $\begin{array}{c}.004 \\
(0.03)\end{array}$ & $\begin{array}{c}0.18 \\
(0.16)\end{array}$ & $\begin{array}{c}0.02 \\
(0.03)\end{array}$ & $\begin{array}{c}0.01 \\
(0.03)\end{array}$ \\
\hline Uncomfortable position & $\begin{array}{l}-0.10^{* *} \\
(0.05)\end{array}$ & $\begin{array}{l}-0.18^{* * *} \\
(0.05)\end{array}$ & $\begin{array}{l}-.072 \\
(0.05)\end{array}$ & $\begin{array}{l}-0.05 \\
(0.23)\end{array}$ & $\begin{array}{l}-0.09^{*} \\
(0.05)\end{array}$ & $\begin{array}{l}-0.01 \\
(0.04)\end{array}$ \\
\hline \multicolumn{7}{|l|}{ Cognitive-informational char. } \\
\hline Job complexity & $\begin{array}{c}0.04 \\
(0.05)\end{array}$ & $\begin{array}{c}0.04 \\
(0.05)\end{array}$ & $\begin{array}{c}0.05 \\
(0.04)\end{array}$ & $\begin{array}{l}-0.14 \\
(0.23)\end{array}$ & $\begin{array}{c}0.04 \\
(0.05)\end{array}$ & $\begin{array}{l}0.08^{* *} \\
(0.04)\end{array}$ \\
\hline Time pressure & $\begin{array}{c}0.06 \\
(0.06)\end{array}$ & $\begin{array}{c}0.05 \\
(0.06)\end{array}$ & $\begin{array}{c}0.06 \\
(0.05)\end{array}$ & $\begin{array}{l}-0.03 \\
(0.28)\end{array}$ & $\begin{array}{l}-0.04 \\
(0.06)\end{array}$ & $\begin{array}{l}-0.01 \\
(0.05)\end{array}$ \\
\hline Task demands & $\begin{array}{c}0.04 \\
(0.06)\end{array}$ & $\begin{array}{c}0.01 \\
(0.06)\end{array}$ & $\begin{array}{l}-0.04 \\
(0.06)\end{array}$ & $\begin{array}{l}-0.36 \\
(0.30)\end{array}$ & $\begin{array}{l}-0.10 \\
(0.06)\end{array}$ & $\begin{array}{l}-0.06 \\
(0.05)\end{array}$ \\
\hline
\end{tabular}




\begin{tabular}{|c|c|c|c|c|c|c|}
\hline & \multicolumn{3}{|c|}{ Work ability 2008} & \multicolumn{3}{|c|}{ Work motivation 2008} \\
\hline & $\begin{array}{l}\text { General } \\
\text { health }\end{array}$ & $\begin{array}{c}\text { Physical } \\
\text { ability to } \\
\text { work }\end{array}$ & $\begin{array}{c}\text { Mental } \\
\text { ability to } \\
\text { work } \\
\end{array}$ & $\begin{array}{c}\text { Preferred } \\
\text { retirement } \\
\text { age } \\
\end{array}$ & $\begin{array}{c}\text { Job } \\
\text { satisfaction }\end{array}$ & Engagement \\
\hline & $\beta$ & $\beta$ & $\beta$ & $\beta$ & $\beta$ & $\beta$ \\
\hline \multicolumn{7}{|l|}{ Task-motivational char. } \\
\hline Autonomy & $\begin{array}{l}0.11^{* *} \\
(0.05)\end{array}$ & $\begin{array}{l}0.21^{* \star *} \\
(0.05)\end{array}$ & $\begin{array}{c}0.07 \\
(0.05)\end{array}$ & $\begin{array}{l}-0.45^{*} \\
(0.26)\end{array}$ & $\begin{array}{c}0.00 \\
(0.05)\end{array}$ & $\begin{array}{c}0.08^{*} \\
(0.05)\end{array}$ \\
\hline Task variety & $\begin{array}{c}0.03 \\
(0.05)\end{array}$ & $\begin{array}{l}0.10^{* *} \\
(0.05)\end{array}$ & $\begin{array}{c}0.06 \\
(0.04)\end{array}$ & $\begin{array}{c}0.20 \\
(0.22)\end{array}$ & $\begin{array}{l}0.17^{* \star *} \\
(0.05)\end{array}$ & $\begin{array}{l}0.30^{* * *} \\
(0.04)\end{array}$ \\
\hline \multicolumn{7}{|l|}{ Social relational char. } \\
\hline Social support colleagues & $\begin{array}{l}0.11^{\star *} \\
(0.06)\end{array}$ & $\begin{array}{c}0.06 \\
(0.06)\end{array}$ & $\begin{array}{l}0.11^{* *} \\
(0.05)\end{array}$ & $\begin{array}{c}0.39 \\
(0.26)\end{array}$ & $\begin{array}{l}0.12^{\star *} \\
(0.06)\end{array}$ & $\begin{array}{l}0.15^{\star \star *} \\
(0.05)\end{array}$ \\
\hline Social support supervisor & $\begin{array}{l}0.10^{\star *} \\
(0.04)\end{array}$ & $\begin{array}{c}0.07^{*} \\
(0.04)\end{array}$ & $\begin{array}{c}0.06 \\
(0.04)\end{array}$ & $\begin{array}{c}0.31 \\
(0.19)\end{array}$ & $\begin{array}{l}0.20^{* * *} \\
(0.04)\end{array}$ & $\begin{array}{l}0.18^{\star \star *} \\
(0.03)\end{array}$ \\
\hline Emotional workload & $\begin{array}{l}-0.20^{\star * *} \\
(0.05)\end{array}$ & $\begin{array}{l}-0.20^{\star * *} \\
(0.05)\end{array}$ & $\begin{array}{l}-0.25^{\star \star *} \\
(0.05)\end{array}$ & $\begin{array}{l}-0.55^{* *} \\
(0.24)\end{array}$ & $\begin{array}{l}-0.03 \\
(0.05)\end{array}$ & $\begin{array}{l}-0.06 \\
(0.04)\end{array}$ \\
\hline \multicolumn{7}{|l|}{ In contact with: } \\
\hline - colleagues & $\begin{array}{c}0.01 \\
(0.04)\end{array}$ & $\begin{array}{l}-0.02 \\
(0.04)\end{array}$ & $\begin{array}{l}-0.04 \\
(0.03)\end{array}$ & $\begin{array}{l}-0.20 \\
(0.17)\end{array}$ & $\begin{array}{l}-0.04 \\
(0.04)\end{array}$ & $\begin{array}{l}-0.04 \\
(0.03)\end{array}$ \\
\hline - colleagues other teams & $\begin{array}{l}-0.01 \\
(0.02)\end{array}$ & $\begin{array}{l}-0.01 \\
(0.02)\end{array}$ & $\begin{array}{c}0.01 \\
(0.02)\end{array}$ & $\begin{array}{c}0.02 \\
(0.10)\end{array}$ & $\begin{array}{c}0.03 \\
(0.02)\end{array}$ & $\begin{array}{l}-0.02 \\
(0.02)\end{array}$ \\
\hline - customers & $\begin{array}{c}0.03 \\
(0.02)\end{array}$ & $\begin{array}{l}0.06^{\star \star *} \\
(0.02)\end{array}$ & $\begin{array}{c}0.03 \\
(0.02)\end{array}$ & $\begin{array}{l}-0.01 \\
(0.09)\end{array}$ & $\begin{array}{l}-0.03 \\
(0.02)\end{array}$ & $\begin{array}{l}0.03^{* *} \\
(0.02)\end{array}$ \\
\hline - suppliers & $\begin{array}{l}-0.02 \\
(0.02)\end{array}$ & $\begin{array}{l}-0.02 \\
(0.02)\end{array}$ & $\begin{array}{c}0.00 \\
(0.02)\end{array}$ & $\begin{array}{l}-0.06 \\
(0.09)\end{array}$ & $\begin{array}{l}-0.02 \\
(0.02)\end{array}$ & $\begin{array}{c}0.00 \\
(0.02)\end{array}$ \\
\hline \multicolumn{7}{|l|}{ Control variables } \\
\hline Age & $\begin{array}{l}-0.01 \\
(0.01)\end{array}$ & $\begin{array}{l}-0.01^{*} \\
(0.01)\end{array}$ & $\begin{array}{l}-0.00 \\
(0.01)\end{array}$ & $\begin{array}{l}0.16^{\star * *} \\
(0.03)\end{array}$ & $\begin{array}{c}0.00 \\
(0.01)\end{array}$ & $\begin{array}{l}0.01^{*} \\
(0.01)\end{array}$ \\
\hline Gender (ref = male) & $\begin{array}{l}-0.04 \\
(0.06)\end{array}$ & $\begin{array}{c}0.06 \\
(0.06)\end{array}$ & $\begin{array}{l}0.11^{* *} \\
(0.05)\end{array}$ & $\begin{array}{c}0.37 \\
(0.29)\end{array}$ & $\begin{array}{c}0.05 \\
(0.06)\end{array}$ & $\begin{array}{c}0.08 \\
(0.05)\end{array}$ \\
\hline Adj. $R^{2}$ & .05 & .13 & .08 & .07 & .10 & .20 \\
\hline $\mathrm{N}$ & 943 & 904 & 903 & 736 & 908 & 906 \\
\hline
\end{tabular}

${ }^{*} p<.10,{ }^{* *} p<.05,{ }^{* * *} p<.01$

Standard errors in parentheses.

\subsection{Conclusions}

This study aimed to explore directions for redesigning less educated older employees' work in order to increase their work ability and work motivation. In the study we addressed three related research questions:

1. How do work characteristics of less educated older employees differ from older employees with higher levels of education?

2. Which work characteristics of less educated older employees are related to their work ability and work motivation? 
3. What characteristics of less educated older employees' work are particularly promising for work redesign?

\subsubsection{Work characteristics and relationships with work ability and work motivation (research questions 1 and 2)}

To answer the first two questions we tested eight hypotheses using data from the Netherlands Working Conditions Cohort Study (NWCCS). Four hypotheses are on the differences in work characteristics between less educated and higher educated older employees and four hypotheses are on the effects work characteristics have on less educated older employees' work ability and work motivation. We find support for our hypothesis that less educated older employees have more demanding contextual work characteristics (dangerous work, physical strain, repetitive work and working in an uncomfortable position) than higher educated older employees. These results are in line with earlier findings by for instance Parent-Thirion et al., (2005). Next, we find that the contextual work characteristic 'working in an uncomfortable position' negatively affects less educated older employees' work ability as well as their work motivation. These results suggest that in order to improve the work ability and work motivation of less educated older employees, redesigning their work through decreasing the amount of time spent in an uncomfortable position, may be promising for extending their working lives.

We also find support for our hypothesis that less educated older employees have lower cognitiveinformational work characteristics (job complexity, time pressure and task demands) than higher educated older employees. These findings confirm earlier findings by for instance Morgeson and Humphrey (2006). However, we find cognitive-informational work characteristics to have no effect on the work ability of less educated older employees and there is only a weak positive effect of job complexity on engagement as an indicator of work motivation.

From these results we conclude that there is no reason to focus on cognitive-informational work characteristics such as a decrease or an increase in job complexity, time pressure or task demands, when redesigning less educated older employees work in order to extend their working lives.

Third, we find support for our hypothesis that less educated older employees have fewer taskmotivational work characteristics (autonomy and task variety), than higher educated older employees. These results also confirm earlier findings by Morgeson and Humphrey (2006). We find that most task-motivational work characteristics under study have positive effects on less educated older employees' work ability and work motivation. Contrary to what we expected, however, autonomy has a weak but significant negative effect on less educated older employees' 
preferred retirement age, instead of a positive effect. More autonomy might therefore predict a preference for earlier retirement, instead of work life extension. This contradicts earlier findings by Quinn (1978) and Holte et al. (2000), who found positive associations between low autonomy jobs and early retirement. They did not control for educational level or income, which may explain the different results. We suggest low autonomy may have a different relationship with the preferred retirement age for less educated employees than for higher educated employees. Less educated employees in low autonomy jobs most likely earn a relatively low income and therefore simply cannot afford to retire early. Less educated employees with high autonomy jobs are likely to earn more and can afford to retire early and prefer to do so. For higher educated employees the opposite may be true in that higher educated employees in low autonomy jobs can financially afford to retire early from their relatively unappealing job. Higher educated employees in high autonomy jobs have the possibility to change their job in a way that it remains interesting, which will prevent them from retiring early. Thus, among less educated employees autonomy may be negatively related to the preferred retirement age (which we find) and among higher educated employees autonomy may be positively related to the preferred retirement age. On the basis of these findings, we suggest that redesigning task-motivational characteristics of work, more specifically, an increase in task variety, could be a promising HR practice.

Finally, we find substantial support for our hypothesis that less educated older employees have fewer social work characteristics (social support by colleagues or supervisor, emotional work and contact with customers) than higher educated older employees. The results confirm earlier findings by Parent-Thirion et al. (2005). We also find that having more social work characteristics have positive effects on less educated older employees' work ability as well as their work motivation. More specifically, we find that more social support by colleagues and supervisors, more contact with customers and less emotional workload contribute to less educated older employees' work ability and work motivation. These findings suggest that redesigning social work characteristics, more specifically: give more support, enable customer contact and lower the emotional workload, could be promising directions for the extension of less educated older workers working lives.

\subsubsection{Work redesign possibilities (research question 3)}

The results of our empirical analyses present HR practitioners with directions for redesigning less educated older employees' work in order to extend their working lives. Based on our findings we advise developing Active Ageing policies to include work redesign. We stress, however, that work redesign should be undertaken carefully and with a focus on those work characteristics that are shown to actually affect less educated older employees' work ability and/or work motivation. For instance, Table 6.6 contains the work characteristics that less educated older employees scored 
less favourably on compared to higher-educated older employees. For these work characteristics there is probably room for improvement, at least in the sense of closing the gap between less and higher educated employees as much as possible. Next, the number of indicators that a certain work characteristic has a desirable or undesirable effect upon, are in parentheses. For instance, job complexity has a desirable positive effect on work engagement and no effect on any of the three indicators for work ability. The upper right cell in Table 6.6 shows the work characteristics that have desirable effects on both work ability and work motivation. These work characteristics are probably the most promising ones for work redesign aimed at improving less educated older employees' work ability and work motivation.

The upper right cell in Table 6.6 shows that redesign strategies aimed at increasing social support from either colleagues or supervisors is a promising direction for a firm's HR policy. Improving peer support shows desirable effects on work ability and work motivation. In addition, a decrease in the emotional workload of less educated older employees has desirable effects on their work ability and motivation. We could, therefore, conclude that 'social work redesigns' are likely to lead to an increase in the ability and motivation of less educated older employees which might contribute to extending their working lives.

Table 6.6 Promising and less promising work redesign strategies

\begin{tabular}{|c|c|c|c|}
\hline & Only ability & Only motivation & Ability and motivation \\
\hline Desirable effect & - None & - Job complexity (1) & $\begin{array}{l}\text { - Social support colleagues (4) } \\
\text { - Social support supervisor (4) } \\
\text { - Emotional workload (4) } \\
\text { - Autonomy (3) } \\
\text { - Task variety (3) } \\
\text { - Uncomfortable position (3) } \\
\text { - Customer contact (2) }\end{array}$ \\
\hline No effect & - Job complexity & - None & $\begin{array}{l}\text { - Dangerous work } \\
\text { - Physical strain (using force) } \\
\text { - Repetitive work } \\
\text { - Time pressure } \\
\text { - Task demands }\end{array}$ \\
\hline Undesirable effect & - None & $\begin{array}{l}\text { - Autonomy (1) } \\
\text { (retirement age) }\end{array}$ & - None \\
\hline
\end{tabular}

Addressing the benefits of social work characteristics in lower-skilled jobs, Leana et al. (2009) focused on the outcomes of collaborative job crafting in American childcare centres where teachers collectively made adjustments to their work in order to meet their shared objectives. Leana et al. (2009) demonstrated that the extent to which employees could adjust their work contributed to their job satisfaction and organizational commitment as well as to the quality of 
childcare. Organizations could, therefore, experiment with involving less educated employees in crafting their own work characteristics to match their needs and aspirations. In addition to these findings, Borghans et al. (2009) have demonstrated that in the workplace human capital is mainly built through interaction with colleagues and supervisors. An increase in support from colleagues and supervisors might therefore also foster employees' skill development, which will enhance the work ability of less educated older employees. These latter relationships, however, need to be studied more closely. 


\section{Impact on skill shortages}




\section{Chapter 7: Impact of developmental, mobility and work redesign activities on skills shortages ${ }^{8}$}

\subsection{Introduction}

Ongoing technological and organizational changes have caused continuous shifts in the demand for skills in the labour market (Bresnahan, Brynjolfsson, \& Hitt, 2002; Brynjolfsson \& McAfee, 2014; Goos, Manning, \& Salomons, 2014). These shifts have caused at least some skills to become obsolete (De Grip \& Van Loo, 2001). Pillay (1998), Marsick and Watkins (2001) and Sanders and Kraan (2013) show that organizational change is correlated with employees perceiving skills mismatches. Allen and Van der Velden (2002) add that the speed with which organizational change is implemented increases skills mismatch. Skills mismatch, more specifically skills shortage, has been shown to have detrimental effects on productivity, job security and employability (De Wit, 2005; Allen \& De Grip, 2006; Weiss \& Garloff, 2009; Sanders \& Kraan, 2013). These findings are in line with predictions made in Person-Job Fit Theory (PJF: Kristof, 1996) and Job Matching Theory (JMT: Jovanovich, 1979) as introduced and discussed in Chapter 2 of this thesis. Repairing and preventing skills shortage is crucial in terms of sustaining employability and restoring a worker's productivity. This particularly holds for less educated employees, since they have been shown to generally have a more fragile employability (Sanders et al., 2011a) and even more for less educated employees aged 45 or over, since they often perceive skills shortages because of ICT related organisational change (Borghans \& Ter Weel, 2002; Kooij-de Bode \& De Looze, 2008). Fouarge, De Grip and Montizaan (2011) also show that according to their employers, older employees in the public sector are perceived as being less competent and less able to handle organizational and technological change. These findings underline the importance of finding effective ways of sustaining less educated older employees' employability in order to have them remain active in the labour market at least until the age of 65 or older. Literature on what effective ways of sustaining less educated older employees' employability are, is however, rather scarce.

In this thesis we introduced three categories of actions that might improve less educated older employees' employability (see Chapter 2): development, mobility and work redesign.

8 This chapter is based on: Sanders, J., Blonk, R., Geuskens, G. \& de Grip, A. (2015). Achter de feiten aan leren, onderzoek onder laaggeschoolde oudere werknemers naar het effect van leeractiviteiten op de kans te herstellen van een kennistekort [Training or trailing; a study into the effects of developmental activities on skills shortage recovery]. Tijdschrift voor Arbeidsvraagstukken, 31(3), 292-313. 
These routes have been explored in the preceding chapters: development (Chapters 3 and 4), mobility (Chapter 5) and work redesign (Chapter 6). In this chapter, we analyse whether specific actions on these three routes are effective in that they help employees recover from perceived skills shortage.

This study is the first to use longitudinal data to analyse the relationship between less educated older employees actions to sustain their employability and their perceived skills shortages. In line with predictions of Person-Job Fit theory (PJF) and Job Matching Theory (JMT), we find that substantial training helps less educated older employees to recover from perceived skills shortage and in that sense contributes to their sustainable employability. Also in line with PJF and JMT predictions we find that organisational instability has negative effects on less educated older employees' chances to recover from perceived skills shortage. Contrary to what we would expect based on PJF and JMT predictions, however, we do not find empirical support for our hypotheses that instructions or shorter training spells increase less educated older employees' chances of recovering from perceived skills shortage. Also, we do not find empirical support for our hypotheses that mobility and work redesign have positive effects on less educated older employees' chances of recovering from perceived skills shortage.

The remainder of this chapter is structured as follows: Section 7.2 briefly describes PJF and JMT as the conceptual framework for the study and introduces our hypotheses. In section 7.3 we discuss the method and data used for this study. In section 7.4 we present estimation results and section 7.5 concludes.

\subsection{Theoretical background and hypotheses}

To answer the question whether less educated older employees' skills shortage can be recovered through skills development, mobility or work redesign, we take Kristof's dynamic concept of Person-Organization or Person-Job fit (PJF; Kristof, 1996) and Jovanovich's Job Matching theory (JMT; Jovanovich, 1979) as our theoretical starting points. Both JMT and PJF describe the dynamic process of skills (mis)match and its relation to productivity. Central to both theories is that organizational and technological changes lead to shifts in the demand for skills, causing an increase in skills (mis)match.

Development activities, such as instruction and training, are supposed to develop the skills workers can supply so that they can rematch their skills supply to the shifts in skills demand. Mobility, i.e., promotion, demotion or job change, is supposed to relocate employees' skills to a job that better matches their skills. Finally, work redesign, such as job enlargement, task changes 
or job enlightenment, is supposed to improve the skill match by adapting the skills demanded in the job to the skills that an employee can supply. If a skills rematch is reached, JMT speaks of a 'productive job match' and PJF speaks of a 'demands-abilities fit'. Both job match and D-A fit are, however, related to higher productivity levels and to sustainable rather than fragile employability.

In this study, on the basis of JMT and PJF, we hypothesize that less educated older employees who participate in development, mobility or work redesign activities are more likely to recover from perceived skills shortage than less educated older employees who do not participate in such activities. This leads to the following three hypotheses:

Hypothesis 1: Less educated older employees who participate in development activities are more likely to recover from perceived skills shortage than less educated older employees who do not.

Hypothesis 2: Less educated older employees who participate in mobility activities are more likely to recover from perceived skills shortage than less educated older employees who do not.

Hypothesis 3: Less educated older employees who participate in work redesign activities are more likely to recover from perceived skills shortage than less educated older employees who do not.

\subsection{Method}

\subsubsection{Data, participant and procedure}

In this study we use longitudinal data from the longitudinal Study on Transition in Employment, Ability and Motivation (STREAM). In STREAM, a stratified sample of Dutch 'older' citizens aged 45-64 years complete annual online questionnaires on health, job and personal characteristics, work ability, productivity and transitions in employment.

STREAM is a longitudinal study with a large sample that not only contains data on several learning and training activities and labour market transitions such as job-to-job mobility and work redesign, but also on perceived skills mismatch. For this study we use STREAM data from employees who participated in the 2010, 2011 and 2012 waves of the study. In 2010, a total of 12,055 employees participated. Of these 12,055 employees, 8,061 participated again as an employee in 2011. In the third wave (2012) 7,379 of these employees again responded as an employee. A non-response analysis shows that none of the variables we use is significantly affected by panel attrition. See Table 7.1 for a detailed sample description. 


\subsubsection{Variables}

Perceived skills shortage was measured by asking employees to respond to the statement: 'I lack new knowledge that, because of changes in my job, has become more important in my job'. Employees were asked whether they strongly agreed, agreed, neither agreed nor disagreed, disagreed or strongly disagreed with these statements. We then dichotomized the variable. If an employee agrees or strongly agrees with the statement we consider him or her to perceive a skills shortage. Next, we constructed a skills rematch variable, based upon the measurement of perceived skills shortage. The variable measures whether employees who perceived a skills shortage at T1 (2010) still perceive a skills shortage at T3 (2012) or not. This variable thus indicates 'skills shortage recovery' versus 'continuous skills shortage' from 2010 to 2012.

Whether employees have taken the development route was measured by asking employees whether or not they participated in one or more types of training in the period 2010-2012 $(\mathrm{T} 1 \rightarrow \mathrm{T} 3)$. Possible answers were: on the job training, 1-5 days of training, more than 5 days of training, visiting a seminar or conference, meeting with a supplier and none. We include participation in (1) on the job training, (2) 1-5 days of training and (3) more than 5 days of training. Employees who have only visited a meeting with a supplier or who have visited a seminar, although possibly a 'learning experience', are not considered to have taken part in development activities.

Whether employees have taken the mobility route was measured by asking employees whether they (1) changed jobs (yes/no), (2) got a promotion (yes/no) or (3) were demoted (yes/no) at least once between 2010 and $2012(\mathrm{~T} 1 \rightarrow \mathrm{T} 3)$.

Finally, whether employees have taken the work redesign route in sustaining employability was measured by asking employees whether their job had changed in the sense that they (1) got fewer tasks (yes/no), (2) got more tasks (yes/no) or (3) got different tasks (yes/no) between 2010$2012(\mathrm{~T} 1 \rightarrow \mathrm{T} 3)$.

Since we are interested in differences between less educated and higher educated older employees we include employees' educational attainment in all our models as a dummy variable referring to less educated older employees (up to ISCED 2) and higher educated older employees (ISCED 3 or higher).

Gender, age and type of contract were introduced as control variables. Gender is measured by distinguishing men and women, the latter being the reference category. Age at baseline (2010) is included as a dummy variable referring to employees aged 45-54 (reference category) and 
employees aged 55-64. Type of contract at baseline is included as a dummy variable referring to employees with a permanent contract and employees with other contracts (reference category).

Since skills mismatch and the chances of skills rematch depend upon organizational factors (Sanders \& Kraan, 2013) we also include company size, 13 sectors of industry and a measure for organizational stability. Dummy variables were included for small (1-49 employees), medium (50249 employees) and large firm size (250 or over).

Organizational stability is measured at three waves by one item: Has there been an organizational restructuring at your work place within the last 12 months? This item contains three categories: '1' Yes, with layoffs, '2' Yes without layoffs and '3' No. A gross organizational stability score has been derived from these scores as follows: if respondents indicate there has been no restructuring at all three waves, gross organizational stability 2009-2012 is 0 'Stable'. If there has been a restructuring at one wave the score is 1 'Slightly unstable' or 'some restructuring'. If there have been restructures at two waves the score is 2 'Unstable' or 'regular restructuring' and if there have been restructures at all three waves the score is 3 'Highly unstable' or 'continuous restructuring'. Whether there were layoffs or not is not taken into account, since our primary interest is to measure organizational stability in terms of changes in the workplace.

\subsubsection{Analysis}

We start by using crosstabs and Pearson chi-square analyses for testing bivariate relations between perceived skills rematch and our explanatory and control variables. Next, to test Hypotheses 1, 2 and 3, we estimate nine logistic regression models on perceived skills rematch with three development, three mobility and three work redesign activities as explanatory variables. We estimate regression models for the following nine activities, respectively: Training/instruction on the job (DEV1), Training/education for 1-5 days (DEV2), Training/education more than 5 days (DEV3), Changing jobs/function (MOB1), Promotion (MOB2), Demotion (MOB3), Fewer tasks (WR1), More tasks (WR2) and Different tasks (WR3). We include educational attainment, age, gender, type of contract, organisational stability, sector of industry and company size as covariates in all models. ${ }^{9}$ Finally, in every model, we include an interaction term (less educated*activity participation) to see whether activities are as effective for less educated older employees as for higher educated older employees. Explanatory variables were centred and product terms were computed thereafter in order to reduce the impact of multicollinearity.

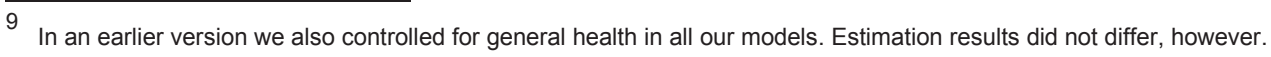




\subsection{Estimation results}

\subsubsection{Descriptives}

Table 7.1 presents a detailed description of our sample.

Table 7.1 Sample descriptives

\begin{tabular}{|c|c|c|c|}
\hline \multicolumn{2}{|c|}{ 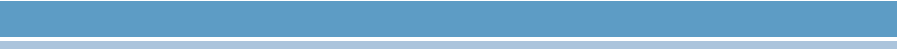 } & $\%$ & $\mathbf{N}$ \\
\hline \multicolumn{2}{|c|}{ Perceived skills shortage (at baseline 2010) $(\mathrm{N}=7,346)$} & 18 & 1,342 \\
\hline \multicolumn{2}{|c|}{ Recovery (2012) from perceived skills shortage $(2010)(N=1,342)$} & 31 & 419 \\
\hline \multicolumn{2}{|c|}{ Male $(2010)(N=7,379)$} & 56 & 4,140 \\
\hline \multicolumn{2}{|c|}{ Less educated $($ ISCED < 3) $(2010)(\mathrm{N}=7,379)$} & 26 & 1,948 \\
\hline \multirow{2}{*}{$\begin{array}{l}\text { Age }(\text { Mean }=53,6)(2010) \\
(N=7,379)\end{array}$} & $45-55$ & 54 & 4,014 \\
\hline & $55-64$ & 46 & 3,365 \\
\hline Vast contract $(2010)(N=7,360)$ & Permanent & 92 & 6,771 \\
\hline \multirow{13}{*}{$\begin{array}{l}\text { Sector of industry }(2010) \\
(N=7,206)\end{array}$} & Agriculture & 1 & 36 \\
\hline & Industry and energy & 11 & 764 \\
\hline & Construction & 3 & 223 \\
\hline & Trade & 8 & 598 \\
\hline & Transportation & 8 & 569 \\
\hline & Hotels, restaurants and bars & 1 & 65 \\
\hline & ICT & 4 & 303 \\
\hline & Finance & 4 & 295 \\
\hline & Business & 7 & 533 \\
\hline & Government & 15 & 1,074 \\
\hline & Education & 14 & 973 \\
\hline & Health and well-being & 21 & 1,499 \\
\hline & Culture & 4 & 281 \\
\hline \multirow{3}{*}{$\begin{array}{l}\text { Company size }(2010) \\
(\mathrm{N}=7,258)\end{array}$} & Small (1-49) & 28 & 2,054 \\
\hline & Middle (50-249) & 26 & 1,916 \\
\hline & Large $(250+)$ & 45 & 3,288 \\
\hline \multirow{4}{*}{$\begin{array}{l}\text { Organisational stability } \\
(2009-2012) \\
(N=7,336)\end{array}$} & Stable & 43 & 3,169 \\
\hline & Slight unstable (restructured once) & 24 & 1,768 \\
\hline & Unstable (restructured twice) & 18 & 1,328 \\
\hline & Highly unstable (continuous restructuring) & 15 & 1,064 \\
\hline \multirow{4}{*}{$\begin{array}{l}\text { Development activities } \\
(2010-2012) \\
(\mathrm{N}=7,379)\end{array}$} & DEV1 Instructions/ training on the job $(\mathrm{N}=7,379)$ & 67 & 4,944 \\
\hline & DEV2 Training or education $1-5$ days $(\mathrm{N}=7,379)$ & 47 & 3,468 \\
\hline & DEV3 Training or education $>5$ days $(\mathrm{N}=7,379)$ & 10 & 723 \\
\hline & DEV1, DEV2 and/or DEV3 (N=7,379) & 77 & 5,645 \\
\hline \multirow{4}{*}{$\begin{array}{l}\text { Mobility activities } \\
(2010-2012) \\
(\mathrm{N}=7,042)\end{array}$} & MOB1 Job change (internal mobility) $(\mathrm{N}=6,951)$ & 15 & 1,075 \\
\hline & MOB2 Promotion $(\mathrm{N}=7,342)$ & 8 & 573 \\
\hline & MOB3 Demotion $(\mathrm{N}=6,805)$ & 8 & 538 \\
\hline & MOB1, MOB2 and/or MOB3 ( $\mathrm{N}=7,042)$ & 23 & 1,627 \\
\hline \multirow{4}{*}{$\begin{array}{l}\text { Work Redesign activities } \\
(2010-2012) \\
(\mathrm{N}=7,379)\end{array}$} & WR1 Fewer tasks $(\mathrm{N}=7,379)$ & 9 & 679 \\
\hline & WR2 More tasks ( $\mathrm{N}=7,379)$ & 38 & 2,789 \\
\hline & WR3 Different tasks $(\mathrm{N}=7,379)$ & 29 & 2,110 \\
\hline & WR1, WR2 and/or WR3 $(\mathrm{N}=7,250)$ & 55 & 3,959 \\
\hline
\end{tabular}


Of the 7,346 respondents, $18 \%$ perceived skills shortage at baseline (T1: 2010). Of these 1,342 employees, 31\% have recovered from an earlier perceived skills shortage at T3 (2012). Table 7.1 also shows that on average respondents are 53,6 years old at baseline; $56 \%$ are male and $26 \%$ are less educated (ISCED $<3$ ).

Table 7.1 shows that $77 \%$ participated in development activities between T1 (2010) and T3 (2012), either receiving instructions or training on the job (67\%), participating in short training spells lasting 1-5 days (47\%) and/or participating in substantial training that lasted more than 5 days $(10 \%)$, or a combination of these different modes of learning. About a quarter $(23 \%)$ of all respondents were mobile, either through changing jobs $(15 \%)$ or getting promoted $(8 \%)$ or demoted ( $8 \%$ ) within the firm where they are employed, or a combination of these different modes of mobility. About $63 \%$ experienced work redesign, either performing fewer (9\%), more (38\%) or different tasks $(29 \%)$ or a combination.

\subsubsection{Bivariate relations}

Table 7.2 shows the percentage of less educated older workers aged 45-64 who, at T3 (2012), state to have recovered from skills shortages perceived at baseline T1 (2010). Overall, $31 \%$ of those workers who perceived skills shortages at T1, states to have recovered at T3.

Results further indicate that taking part in substantial training courses of 5 days or more increases the chances of recovering from a perceived skills shortage. We do, however, not find any significant relationships between the other development activities and skills shortage recovery probabilities. Next, looking at mobility and work redesign activities, Table 7.2 shows that older employees who change jobs, get demoted or fewer, more or different tasks are less likely to recover from a skills shortage they perceived at $\mathrm{T} 1$. Whether employees get promoted does not make a difference for skills rematch probabilities.

The analyses also reveal that less educated employees are more likely to recover from a perceived skills shortage than higher educated employees, and that male employees are less likely to recover than female employees. Also, employees in highly unstable organizations are less likely to recover from a perceived skills shortage than employees in more stable organizations. Employees in construction and health and well-being are significantly more likely to recover than employees in other sectors of industry and employees in the ICT sector are significantly less likely to recover. We also find that employees in small companies (1-49 employees) are more likely to recover from a perceived skills shortage than employees in large companies (250+ employees). 
Table 7.2 Probability of recovery from skills shortage

\begin{tabular}{|c|c|c|}
\hline & $\%$ & $\mathbf{N}$ \\
\hline Total & 31 & 1,342 \\
\hline Male employee (2010) & $27^{* * *}$ & 775 \\
\hline Less educated (ISCED < 3) (2010) & $40^{* * *}$ & 295 \\
\hline \multicolumn{3}{|l|}{ Age (2010) } \\
\hline $45-55$ & 30 & 816 \\
\hline $55-64$ & 33 & 526 \\
\hline Permanent contract (2010) & 31 & 1,213 \\
\hline \multicolumn{3}{|l|}{ Organizational instability (2009-2012) } \\
\hline Stable & $38^{* * *}$ & 490 \\
\hline Slight unstable (restructured once) & 34 & 325 \\
\hline Unstable (restructured twice) & 28 & 287 \\
\hline Highly unstable (continuous restructuring) & $17^{* * *}$ & 231 \\
\hline \multicolumn{3}{|l|}{ Sector of employment (2010) } \\
\hline Agriculture & . & 4 \\
\hline Industry and energy & 27 & 163 \\
\hline Construction & $51^{* * *}$ & 41 \\
\hline Trade & 31 & 95 \\
\hline Transportation & 35 & 69 \\
\hline Hotels, restaurants and bars & 27 & 11 \\
\hline ICT & $16^{* * *}$ & 67 \\
\hline Finance & 39 & 51 \\
\hline Business & 32 & 92 \\
\hline Government & 27 & 203 \\
\hline Education & 27 & 204 \\
\hline Health and well-being & $40^{* * *}$ & 270 \\
\hline Culture & 25 & 40 \\
\hline \multicolumn{3}{|l|}{ Company Size (2010) } \\
\hline Small (1-49) & $36^{\star *}$ & 340 \\
\hline Middle (50-249) & 31 & 364 \\
\hline Large $(250+)$ & $28^{* *}$ & 622 \\
\hline Development (2010-2012) (instruction and/or short/long training) & 32 & 1,040 \\
\hline Instructions or training on the job & 31 & 917 \\
\hline Training or education $1-5$ days & 32 & 642 \\
\hline Training or education $>5$ days & $40^{* *}$ & 151 \\
\hline Mobility (2010-2012) (job change, promotion and/or demotion) & $24^{* * *}$ & 356 \\
\hline Job change (internal mobility) & $25^{* * *}$ & 234 \\
\hline Promotion & 31 & 111 \\
\hline Demotion & $16^{* * *}$ & 129 \\
\hline Work Redesign (2010-2012) (fewer, more and/or different tasks) & $27^{* \star *}$ & 833 \\
\hline Fewer tasks & $21^{* * *}$ & 174 \\
\hline More tasks & $27^{* * *}$ & 581 \\
\hline Different tasks & $25^{\star \star *}$ & 480 \\
\hline
\end{tabular}

Note:Percentages are row percentages tested with the Pearson $x$ test (vertical comparisons). The contrast is each subgroup vs all other cases (weighted deviation contrast). ${ }^{*}$ : $<0.10^{* *}: p<0.05^{* * *}: p<0.01$ : Significant high (low) percentage (2-tailed tests). 


\subsubsection{Multivariate analyses}

Whether the results presented in Table 7.2 also specifically hold for less educated older workers, in comparison to higher educated older workers, is tested using multivariate logistic regression analyses on employees' skills rematch probabilities at T3 after perceiving a skills shortage at T1. In all models we include our control variables (educational attainment, age, gender, type of contract, organizational stability, sector of employment and company size). Interaction terms (development, mobility, work redesign activities $*$ less educated) are included to test whether the relationships found differ between less and higher educated employees. Table 7.3 presents the results for Hypothesis 1 (development activities), whereas the Tables 7.4 and 7.5 present the results for Hypotheses 2 (mobility activities) and 3 (work redesign activities), respectively.

On Hypothesis 1, suggesting that less educated older employees who take part in development activities are more likely to recover from perceived skills shortage, Table 7.3, column (1), shows a marginal positive effect of taking part in one or more developmental activities on skills shortage recovery $(\operatorname{Exp}(B)=1.37 ; p<.10)$. Older employees who participated in one or more of the three development activities are 1.37 times more likely to recover from a perceived skills shortage. Including the interaction term for level of education (Development activity $*$ less educated) in our model does not explain significant amounts of additional variance. Less educated and higher educated older employees seem to equally benefit from taking part in development activities in terms of recovering from a perceived skills shortage. The logistic regression model for development activities in general (column 1$)$ is statistically significant $\left(\chi^{2}=89.09 ; p<.01\right)$ but explains $10 \%$ (Nagelkerke $R^{2}$ ) of the variance in skills shortage recovery probability.

Next, we examine the effects of the different learning activities through three separate logistic regression models on skills shortage recovery, with 'instructions at work' (column 2), 'up to 5 days of training' (column 3 ) and 'training for more than 5 days (column 4), respectively. We find a marginal positive effect of taking part in up to 5 days of training $(\operatorname{Exp}(B)=1.29 ; p<.10)$ and a strong significant positive effect of taking part in training for more than 5 days $(\operatorname{Exp}(B)=1.79 ; p<$ .01). We did not find a significant effect of getting instructions at work.

We conclude that older employees who participated in up to five days of training are 1.29 times more likely and those who participated in more than 5 days of training are even 1.79 times more likely to recover from a perceived skills shortage than those who don't participate in one of these activities. The interaction terms for level of education (Dev1 * less educated, etc.) in our respective models are not significant. This suggests that less educated older employees and higher educated older employees equally benefit from taking part in development activities. The 
logistic regression models (2), (3) and (4) are all statistically significant and explain between 9 and $10 \%$ of the variance (Nagelkerke $R^{2}$ ) in skills shortage recovery probability.

On Hypothesis 2, column (1) in Table 7.4 shows a small but significant negative effect $(\operatorname{Exp}(B)=$ $0.73 ; p<.05)$ of mobility on skills shortage recovery. Older employees who take part in one or more of the three mobility activities are less likely to recover from perceived skills shortage than older employees who do not take part in these activities. The interaction term for level of education (mobility activity $*$ less educated) is not significant. The logistic regression model for mobility activities in general $(1)$ is statistically significant $\left(\chi^{2}=85.23 ; p<.01\right)$ and explains $10 \%$ (Nagelkerke $R^{2}$ ) of the variance in skills shortage recovery probability.

Next, we examine the effects of the three specific mobility activities. We do not find a significant effect of job change and promotion on skills shortage recovery probabilities (Table 7.4, columns 2 and 3). We do, however, find a strong negative effect of demotion on skills shortage recovery $(\operatorname{Exp}(B)=0.36 ; p<.01)($ Table 7.4 , column 4). Older employees who are demoted are less likely to recover from a perceived skills shortage than older employees who are not. This result is the opposite of what we expected.

The significant interaction term Mob1 $*$ less educated in model 2 (job change) shows that less educated older employees who change jobs are significantly less likely to recover from a perceived skills shortage than higher educated older employees. The interaction terms for level of education in our models (3 - promotion) and (4 - demotion) are not significant. Logistic regression models (2), (3) and (4) in Table 7.4 are all statistically significant and explain between 9 and 11\% of the variance (Nagelkerke $R^{2}$ ) in skills shortage recovery probability.

On Hypothesis 3, column (1) in Table 7.5 shows a significant negative relationship $(\operatorname{Exp}(B)=$ $0.62 ; p<.01$ ) of work redesign on skills shortage recovery. Older employees who take part in one or more of the three work redesign activities are less likely to recover from a perceived skills shortage than older employees who do not take part in these activities. The interaction term for level of education (work redesign activity * less educated) is not significant. This shows that less educated older employees who take part in work redesign activities are just as likely to recover from perceived skills shortage as higher educated older employees who take part in work redesign activities. The logistic regression model for work redesign activities in general (1) is statistically significant $\left(\chi^{2}=97.82 ; p<.01\right)$, but explains $11 \%\left(\right.$ Nagelkerke $\left.R^{2}\right)$ of the variance in skills shortage recovery probability. 
Next, we examine the effects of the three specific work redesign activities. We find strong negative effects of getting fewer tasks $(\operatorname{Exp}(B)=0.56 ; p<.01)$, and smaller but also significant negative effects of getting more tasks $(\operatorname{Exp}(B)=0.77 ; p<.10)$ and getting different tasks $(\operatorname{Exp}(B)$ $=0.70 ; p<.05$ ) on skills shortage recovery probabilities (Table 7.4, columns (2), (3) and (4)). Older employees who have their work redesigned in terms of getting fewer, more or different tasks, are all less likely to recover from a perceived skills shortage than older employees who did not have their work redesigned. Interaction terms for level of education (WR1 * less educated, etc.) in our respective models are not significant. This suggests that the effects for the three work redesign activities are not different for less educated older employees compared to higher educated older employees. Logistic regression models (2), (3) and (4) in Table 7.5 are all statistically significant and explain between 10 and $11 \%$ of the variance (Nagelkerke $R^{2}$ ) in skills shortage recovery probability.

Finally, Tables 7.3, 7.4 and 7.5, show that less educated and male older employees are significantly more likely to recover a perceived skills shortage than higher educated and female older employees. Also, older employees in (highly) unstable organisations are generally less likely to recover from a perceived skills shortage than older employees in more stable organisations and older employees in the construction, finance or health sector or in small companies, are more likely to recover than older employees in the industry sector or in large companies (250+). 
Table 7.3 Logistic regression estimation results on recovery from skills shortage through development (DEV) activities

\begin{tabular}{|c|c|c|c|c|}
\hline & 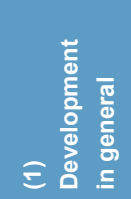 & 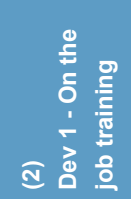 & 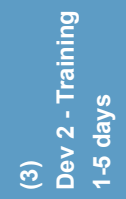 & 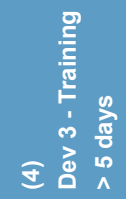 \\
\hline Demographic variables & Odds ratio & Odds ratio & Odds ratio & Odds ratio \\
\hline Constant & 1.02 & 1.50 & 1.24 & 0.88 \\
\hline Lower education $($ ISCED < 3) (ref =higher educated) & $1.50^{* * *}$ & $1.49^{* *}$ & $1.51^{* * *}$ & $1.50^{* * *}$ \\
\hline Age $($ ref $=55-64)$ & 1.23 & 1.21 & 1.23 & $1.26^{*}$ \\
\hline Gender (ref = female) & $1.40^{* *}$ & $1.39^{* *}$ & $1.43^{* *}$ & $1.39 * *$ \\
\hline Permanent contract (ref = other) & 0.90 & 0.91 & 0.90 & 0.93 \\
\hline \multicolumn{5}{|l|}{ Organizational stability (ref = Stable) } \\
\hline - Slightly unstable organization & 0.83 & 0.83 & 0.82 & 0.81 \\
\hline - Unstable organization & $0.66^{* *}$ & $0.66^{* *}$ & $0.65^{* *}$ & $0.65^{\star *}$ \\
\hline - Highly unstable organization & $0.33^{* * *}$ & $0.33^{* * *}$ & $0.33^{* * *}$ & $0.32^{* * *}$ \\
\hline \multicolumn{5}{|l|}{ Sector of industry (ref = Industry) } \\
\hline - Agriculture & 0.81 & 0.74 & 0.73 & 0.79 \\
\hline - Construction & $2.83^{* * *}$ & $2.83^{* * *}$ & $2.78^{\star * *}$ & $2.96^{* * *}$ \\
\hline - Trade & 0.95 & 0.96 & 0.95 & 0.99 \\
\hline - Transportation & 1.38 & 1.40 & 1.41 & 1.45 \\
\hline - Hotels restaurants and bars & 0.70 & 0.68 & 0.70 & 0.68 \\
\hline - ICT & 0.60 & 0.61 & 0.59 & 0.64 \\
\hline - Finance & $2.41^{* *}$ & $2.51^{* *}$ & $2.47^{* *}$ & $2.57^{* * *}$ \\
\hline - Business & 1.15 & 1.17 & 1.15 & 1.21 \\
\hline - Government & 1.21 & 1.26 & 1.21 & 1.22 \\
\hline - Education & 0.81 & 0.85 & 0.83 & 0.85 \\
\hline - Health & $1.55^{*}$ & $1.62^{* *}$ & $1.58^{*}$ & $1.68^{* *}$ \\
\hline - Culture & 0.70 & 0.72 & 0.71 & 0.74 \\
\hline \multicolumn{5}{|l|}{ Company size (ref = Small 1-49 employees) } \\
\hline - Medium (50-249 employees) & 0.85 & 0.86 & 0.87 & 0.86 \\
\hline - Large (250 employees or over) & $0.72^{*}$ & $0.74^{*}$ & $0.74^{*}$ & $0.74^{*}$ \\
\hline Development (Dev1, Dev2 and/or Dev3) & $1.37^{*}$ & & & \\
\hline Instruction and/or training on the job (Dev1) & & 1.09 & & \\
\hline Training $1-5$ days $($ ref $=$ no $)(\operatorname{Dev} 2)$ & & & $1.29^{*}$ & \\
\hline Training $>5$ days $($ ref $=$ no $)(\operatorname{Dev} 3)$ & & & & $1.79^{* * *}$ \\
\hline Interactions (Dev1,2 and/or $3^{*}$ Less educated) & 0.82 & & & \\
\hline Dev1*Less educated & & 1.01 & & \\
\hline Dev2*Less educated & & & 0.90 & \\
\hline Dev3*Less educated & & & & 0.95 \\
\hline \multicolumn{5}{|l|}{ Model fit } \\
\hline$\chi^{2}$ & $89.09^{* * *}$ & $85.62^{* * *}$ & $89.13^{* * *}$ & $94.21^{* * *}$ \\
\hline Full model Nagelkerke $R^{2}$ & .10 & .09 & .10 & .10 \\
\hline $\mathrm{N}$ & 1,281 & 1,281 & 1,281 & 1,281 \\
\hline
\end{tabular}

${ }^{*} p<.10,{ }^{* *} p<.05,{ }^{* * *} p<.01$ 
Table 7.4 Logistic regression estimation results on recovery from skills shortage through mobility (Mob) activities

\begin{tabular}{|c|c|c|c|c|}
\hline & 를 & 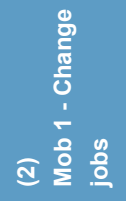 & लํํㅇ 흘 & 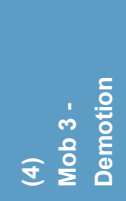 \\
\hline Step 1: Demographic variables & Odds ratio & Odds ratio & Odds ratio & Odds ratio \\
\hline Constant & 1.87 & 1.90 & 1.55 & $4.33^{*}$ \\
\hline Lower education (ISCED < 3) (ref =higher educated) & $1.53^{* * *}$ & $1.43^{* *}$ & $1.48^{* *}$ & $1.47^{* *}$ \\
\hline Age $($ ref $=55-64)$ & 1.21 & 1.17 & 1.21 & $1.33^{* *}$ \\
\hline Gender (ref = female) & $1.33^{* *}$ & $1.35^{\star *}$ & $1.38^{* *}$ & $1.37^{* *}$ \\
\hline Permanent contract (ref = other) & 1.01 & 1.06 & 0.94 & 0.89 \\
\hline \multicolumn{5}{|l|}{ Organizational stability (ref = Stable) } \\
\hline - Slightly unstable organization & 0.80 & 0.76 & 0.84 & 0.88 \\
\hline - Unstable organization & $0.70^{* *}$ & $0.69^{* *}$ & $0.66^{* *}$ & $0.68^{* *}$ \\
\hline - Highly unstable organization & $0.32^{* * *}$ & $0.30^{* * *}$ & $0.33^{* * *}$ & $0.34^{* * *}$ \\
\hline \multicolumn{5}{|l|}{ Sector of industry (ref = Industry) } \\
\hline - Agriculture & 0.81 & 0.80 & 0.74 & 0.65 \\
\hline - Construction & $2.88^{* * *}$ & $2.87^{* * *}$ & $2.83^{* * *}$ & $2.93^{* * *}$ \\
\hline - Trade & 1.12 & 1.00 & 0.98 & 0.97 \\
\hline - Transportation & 1.38 & 1.35 & 1.40 & 1.23 \\
\hline - Hotels restaurants and bars & 0.66 & 0.64 & 0.68 & 0.69 \\
\hline - ICT & 0.64 & 0.63 & 0.61 & 0.60 \\
\hline - Finance & $2.37^{* * *}$ & $2.15^{* *}$ & $2.54^{\star * *}$ & $2.27^{* *}$ \\
\hline - Business & 1.34 & 1.22 & 1.17 & 1.19 \\
\hline - Government & 1.39 & 1.34 & 1.29 & 1.28 \\
\hline - Education & 0.89 & 0.86 & 0.88 & 0.79 \\
\hline - Health & $1.76^{* *}$ & $1.67^{* *}$ & $1.63^{* *}$ & $1.56^{*}$ \\
\hline - Culture & 0.87 & 0.80 & 0.72 & 0.67 \\
\hline \multicolumn{5}{|l|}{ Company size (ref = Small 1-49 employees) } \\
\hline - Medium (50-249 employees) & 0.92 & 0.93 & 0.87 & 0.81 \\
\hline - Large (250 employees or over) & 0.84 & 0.87 & $0.75^{*}$ & $0.73^{*}$ \\
\hline Mobility(Mob1, Mob2 and/or Mob3) & $0.73^{\star *}$ & & & \\
\hline Change of job/function (ref = no) (Mob1) & & 0.79 & & \\
\hline Promotion (ref = no) $($ Mob2) & & & 1.04 & \\
\hline Demotion (ref = no) (Mob3) & & & & $0.36^{* * *}$ \\
\hline Interactions (Mob*Loweduc) & 0.75 & & & \\
\hline Mob1*Less educated & & $0.34^{\star *}$ & & \\
\hline Mob2*Less educated & & & 1.02 & \\
\hline Mob3*Less educated & & & & 1.25 \\
\hline \multicolumn{5}{|l|}{ Model fit } \\
\hline$\chi^{2}$ & $85.23^{* * *}$ & $82.31^{* * *}$ & $84.52^{\star \star *}$ & $97.12^{* \star *}$ \\
\hline Full model Nagelkerke $R^{2}$ & .10 & .10 & .09 & .11 \\
\hline N & 1,213 & 1,185 & 1,277 & 1,175 \\
\hline
\end{tabular}

${ }^{*} p<.10,{ }^{* *} p<.05,{ }^{* * *} p<.01$ 
Table 7.5 Logistic regression estimation results on recovery from skills shortage through work redesign (WR) activities

\begin{tabular}{|c|c|c|c|c|}
\hline & 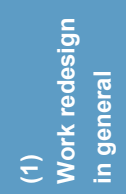 & ล & 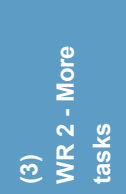 & 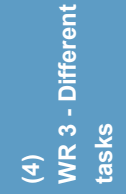 \\
\hline Step 1: Demographic variables & Odds ratio & Odds ratio & Odds ratio & Odds ratio \\
\hline Constant & 2.62 & 3.03 & 2.44 & 2.48 \\
\hline Lower education $($ ISCED < 3) (ref =higher educated) & $1.46^{* *}$ & $1.46^{* *}$ & $1.46^{* *}$ & $1.44^{* *}$ \\
\hline Age $($ ref $=55-64)$ & 1.14 & $1.25^{*}$ & 1.15 & 1.18 \\
\hline Gender (ref $=$ female) & $1.44^{* *}$ & $1.40^{* *}$ & $1.39 * *$ & $1.38^{* *}$ \\
\hline Permanent contract (ref $=$ other) & 0.98 & 0.91 & 0.92 & 0.91 \\
\hline \multicolumn{5}{|l|}{ Organizational stability (ref = Stable) } \\
\hline - Slightly unstable organization & 0.83 & 0.82 & 0.84 & 0.84 \\
\hline - Unstable organization & $0.74^{*}$ & $0.68^{* *}$ & $0.67^{* *}$ & $0.69^{* *}$ \\
\hline - Highly unstable organization & $0.38^{\star * *}$ & $0.34^{\star \star *}$ & $0.35^{\star * *}$ & $0.36^{* * *}$ \\
\hline \multicolumn{5}{|l|}{ Sector of industry (ref = Industry) } \\
\hline - Agriculture & 0.58 & 0.69 & 0.67 & 0.68 \\
\hline - Construction & $2.56^{* *}$ & $2.91^{* * *}$ & $2.67^{* * *}$ & $2.71^{* * *}$ \\
\hline - Trade & 0.89 & 0.96 & 0.93 & 0.97 \\
\hline - Transportation & 1.39 & 1.47 & 1.33 & 1.38 \\
\hline - Hotels restaurants and bars & 0.70 & 0.67 & 0.64 & 0.63 \\
\hline$\cdot \mathrm{ICT}$ & 0.59 & 0.60 & 0.58 & 0.60 \\
\hline - Finance & $2.58^{* * *}$ & $2.47^{* *}$ & $2.48^{* *}$ & $2.51^{* *}$ \\
\hline - Business & 1.21 & 1.18 & 1.13 & 1.15 \\
\hline - Government & 1.26 & 1.30 & 1.23 & 1.29 \\
\hline - Education & 0.89 & 0.86 & 0.85 & 0.88 \\
\hline - Health & $1.67^{* *}$ & $1.66^{\star *}$ & $1.60^{*}$ & $1.66^{* *}$ \\
\hline - Culture & 0.61 & 0.73 & 0.70 & 0.71 \\
\hline \multicolumn{5}{|l|}{ Company size (ref = Small 1-49 employees) } \\
\hline - Medium (50-249 employees) & 0.85 & 0.87 & 0.87 & 0.87 \\
\hline - Large (250 employees or over) & $0.74^{*}$ & $0.75^{*}$ & 0.77 & $0.75^{*}$ \\
\hline Step 2: Work Redesign (WR1, WR2 and/or WR3) & $0.62^{\star * *}$ & & & \\
\hline Fewer tasks $($ ref $=$ no) $($ WR1 $)$ & & $0.56^{* * *}$ & & \\
\hline More tasks $($ ref $=$ no) $($ WR2) & & & $0.77^{*}$ & \\
\hline Different tasks $($ ref $=$ no) $($ WR3 $)$ & & & & $0.70^{* *}$ \\
\hline Step 3: Interactions (WR*Less educated) & 0.92 & & & \\
\hline WR1*Less educated & & 1.60 & & \\
\hline WR2*Less educated & & & 0.74 & \\
\hline WR3*Less educated & & & & 0.81 \\
\hline \multicolumn{5}{|l|}{ Model fit } \\
\hline$\chi^{2}$ & $97.82^{* * *}$ & $94.85^{* * *}$ & $89.66^{* * *}$ & $92.10^{* * *}$ \\
\hline Full model Nagelkerke $R^{2}$ & .11 & .10 & .10 & .10 \\
\hline $\mathrm{N}$ & 1,256 & 1,281 & 1,281 & 1,281 \\
\hline
\end{tabular}

${ }^{*} p<.10,{ }^{* *} p<.05,{ }^{* * *} p<.01$ 


\subsection{Conclusions}

In this study we tested the hypotheses that less educated older employees who 'take the development, mobility or work redesign route' are more likely to recover from a perceived skills shortage than less educated older employees who do not. We distinguish between nine different activities. For development we analysed whether employees received instructions or training on the job, took part in 1-5 days of training or took part in more than 5 days of training. For mobility we analysed whether employees changed jobs, got promoted or got demoted. And for work redesign we analysed whether employees got fewer tasks, more tasks or different tasks. The main question is 'Does taking part in development, mobility and/or work redesign activities help less educated older employees to recover from a perceived skills shortage?'.

We do not find the expected positive effect of training or instructions on the job and skills shortage recovery. These results do not differ between low and higher educated older employees. This confirms earlier research by Allen and De Grip (2012) and Borghans, Fouarge and De Grip (2011) who also did not find a direct relationship between training participation and perceived skills obsolescence and employability. Allen and De Grip (2012) suggested that the lack of a direct effect of training participation underpins the suggestion for a more dynamic perspective on the relationships between technological and organisational change, training activities and employability. This dynamic perspective treats perceived skills shortage as a more or less structural feature of contemporary, continuously changing, jobs. Prolonging an achieved state of skills match, in this dynamic perspective, would only be possible by slowing down organisational and technological change, which would be an unrealistic suggestion, however (Allen \& De Grip, 2012). Instructions or training on the job will 'cure' skills shortage only shortly, before ongoing organisational and/or technological change make employees perceive a new skills shortage.

In this study, we do however find that older employees, both less and higher educated, who participated in more substantial off the job training (1-5 days or more than 5 days), are significantly more likely to recover from a perceived skills shortage than older employees who did not participate in these types of training. These findings lead us to suggest that recovering from a skills mismatch is only possible by introducing substantial training spells and off the job training.

With respect to the mobility and work redesign activities we studied, we do not find any empirical support for our hypotheses that taking part in these kinds of activities increases the chances of older employees recovering from a perceived skills shortage. 
On the contrary even. Taking part in most of the mobility and work redesign activities under study appears to decrease rather than increase employees' skill mismatch. For instance, getting demoted (mobility) or getting fewer tasks (work redesign), makes older employees less likely to recover from a perceived skills shortage. We find a possible explanation for these findings in a recent study by Josten and Schalk (2010), who show that demotion and getting fewer tasks actually decrease employee satisfaction with their job content. Adding to this, Vansteenkiste and Verbruggen (2011) find that demoted employees view a demotion as a 'forced transition'. Based on these results, we suggest that the dissatisfaction with the job content after the, probably forced, demotion took place, may have caused employees to stop acquiring the job-specific skills needed for the newly acquired job. Then, mobility and work redesign activities could indeed decrease rather than increase chance of recovering from a perceived skills shortage. Further analyses including interaction effects for (dis)satisfaction with a newly acquired job after demotion, and possibly even demoted employees own views on this demotion or on getting fewer tasks, and the relationship between demotion and skills rematch probabilities are in order. Our STREAM data do not contain this information, however.

Older employees who get more tasks or different tasks also appear to have less chance to recover from a perceived skills shortage. This is also not in line with our suggestion that redesigning work through changing tasks would better suit employees' skills set and help them to recover from a perceived skills shortage. We find a possible explanation for our findings in the literature on skills obsolescence (for a review see Sanders \& Kraan, 2013). This literature states that older employees' skills sets partly become 'obsolete' in the way that some of the skills an employee posses are no longer required for any of the tasks at hand in an organisation or even in the labour market. These 'obsolete' skills can no longer be used productively and lose their value. In other words, there is no way work can be redesigned in such a way that all skills of an employee can be used productively. If there are no tasks suitable for one's skills, getting different or more tasks would automatically imply a need for new skills to fulfil these tasks, and this will increase the perception of skills shortage, rather than decrease it as we suggested. Further research using more data on skills obsolescence may shed more light on these findings.

Another explanation for our finding that getting different tasks increases rather than decreases skills shortage recovery probabilities, comes from Borghans et al. (2009) who show that carrying out new tasks is an important and effective strategy for learning new skills. We suggest that if stimulating informal learning through performing different tasks is a strategic choice, employees who get different tasks will automatically initially be more likely to perceive more rather than less skills shortage. 
We would need more information on the reason why employees get different tasks in order to be able to make a distinction between those who get different tasks in order to build new skills for future tasks and thus first perceive more rather than less skills shortage, and those who get different tasks in order to use currently available skills more productively and thus recover from a perceived skills shortage.

Finally, in this study, we find that older employees in (highly) unstable organizations in terms of 'restructuring' spells, are significantly less likely to recover a perceived skills shortage than those who work in more stable organisations. We find these results in every single model we estimated (ORs vary from 0.30 to 0.38 ). These findings are in accordance with Marsick and Watkins (2001), Neuman and Weiss (1995) and Gould, Moav and Weinberg (2002). Many studies have also shown that skills shortages have detrimental effects on performance, productivity and job security (De Wit, 2005; Allen \& De Grip, 2012; Sanders \& Kraan, 2013) and that technological and organisational changes follow each other in ever quicker succession, causing the half-life of skills to become shorter (Van der Heijden, Gorgievski, \& de Lange, 2016). In a recent study Sanders et al. (2013b) also show that the perception of skills shortage triggers employees to stop seeking new learning experiences rather than start seeking them. Not seeking new learning experiences is related to lower levels of employee productivity, job satisfaction and declining health (Damman, 2014), but also to a further increase in perceived skills shortage (Sanders, Jetten, Dhondt, Geuskens, Keijzer, \& Liebregts 2013b). The latter implies the risk of a downward spiral of motivation and skills mismatch, leaving an employee's fragile employability even more fragile on both the internal and external labour market, eventually causing job loss, either forced (lay-off) or voluntarily (retirement), but probably prematurely.

These findings underpin a growing need for both employees and employers to do everything in their power to prevent skills shortage and to stimulate recovery when skills shortage is perceived. This requires that either employers prevent (the perception of) organisational instability, or, as Allen and De Grip (2012) put it, 'slow down organisational change'. However, since this has become a rather unappealing, maybe even unrealistic, strategy for most companies and businesses, in our rapidly globalizing economy, a (more) realistic approach would be that employers need to learn and facilitate their employees to cope with organisational instability and remain open and ready for change and be 'adaptable' as suggested by Axtell et al. (2002), Poell et al. (2004), Oreg and Van Dam (2009) and Van Dam (2013), whilst safeguarding the balance between employers' and employees' opposing interests in work-life balance (Van der Heijden et al., 2016). 


\subsubsection{Limitations and directions for further research}

When interpreting the findings of this study, some limitations should be kept in mind. First, in our analyses we use self-reported (subjective) measures for perceived skills shortage and recovery and assume employees' perceptions are stable throughout the research period 2010, 2011 and 2012. We are well aware that using self-reported data imply certain biases, specifically in a longitudinal study design. By filling out the same questionnaire annually, it is possible that the responses given in one wave will be influenced by those given in previous waves (Trivellato, 1999). This may affect repeated measurements of perceived skills shortage and therefore our measurement of skills shortage recovery. It remains unclear, however, whether there is a positive or negative bias. We do have reasons to believe that the effect is rather small, since there is a full year between two measurements which gives the respondents enough time to 'forget' their answer on a previous wave. To rule out these biases completely, however, we suggest future studies to include multiple measuring instruments. For instance, a combination of employee and employer, manager and/or co-worker perceptions of skills shortage and recovery, or expert opinions on skills shortage and recovery thereof on multiple points in time.

Furthermore, sustainable employability is not exclusively 'for the old'. It is important to study effective development, mobility and work redesign activities for younger employees in their efforts to develop and use their skills optimally to remain fit for the labour market until their retirement. Our data exclude younger employees (under 45 years). Results of this study are therefore only representative for the group of older employees (45-64 years old). We would suggest follow-up studies on the effectiveness of development, mobility and work redesign activities for younger employees as well.

Third, mobility and work redesign studies should focus more precisely on practices that were actually meant to solve a skills shortage. Different employees in different companies may have become mobile or may have had their work redesigned for very different reasons. Although we control for gender, age, educational attainment and type of contract as well as for organisational stability, sector of industry and company size in order to control for these dynamics, this is not enough to rule out problems with endogeneity in general and unobserved heterogeneity in particular. These problems arise, for instance, because reasons for employees or companies to redesign work or have employees become mobile may very well be correlated with skills shortage perceptions at multiple measuring points. Whether or not an employee takes the initiative to redesign his/her work or become mobile may be correlated with the perception of skills shortage. Data on who took the initiative and what was the goal of certain mobility and work redesign activities are not available, however, and need to be gathered in future. We suggest experiments within companies, for specific jobs and professions and preferably in a way that detailed 
information on what aspects of work are redesigned exactly and by whom. That would enable scholars to better understand work redesign activities and their effectiveness in terms of skills shortage prevention and recovery and would rule out problems with endogeneity and unobserved heterogeneity we meet in this study.

Finally, in this study we look at skills rematch probabilities 2 years after employees stated they perceived a skills shortage. In 2 years many different changes could have taken place, however. For instance, a perceived skills shortage at T1 may very well have been resolved between T1 and T3 but new organisational or technological changes may have caused a new skills shortage to occur. Although we control for organisational dynamics by including organisational stability and sector of employment, we cannot rule out that other changes have taken place that are related to activities on the development, mobility or work redesign route and to employees perceiving skills shortage. We suggest follow-up studies with multiple measurements of perceived skills shortage and actions taken to rematch skills to jobs in order to tackle this problem, for instance using diary studies. 


\section{Conclusions}




\section{Chapter 8: Conclusions and Discussion}

In this final chapter, I summarize the main findings of the studies presented in this thesis and discuss their respective relevance. Chapters 1 and 2 describe a conceptual model which considers 'sustainable employability' as a constant and dynamic (self-)matching process. At any given time, employees perceive a match and/or a mismatch with their job. A perceived (mis)match can refer to a motivation (mis)match and/or a skills (mis)match. In this thesis, I focus on perceived skills shortage. When employees perceive skills shortages they might consider several activities to recover the skills match. In this thesis, I focus on development, mobility and work redesign activities. My central aim was to find out why less educated employees are underrepresented in these HR activities and if participating in these HR activities makes a difference for less educated (older) employees in terms of recovering from perceived skills shortages.

\subsection{Development}

Chapters 3 and 4 report the results from two studies using data from the Study on Life Long Learning and Employment by TNO. This is a three wave longitudinal study among 350 less educated employees in three different companies (energy sector, electronics and sheltered employment) in the Netherlands. The aim of these studies was to show how less educated employees can be stimulated to start participating in training in order to restore a perceived skill shortage or to prevent an expected skills shortage.

\subsubsection{Pre-training self-efficacy and the role of positive learning experience}

On the basis of Ajzen and Fishbein's Theories of Planned Behavior (TPB) and Reasoned Action (TRA) and Bandura's Social Learning Theory, Chapter 3 finds that differences in training participation are largely explained by differences in training intentions and that these training intentions can be fostered by improving employees' general attitude towards training ('Training is a good thing') and pre-training self-efficacy ('I can successfully take part in training').

Chapter 4 shows that positive learning experiences improve less educated employees' pretraining self-efficacy. To participate in training, pre-training self-efficacy appears crucial, and to improve pre-training self-efficacy we show that building positive learning experiences is an effective strategy. Although our sample of employees with actual training experiences is small and does not allow us to draw conclusions on all less educated employees, our results are in line with Bandura's theoretical suggestions in Social Cognitive Theory (Bandura, 1982) and empirical 
findings by, for instance, Illeris (2006). Based on these results for less educated employees, I suggest that management and co-worker support should contribute to increase the quality of the experience less educated employees have with learning and training, so that these experiences are first and foremost positive experiences. Positive training experiences are crucial in stimulating lifelong learning, which is necessary for sustaining employability in the highly dynamic labour market of the $21^{\text {st }}$ century. Positive learning experiences can be reached by setting reachable and possibly personal goals for a training course, not putting too much emphasis on the effectiveness of a training in terms of acquired skills or knowledge and by trying to make training as agreeable as possible in terms of setting, trainer and content (Smit et al., 2005). For instance, for less educated employees informal learning in the workplace may very well be more suitable than training in a classroom setting (Illeris, 2006). Striving for positive training experiences also means stimulating positive knowledge spill-overs between peers in the workplace, sharing positive learning experiences and preventing negative attitudes among co-workers and management (Rainbird, 2000; Geenen et al., 2013). Finally, I suggest pre-training interventions that help less educated employees to deal with stress and fear of exams and that help set realistic training goals, so that employees remain engaged and committed to training.

\subsubsection{Recovering from perceived skills shortages; development activities}

Chapter 7 studies whether taking the development route is actually an effective strategy to recover from skills shortage perceived by less educated older employees. We look at the effects of three different learning activities on the probability that older employees recover from a perceived skills shortage: 1 ) instruction or training on the job, 2) short training for 1-5 days and 3) substantial training for more than 5 days. I do not find that training or instructions on the job have a significant impact on skills shortage recovery. These results confirm earlier research by Allen and De Grip (2012) and Borghans, Fouarge and De Grip (2011), and suggest that skills shortage needs to be considered a more or less structural feature of contemporary, ever changing, jobs. This kind of training could probably only 'cure' a skills shortage for a brief period of time, before ongoing organisational and/or technological changes make employees perceive a new skills shortage. The strong positive relationship between organisational stability and skills rematch probabilities could underpin this suggestion. However, for short (1-5 days) and substantial off the job training (more than 5 days) we do find a significant positive effect on skills rematch probabilities. Based on these findings, I suggest that maintaining the state of skills match is only possible by having older employees take part in more substantial types of training. 


\subsection{Mobility}

Based on Ajzen and Fishbein's Theories of Planned Behavior(TPB) and Reasoned Action (TRA) and Bandura's Social Cognitive Theory (SCT), Chapter 5 shows that strengthening less educated older employees' pre-mobility self-efficacy increases both the intention to become externally mobile as well as actual external mobility behaviour. Less educated older employees, however, tend to have a lower pre-mobility self-efficacy than higher educated employees. We also show that the positive relationships between a worker's pre-mobility self-efficacy, mobility intentions and mobility behaviour do not differ between less educated and higher educated older employees. I therefore suggest that the low level of pre-mobility self-efficacy may very well be responsible for the actual voluntary mobility behaviour of less educated older employees to stay behind. This shows that the encouragement of self-efficacy for successful job-to-job mobility is a first step in realizing more voluntary mobility among less educated older employees. Analogous to what Chapter 4 finds with respect to pre-training self-efficacy and the role of positive learning experience, I expect that the accumulation of small successful mobility experiences could be highly relevant for less educated employees' sustainable employability. Recent studies into the effects of 'multi-jobbing', for instance, show interesting possibilities for a more gradual type of jobto-job mobility. Other interesting interventions are 'job crafting' or 'work redesign' (Dorenbosch et al., 2011a; Van Vuuren \& Dorenbosch, 2011; Tims, 2013). A follow-up question to the study in Chapter 5 would be whether and to what extent these types of smaller voluntary job transitions can contribute to a more dynamic career build-up and sustainable employability.

\subsubsection{Recovering from perceived skills shortage; mobility activities}

Chapter 7 sets out to test whether mobility activities have an effect on the probability employees recover from a perceived skills shortage. Three different mobility activities are tested: job change (internal mobility), promotion and demotion. No empirical support is found for these three activities helping less educated older employees to recover from a perceived skills shortage. Getting demoted even makes employees significantly less likely to recover from a perceived skills shortage. A possible explanation is that, since demoted employees often view demotion as a forced transition, they may become dissatisfied with the content of their newly acquired job. Demotion may thus cause employees to stop investing in building skills that are needed in the new job which could result in new or increasing skills shortages. Further analyses on the relationship between demotion and skills shortage recovery, including data on the level of (dis)satisfaction with newly acquired jobs after demotion and data on demoted employees' own views on this demotion, would probably enable us to gain more insight in the role of demotion as an instrument for sustaining employability. 


\subsection{Work redesign}

Based upon the classic Job Characteristics Model (JCM) and its later expansions, Chapter 6 reports results from a study aimed to answer three related questions:

1. What differences are there in work characteristics between less educated and higher educated older employees?

2. Which work characteristics are actually related to less educated older employees workability and work motivation?

3. What directions for work redesign can be derived from these results.

Data from the Netherlands Working Conditions Cohort Study (NWCCS) are used.

\subsubsection{Less educated older employees' work characteristics}

On the first research question in this chapter, findings are that less educated older employees score lower than higher educated older employees on all four work characteristics dimensions distinguished in the study (contextual, cognitive-informational, task-motivational and social work characteristics). These findings are in line with earlier findings by Parent-Thirion et al. (2005) and Morgeson and Humphrey (2006). From these findings, I conclude that, in principle, all work characteristics under study here might be eligible for redesign.

\subsubsection{Relationships between work characteristics, work ability and work motivation}

To find the most promising directions for work redesign, Chapter 6 examines whether improving the various work characteristics has positive effects on less educated older workers' work ability and/or work motivation. Improving contextual work characteristics, more specifically decreasing the amount of time employees work in uncomfortable positions, shows to improve both work ability and work motivation. Improving cognitive-informational work characteristics (job complexity) has no effect on work ability and only a weak positive effect on work motivation. Improving task-motivational work characteristics (more autonomy and more task variety) and social work characteristics (more social support by colleagues and supervisor, more interaction with customers and less emotional workload) generally have the desirable effects on less educated older employees' work ability and work motivation.

Based on these results, I suggest (re)designing less educated older employee's work in a way that contextual, task-motivational and social work characteristics are improved. We particularly find that redesigning social work characteristics is promising, since increasing co-worker and supervisor support and interaction with customers and decreasing the emotional workload, have significant and desirable effects on most work ability and work motivation aspects we studied.

Moreover, a study into the benefits of social work characteristics in low-skilled jobs by Leana et al. (2009) demonstrates that the extent to which employees jointly craft or redesign their work 
contributes to their job satisfaction, organizational commitment as well as to the quality of their work. Also, combined with findings in Chapter 6, I suggest organizations should involve less educated employees in (re)designing or crafting their own work characteristics to match their needs and aspirations. In addition, Borghans et al. (2009) have demonstrated that human capital is often built through interaction with colleagues and supervisors. An increase in support from colleagues and supervisors might therefore also lead to a higher level of knowledge and skillbuilding on the job, sustaining employability. These relationships, however, need to be studied more closely.

\subsubsection{Recovering from perceived skills shortages; work redesign}

Chapter 7 shows no empirical support for our hypothesis that work redesign activities (getting fewer, more or different tasks) help less educated older employees to recover from a perceived skills shortage. Getting fewer, more or different tasks even decreases, rather than increases less educated older employees' chances of recovering from a perceived skills shortage. For an explanation I follow the line of reasoning when discussing results on demotion in the mobility activities' Section 8.2.1 suggesting further studies into what tasks one gets relieved from and what tasks remain, as well as into how employees perceive and appreciate getting fewer tasks.

Another possible explanation for the findings in Chapter 7 is found in the skills obsolescence literature (see Sanders \& Kraan, 2013 for a review) which states that older employees' skills sets may partly become 'obsolete'. Obsolete skills can no longer be used productively. If there are no more tasks that suit a worker's skills, getting different tasks implies a need for new skills, rather than a way to better use one's available skills, which will increase rather than decrease skills shortage. Future studies into what skills become obsolete and at what rate, as well as into the effects of (perceiving) skills obsolescence on both the employee and the company level are needed to test these assumptions.

A third and final explanation I present is that getting different tasks may be a strategy for informal learning rather than for recovering from a perceived skills shortage. Borghans et al. (2009) have shown that carrying out new tasks (getting more or getting different tasks) can be an important type of informal learning. More information on why employees get more or different tasks is needed in order to study different work redesign activities and their effects. Work redesign activities can be aimed at optimizing the use of currently available skills, but also at acquiring new skills through learning by doing. 


\subsection{Recovering from skills shortage in unstable organisations: a challenge}

I end this conclusion with a brief discussion on the finding in Chapter 7 that higher levels of organizational instability predict a lower recovery probability for less educated older employees. There is vast literature on the detrimental effects of skills shortage on performance, productivity and job security, but in a study on the concept of 'mental retirement', Sanders et al. (2013b) also show that perceiving skills shortage triggers both less and higher educated employees to stop seeking new learning experiences rather than start seeking them. More recently, no longer seeking new learning experiences has been shown to be negatively related to productivity, job satisfaction and health (Damman, 2014). Sanders et al. (2013b) also find a positive relationship of not seeking new learning experience with perceived skills shortage.

These findings combined imply a risk of a downward spiral of motivation and skills shortage, as suggested in the introduction of this thesis, which may be strengthened by organisational instability in terms of constant restructuring. This downward spiral in motivation and qualification will make employability more fragile instead of sustainable on both the internal and external labour market, eventually causing employees to leave the labour market, either forced (lay-offs) or voluntarily (retirement), but probably prematurely. These results suggest a growing need for both employees and their employers to do everything in their power to prevent skills shortage or the perception thereof, to stimulate immediate recovery when skills shortages are perceived and to do this as soon as possible. This thesis makes clear that training, preferably substantial training, is a promising route to take. However, based on the strong negative effects of organisational instability on skills shortage recovery probability, I also suggest making sure that within these (substantial) training courses, attention is also paid to helping employees cope with organisational instability and remain open and ready for change as suggested by Axtell et al. (2002), Poell et al., (2004), Oreg and Van Dam (2009) and Van Dam (2013) whilst safeguarding their individual work-life balance and the balance between employers' and employees' opposing interests (Van der Heijden et al., 2016).

The challenge ahead, however, is to design the substantial training programmes that are 1) effective in helping less educated (older) employees to recover from perceived skills shortage, 2) effective in helping less educated (older) employees to cope with constant change and remain adaptable and 3) a positive learning experience that increases pre-learning self-efficacy and stimulates lifelong learning. 


\section{Valorisation Addendum}




\section{Chapter 9: Valorisation Addendum}

As pointed out in the introduction to this thesis, sustaining employability has become a topical issue in national and EU labour market as well as in company HR policies. Two major developments have triggered this: the $21^{\text {st }}$ century technology based and highly dynamic labour market and the rapidly ageing (working) population putting pressure on social security and pension systems' affordability in Western societies and on the continuity of businesses. This thesis focuses on sustaining less educated (older) employees' employability. Not only are these employees in precarious jobs and with fragile employability, but they also less often participate in HR activities aimed at sustaining employability, such as training or job-to-job mobility. Also, they are at growing risk of being 'crowded out' by employees with an intermediate level of education, whose jobs are gradually disappearing due to automation of specific tasks. Central aim of this thesis is, therefore, to get a better understanding of why less educated (older) employees do not participate in HR activities to sustain their employability and to find ways to stimulate participation in these HR activities so that current and future skills (mis)matches, as well as claims on social security systems can be minimized and postponed as much as possible.

\subsection{General implications}

Generally speaking, findings in this thesis support earlier findings in sustainable employability research. This thesis adds to these findings, however, in two ways. It mainly uses longitudinal panel data and it focuses solely on less educated (older) employees, generating ideas for HR policies aimed at this important target group for sustaining employability. My findings do not imply that there is a need for very different HR approaches to the target group of less educated (older) employees. They rather suggest that existing HR policies should also be applied to less educated (older) employees. This needs to be done, however, with an appropriate pace and with the explicit demand that these HR policies will be positive experiences for less educated (older) employees, rather than negative ones.

Findings in this thesis are highly relevant for HR practitioners. I address implications for HR practice in more detail in section 9.2 of this addendum. Findings are also relevant, however, for national and EU policy makers, who define and develop (inter)national frameworks to encourage employers and employees to sustain employability in general and that of less educated older employees in particular. Last but not least, findings are relevant for individual employees, who have a lot to gain by mainly taking part in evidence based sustainable employability programs. 


\subsection{Implications for HR practice}

\section{Chapter 2: Focus on three routes}

First, theoretically, Chapter 2 explains how skills and motivation mismatches occur and what can be done to prevent or cure these skills and motivation mismatches. Chapter 2 suggests HR practitioners to focus on three main routes in sustaining less educated employees' employability. These three routes are development (changing the employee), mobility (changing the work and the employee) and work redesign (changing the work). Aligning activities along these three routes will help HR practitioners to frame, monitor and study HR practices and their effectiveness.

\section{Chapters 3, 4 and 5: Development and mobility}

On development, Chapter 3 finds that less educated employees participate less in training, and that this is caused by lacking training intentions. The lack of training intentions is caused by a less positive attitude toward training and by weaker pre-training self-efficacy. These findings suggest HR practitioners to focus on developing and maintaining positive attitudes toward development and change in individual workers, teams, departments and throughout the organisation. Also, they should actively seek ways to strengthen less educated employees' pre-training self-efficacy, for instance by stimulating management and co-worker support for those who engage in development activities.

On strengthening less educated employees' pre-training self-efficacy, Chapter 4 finds that gaining positive learning experiences strengthens pre-training self-efficacy so that training intentions and training participation are stimulated. These findings suggest that HR practitioners need to focus on implementing practices that provide less educated (older) employees with a positive experience. Building partly on the findings in Chapter 4 , Chapter 5 shows that less educated older employees are less mobile and that this is also caused by a weaker (pre-mobility) selfefficacy.

Parallel to the findings in Chapter 4, findings in Chapter 5 suggest strengthening pre-mobility selfefficacy by having employees gain positive mobility experiences. This goes especially when less educated (older) employees are up for their first new learning or mobility experience in many years. Although the literature on how to establish positive learning or mobility experiences among less educated (older) employees is scarce, some suggestions can be derived from literature on positive learning experience in general (see box below). 
Box 9.1

1. Make sure there is a clear picture of, and consensus on the skills a worker has acquired.

2. Focus on a good fit between on the one hand the content of a development or mobility activity, and on the other hand the already acquired skills.

3. Present a worker with accurate information about his or her development and mobility opportunities.

4. Focus on finding 'guides' (trainers, coaches, mentors) who are well attuned to a group or an individual.

5. Guides should focus on providing a positive and safe climate for development and mobility activities. This will also stimulate the positive attitude toward these kinds of activities and it will help employees deal with for instance 'exam anxiety'.

6. Guides need to pay attention to the individual worker and provide feedback on commitment rather than on performance standards in development and mobility activities.

7. Guides should try and minimize competition among colleagues.

8. Stimulate supervisory, co-worker and other relevant peer support (friends, parents, children or spouse) in discussing positive (or negative) experiences with development or mobility.

\section{Chapter 6: Implications for HR practice; work redesign}

Chapter 6 explores the third route in sustaining employability, that of work redesign. In Chapter 6 , I show which work characteristics are most eligible for redesign when the aim is to increase less educated older employees' work ability and work motivation. Findings in Chapter 6 suggest HR practitioners to start experimenting with work redesign so that there is more autonomy, task variety, social support by colleagues and supervisors and interaction with customers and less emotional workload. These work redesigns generally would have desirable effects on less educated older employees' work ability and work motivation. Building on these findings and recent literature on collaborative job crafting (Leana et al., 2009), I also suggest HR practitioners to experiment with involving less educated employees in collaborative work redesign to match individual skills, needs and aspirations.

\section{Chapter 7: Implications for HR practice; what route works}

Finally, Chapter 7 studies the impact of a selection of development, mobility and work redesign activities on skills shortage recovery among less educated older employees. The chapter only shows positive effects of off the job training (1 or more days) on skills shortage recovery. On the job instructions (development), job change and promotion (mobility activities) have no effect at all on skills shortage recovery. Chapter 7 even finds that demotion (mobility) and getting fewer, more or different tasks (work redesign) decreases rather than increases the chance of recovering from a skills shortage.

On development, findings in Chapter 7 suggest that getting instructions and on the job training do not lead to skills shortage recovery among less educated older employees. They need training courses (off the job and at least more than 1 day, preferably even more than 5 days) to keep up. Literature, however, also suggests that for less educated older workers training courses should 
have as little resemblance to a classroom as possible, suggesting workplace learning as a suitable way to engage in development activities. Workplace learning may lead to a positive learning experience, but findings in Chapter 7 suggest that this will not be enough to recover from a perceived skills shortage. My findings also suggests that HR practitioners should look for, and experiment with, other settings than the workplace or the classroom for both learning experiences that are positive as well as sufficiently effective. Suggestions for promising new learning settings are simulators, augmented reality, massive open online courses and serious gaming.

On mobility and work redesign, findings in Chapter 7 imply that the activities on these routes I studied are not effective for better matching less educated older employees' skills sets to the jobs and tasks at hand, and in that sense they do not help employees to recover from a perceived skills shortage. The findings do suggest, however, that mobility and work redesign activities might be effective for stimulating less educated older employees to learn new skills and could via this route contribute to their employability. To conclude, findings in Chapter 7 on both the dynamic process of change, perceived skills shortage and actively restoring the match between the skills of employees and the skills demanded in their jobs, underpin the importance of at least two steps for HR practitioners to be taken:

1. Monitor levels of perceived skills shortage within your company and try to help employees to recover from these as fast and appropriately as possible through substantial training or, if at all possible, through slowing down the speed of organisational change in order to keep as many employees on board as possible;

2. Monitor and maintain the motivation of employees to invest in their sustainable employability, either through training, mobility and work redesign by proper evaluation of the quality of specific HR practices in terms of satisfaction and effectiveness.

\section{3}

\section{Dissemination of the findings}

The findings of this thesis have been presented and discussed during national and international scientific conferences, such as several EAWOP Conferences and small group meetings, an $\mathrm{ICOH}-W O P S$ conference and bi-annual Dutch HRM Conferences. Findings were also presented and discussed at Dutch HR practitioners conferences, such as the annual Dutch P\&O Actueel 2013 conference in Houten. Findings in Chapters 3, 4, 5 and 6 have also been extensively presented and discussed with EU (DG Employment committee) and national policymakers (Ministry of Social Affairs). Findings were also used by TNO staff in developing several intervention programs such as 'Staymobil' and 'Taken van de Toekomst (TvdT)' (Tomorrow's Tasks). 


\section{TNO Staymobil program}

Staymobil is a cooperative intervention building and testing program aimed at sustaining employability. Based on the findings of this thesis, the approach explicitly gives employees a say in which interventions should be implemented and in the content of such interventions, whether they are aimed at development, mobility or work redesign. Since 2014, the Staymobil program is tested in several Dutch companies (Philips, Police, Sociale Verzekeringsbank, Ministry of Internal Affairs). Staymobil starts with a group mind map to decide what sustainable employability actually is for employees and managers and to see what organisational and personal factors stimulate sustainable employability and what factors do not. Next, sustainable employability is measured and determinants and effects are analysed. Based on the results of these analyses in two socalled 'intervention mapping sessions' employees and managers decide which intervention(s) should be implemented in order to strengthen sustainable employability in their organization. These interventions are then implemented in an experimental group, and not in the control group, so that in the final step effects of the intervention that was implemented can be measured. Articles on the successful implementation of Staymobil at Sociale Verzekeringsbank were published in two Dutch HR magazines: PW de Gids (Sanders \& Keijzer, 2015a) and OR Informatie (Sanders \& Keijzer, 2015b).

\section{TNO Taken van de Toekomst (TvdT) (Tomorrow's Tasks)}

Taken van de Toekomst (TvdT) is a digitally supported action approach that aims to help employees and managers to establish current and future tasks, and whether these tasks will grow in importance or not. Next, using a tailor-made online Job Analysis tool a company analyses to what extent its current staff feels skilled and motivated to perform both today's and tomorrow's tasks. Employees and management will thus gain a clear picture of the skills and motivation currently available for the tasks at hand. Moreover, they get an idea of whether these skills and motivation match future tasks, showing current and future skills and motivation mismatches on a task level. Based on the company analysis, advice is given on which development, mobility or work redesign activities should be implemented in order to sustain employability on the individual worker and company level. TvdT has been developed so that it helps HR practitioners come up with interventions that meet the requirements for 'positive experiences', as derived from Chapters 3,4 and 5 in this thesis (see also Box 9.1). For instance, TvdT gives a clear picture of already acquired skills and helps fit development and mobility activities to these already acquired skills. Also, TvdT helps to give accurate information about realistic internal development and mobility opportunities and gives (some) employees a say in defining future tasks. Experiments with 'Taken van de Toekomst' are currently taking place at two Dutch organisations in the public sector to test whether this intervention is effective in sustaining employees' employability. 


\section{References}




\section{References}

Acemoglu, D., \& Autor, D. (2011). Skills, tasks and technologies: Implications for employment and earnings. Handbook of labor economics, 4, 1043-1171.

Ajzen, I. (1985). From intentions to actions: a theory of planned behaviour. In J. Kuhl, \& J. Beckmann (Eds.), Action-control: From Cognition to Behaviour (pp. 11-39). Heidelberg: Springer.

Ajzen, I. (1988). Attitudes, Personality and Behaviour. Milton Keynes: Open University Press.

Ajzen,I. (1991). The theory of planned behaviour. Organizational Behaviour and Human Decision Processes, 50, 179-211.

Akçomak, I.S., Borghans, L., \& Ter Weel, B. (2011). Measuring and interpreting trends in the division of labour in the Netherlands. De Economist, 159(4), 435-482.

Armstrong-Stassen, M., \& Schlosser, F. K. (2008). Benefits of a Supportive Development Climate for Older Workers. Journal of Managerial Psychology, Special Issue on Work and Well Being of Older Workers 23, pp. 419-437.

Armstrong-Stassen, M. (2008). Organisational practices and the post-retirement employment experience of older workers. Human Resource Management Journal, 18, 36-53.

Armstrong-Stassen, M., \& Ursel, N. D. (2009). Perceived organizational support, career satisfaction and the retention of older workers. Journal of Occupational and Organizational Psychology, 82, 201-220.

Allen, J. \& de Grip A. (2012). Does skill obsolescence increase the risk of employment loss? Applied Economics, 44 (25), 3237-3245.

Allen, J. \& van der Velden, R. (2002). When Do Skills Become Obsolete, and When Does It Matter?, In A. de Grip, J. van Loo \& K. Mayhew (Eds.), The Economics of Skills Obsolescence: Theoretical Innovations and Empirical Applications, Research in Labor Economics Volume 21 (pp. 27-50). Oxford: Elsevier Science Ltd.

Amuedo-Dorantes, C., \& Kimmel, J. (2005). Moonlighting behaviour over the business cycle. IZA Discussion Paper, No. 1671.

Arthur, W.A., Bennett, W., Edens, P.S., \& Bell, S.T. (2003). Effectiveness of Training in Organizations: A Meta-Analysis of Design and Evaluation Features. Journal of Applied Psychology, 88, 234-245.

Autor, D., Levy, F., \& Murnane, R. (2003). The skill-content of recent technological change: An empirical investigation. Quarterly Journal of Economics, 118, 1279-1333.

Axtell, C., Wall, T., Stride, C., Pepper, K., Clegg, C., Gardner, P., \& Bolden, R. (2002). Familiarity breeds content: The impact of exposure to change on employee openness and well-being. Journal of Occupational and Organisational Psychology, 75, 217-231. 
Baltes, M. M., \& Carstensen, L. L. (1999). Social-psychological theories and their applications to aging: From individual to collective. In V.L. Bengtson, J-E. Ruth \& K.W. Schaie (Eds.), Handbook of theories of aging (pp. 209-226). New York: Springer.

Bandura, A. (1977). Self-efficacy. Toward a unifying theory of behavioural change. Psychological Review, 84, 191-215.

Bandura, A. (1982). Self-efficacy mechanism in human agency. American Psychologist, 37, 122147.

Bandura, A. (1989). Human agency in social cognitive theory. American Psychologist, 44, 11751184.

Bandura, A. (2001). Social cognitive theory: An agentive perspective. Annual Review of Psychology, 52, 1-26.

Bartel, A.P., \& Sicherman, N. (1993). Technological Change and the Careers of Older Workers. NBER Working Papers Nr. 3433, National Bureau of Economic Research.

Bassanini, A., Booth, A., Brunello, G., de Paola, M., \& Leuven, E. (2005). Workplace Training in Europe. IZA Discussion Paper 1640. Bonn: IZA.

Bateman, T.S., \& Crant, J.M. (1993). The proactive component of organizational behaviour: A measure and correlates. Journal of Organizational Behavior, 14, 103-118.

Bell, D.N.F., Hart, R.A., \& Wright, R.E. (1997). Multiple job holding as a hedge against unemployment. CEPR discussion paper series, No. 1626.

Bierings, H., \& Smits, W. (2008). Mensen met een slechte gezondheid hebben meer moeite om rond te komen. CBS Webmagazine, 8 september 2008.

Blokhuis, F.T.L. (2006). Evidence-based design of workplace learning. Enschede: University of Twente.

Boheim, R., \& Taylor, M.P. (2004). And in the evening she's a singer with the band-second jobs, plight or pleasure. IZA Discussion Paper, No. 1081. Bonn: IZA.

Borghans, L., Golsteyn, B., \& de Grip, A. (2006). Meer werken is meer leren: determinanten van kennisontwikkeling (Working more is learning more, determinants for knowledge development). 's-Hertogenbosch: CINOP.

Borghans, L., Duckworth, Heckman \& Ter Weel (2008). The Economics and Psychology of Personality Traits, NBER Working Papers No 13810, National Bureau of Economic Research, Inc.

Borghans, L., Golsteyn, B., de Grip, A., \& Nelen, A. (2009). Leren op het werk: ontwikkelingen en consequenties voor productiviteit en mobiliteit (Workplace learning: developments and consequences for productivity and mobility).'s-Hertogenbosch: CINOP.

Borghans, L., Ter Weel, B., \& Weinberg, B. A. (2014). People skills and the labor-market outcomes of underrepresented groups. Industrial \& Labor Relations Review, 67(2), 287 334. 
Borghans, L., Fouarge, D., de Grip, A. \& van Thor, J.A.F. (2014). Werken en leren in Nederland (Working and learning in the Netherlands). ROA Reports 003. Maastricht: Research Centre for Education and the Labour Market.

Brehm, J.W. (1972). Responses to loss of freedom: A theory of psychological reactance. New York: General Learning Press.

Bresnahan, T. F., Brynjolfsson, E., \& Hitt, L. M. (1999). Information technology, workplace organization and the demand for skilled labor: Firm-level evidence (No. w7136). National Bureau of Economic Research.

Bresnahan, T. F., Brynjolfsson, E., \& Hitt, L. M. (2002). Technology, Organization, and the Demand for Skilled Labor. The new relationship: Human capital in the American corporation, 145.

Brouwer, S., de Lange, A., van der Mei, S., Wessels, M., Koolhaas, W., Bültmann, U., van der Heijden, B., \& van der Klink, J. (2012). Duurzame inzetbaarheid van de oudere werknemer: stand van zaken. Groningen: Universitair Medisch Centrum Groningen/ Rijksuniversiteit Groningen.

Brown, K.G. (2005). An examination of the Structure and Nomological Network of Trainee Reactions: A Closer Look at "Smile Sheets". Journal of Applied Psychology, 90, 991-1001

Brynjolfsson, E. \& McAfee, A. (2014). The Second Machine Age: Work Progress, and Prosperity in a Time of Brilliant Technologies. New York: W. W. Norton \& Company.

Burdorf A., \& Mackenbach P.J. (2006). De invloed van gezondheid op vervroegde uittreding uit het arbeidsproces. (The influence of health on early retirement). Zoetermeer: Raad voor de Volksgezondheid en Zorg.

Campion, M. A., Mumford, T. V., Morgeson, F. P., \& Nahrgang, J. D. (2005). Work redesign: Obstacles and opportunities. Human Resource Management, 44, 367-390.

Caroli, E., \& Van Reenen, J. (2001). Skill-biased organizational change? Evidence from a panel of British and French establishments. Quarterly journal of economics, 1449-1492.

Cartsensen L.L. (1995). Evidence for a life span theory of socio-emotional selectivity. Current directions in Psychology science, 4, 151-156.

Collquitt, J.A., LePine, J.A., \& Noe, R.A. (2000). Toward an Integrative Theory of Training Motivation: A Meta-Analytic Path Analysis of 20 Years of Research, Journal of Applied Psychology, 85, 678-707.

Commission of the European Communities (2009). Progress towards the Lisbon objectives in education and training. Indicators and benchmarks. Available at: http://ec.europa.eu/education/lifelong-learning-policy/doc/report09/report_en.pdf (accessed 5 july 2013).

Creemers, B.P.M. (1991). Effectieve instructive: Een empirische bijdrage aan de verbetering van het onderwijs in de klas. Den Haag: S.V.O. 
Damen, M., Sanders, J., \& van Dam, K. (2013). Leve lang leren: Het effect van een positieve leerervaring op de self-efficacy van laagopgeleiden. (Long live long learning: the effect of a positive learning experience on less educated workers self-efficacy). Tijdschrift voor Arbeidsvraagstukken, 29, 376-390.

Daniel, K., \& Heywood, J. (2007). The determinants of hiring older workers: UK evidence. Labour Economics, 14, 35-51.

Davis, L.E., Ajzen, I., Saunders, J., \& Williams, T. (2002). The decision of African American students to complete high school: An application of the theory of planned behavior. Journal of Educational Psychology, 94, 810-819.

De Beer, P.T. (2006). Perspectieven voor de laagopgeleiden (Perspectives for less educated workers). Tijdschrift voor Arbeidsvraagstukken, 22, 218-233.

De Graaf-Zijl, M. (2012). Job satisfaction and contingent employment. De Economist, 160(2), 197-218.

De Grip, A., \& Van Loo, J. (2002). The economics of skills obsolescence: a review. in: De Grip, A., van Loo, J., \& Mayhew, K. The Economics of Skills Obsolescence. Research in Labour Economics, vol. 21, JAI Press, 1-26.

De Grip, A., van Loo, J., \& Sanders, J. (2004). The industry employability index: Taking account of supply and demand characteristics. International Labour Review, 143(3), 211-233.

De Grip, A. (2006). Evaluating Human Capital Obsolescence. ROA-W-2006/2E, ROA, Maastricht.

De Sitter, L.U. (1994). Synergetisch produceren. Human Resources Mobilisation in de produktie: een inleiding in structuurbouw (Synergetic production. Human Resources Mobilization in production: an introduction to structure building). Assen: Van Gorcum.

De Vries R., Wolbers, M., \& van der Velden, R. (2004). De arbeidsmarktpositie van schoolverlaters en werkenden zonder startkwalificatie (The labour market position of school leavers and working people with no basic qualification). The Hague: RWI.

Deci, E.L., \& Ryan, R.M. (2000). The "what" and "why" of goal pursuits: Human needs and the self-determination of behavior. Psychological Inquiry, 11, 227-268.

Descy, P. (2006). Review of European and international statistics. In T. Tikkanen, \& B. Nyhan (Eds.), Promoting lifelong learning for older workers: an international overview. Luxembourg: Publications Office.

Dickey, H., Watson, V., \& Zangelidis, A. (2009). What triggers multiple job holding? An experimental investigation. MPRA Paper, No. 17575. http://mpra.ub.unimuechen. de/17575/.

Doets, C., van Esch, W., \& Westerhuis, A. (2008). Een brede verkenning van een leven lang leren. 's-Hertogenbosch: Cinop. 
Dorenbosch, L., \& Sanders, J. (2010). Gedeeld werkgeverschap naar Frans voorbeeld: veelbelovend van-werk-naar-werk instrument voor het midden- en kleinbedrijf? (Joint employment practice according to the French model: a promising job-to-job instrument for small and medium-sized enterprises?) Over.Werk, 2, 44-49.

Dorenbosch, L., Gründemann, R., \& Sanders, J. (2011a). Sleutelen aan eigen inzetbaarheid: kansen en keerzijdes van job crafting als methodiek ter bevordering van duurzame inzetbaarheid in de context van lageropgeleid werk (Working on one's own employability: the pros and cons of job crafting as a methodology for promoting sustainable employability in the context of lower-skilled work). Hoofddorp: TNO.

Dorenbosch, L., Huiskamp, R., \& Smulders, P. (2011b). De relatie tussen baanontevredenheid en vetrekintenties: maakt opleiding een verschil? (The relationship between job dissatisfaction and intentions to leave: does training make a difference?) Tijdschrift voor arbeidsvraagstukken, 27, 77-93.

Dorenbosch, L., Boneschansker, O., Sanders, J., \& Koppes, L. (2013). Redenen voor het combineren van meerdere banen (Reasons for combining multiple jobs). Economisch Statistische Berichten (ESB), 4666, 480-482

Dorenbosch, L. (2014). HRM toepassingen van een digitale job crafting applicatie. In Handboek voor HRM (Vakmedia) (The use of a digital job crafting application for HR professionals).

Dorenbosch, L., Sanders, J., \& Beudeker, D. (2015). Multi-jobbing: wenselijk of onwenselijke arbeidsmarktdynamiek? In K. Chkalova, A. Goudswaard, J. Sanders \& W. Smits (Eds.), Dynamiek op de Nederlandse arbeidsmarkt, de focus op flexibilisering (Dynamics in the Dutch labour market, focus on flexibility) (pp. 170-196). The Hague/Heerlen: CBS.

Doty, D.H., \& Glick, W.H. (1998). Common methods bias: Does common methods variance really bias results? Organizational Research Methods, 1, 374-406.

Dychtwald, K., Erickson, T.J., \& Morison, R. (2006). Workforce Crisis: How to Beat the Coming Shortage of Skills and Talent. Boston (MA): Harvard Business School Press.

Edwards, J. R., Scully, J. A., \& Brtek, M. D. (2000). The nature and outcomes of work: A replication and extension of interdisciplinary work-design research. Journal of Applied Psychology, 85, 860-868.

Ellis, R.A., \& Taylor, M.S. (1983). Role of self-esteem within the job search process. Journal of Applied Psychology, 68, 632-640.

Elsbach, K.D., \& Hargadon, A.B. (2006). Enhancing creativity through "mindless" work: A framework of workday design. Organization Science, 17, 470-483.

Ester, P. \& Kerkhofs, M. (2009). Human capital and the older worker, the need for solid indicators. Available at: http://www.oecd.org/dataoecd/31/40/38756264.pdf (accessed 18 March 2015). 
European Commission (2005). Confronting demographic change: A new solidarity between the generations. Brussels: European Commission.

European Commission (DG ECFIN) and Economic Policy Committee (AWG) (2008). The 2009 Ageing Report: Underlying Assumptions and Projection Methodologies for the EU-27 Member States (2007-2060). Luxembourg: Office for Official Publications of the European Communities.

European Foundation for the Improvement of Living and Working Conditions (Eurofound) (2008). Working conditions of an ageing workforce. Luxembourg: Office for Official Publications of the European Communities.

European Union (2010). New skills for new jobs: Action now. A report by the expert group on new skills for new jobs prepared for the European commission. Brussels: European Union.

Eurostat (2004). Community Innovation Survey, Questionnaire. Retrieved 28.01.2011, from: http://www.oecd.org/dataoecd/52/35/40140021.pdf

Eurostat (2008). Europe in figures: Eurostat yearbook 2008. Luxembourg: Publications Office.

Fishbein M., \& Ajzen, I. (1975). Belief, Attitude, Intention and Behavior: An Introduction to Theory and Research. Reading (MA): Addison Wesley.

Fishbein, M., \& Stasson, M. (1990). The role of desires, self-predictions and perceived control in the prediction of training session attendance, Journal of Applied Social Psychology, 20, 173-198.

Forrier, A., \& Sels, L. (2003). The concept employability: a complex mosaic. International Journal of Human Resources Development and Management, 3, 102-124.

Fossum, J. A., Arvey, R.D., Paradise, C.A., \& Robbins, N.E. (1986). Modeling the Skills Obsolescence Process: A Psychological/ Economic Integration. Academy of Management Review, 11, 362-374.

Fouarge, D. (2009). Rendement van training laaggeschoolden (The return on the training of less educated people). Economisch Statistische Berichten (ESB), 4559, 272.

Fouarge, D., \& Schils, T. (2009). The effect of early retirement incentives on the training participation of older workers. Labour, 23, 85-109.

Fouarge, D., de Grip, A., \& Montizaan, R. (2011). Pensioenverwachtingen en personeelsbeleid. Verslag van de ROA enquête 2011(Retirement expectations and $\mathrm{Hr}$ policies. ROA survey report 2011), ROA-R-2011/9, Maastricht: ROA.

Fouarge, D., Schils, T., \& de Grip, A. (2013). Why do less educated workers invest less in further training? Applied Economics, 45, 2587-2601.

Geenen, B.A.M., Proost, K., Schreurs, B., van Dam, K., \& Von Grumbkow, J. (2013). What friends tell you about justice: The influence of peer communication on applicants' reactions. Journal of Work and Organisational Psychology, 29, 37-44.

Genabeek, J., \& Wevers, C.W.J. (2009). Trends in Arbeid (Trends in labour), TNO, Hoofddorp. 
Gesthuizen, M., \& Dagevos, J. (2005). Arbeidsmobiliteit in goede banen. Oorzaken van baan en functiewisselingen en gevolgen voor de kenmerken van het werk (Mobility of labour in good jobs. Causes of job and function changes and the impact on the attributes of the work). Den Haag: Sociaal Cultureel Planbureau (SCP).

Gesthuizen, M. (2008). Trends in de arbeidsmarktpositie van lageropgeleiden (Trends in the less educated workforce labour market position), Tijdschrift voor Arbeidsvraagstukken, 24, 3654.

Gesthuizen, M., \& Scheepers, P. (2010). Economic vulnerability among less educated Europeans: Resource, composition, labour market and welfare state influences. Acta Sociologica, 53, 247-267.

Gist, M.E., Schwoerer, C., \& Rosen, B. (1989). Effects of alternative training methods on selfefficacy and performance in computer software training. Journal of Applied Psychology, 74, 884-891.

Golsteyn, B. (2012). Waarom groeit leven lang leren in Nederland niet sterker ondanks de vele adviezen erover? Een onderzoek in opdracht van de onderwijsraad. Maastricht: Universiteit Maastricht.

Goos, M., Manning, A., \& Salomons, A. (2014). Explaining Job Polarization: Routine-Biased Technological Change and Offshoring. American Economic Review, 104, 2509-26.

Görg, (2011). Globalization, offshoring and jobs. In M. Bacchetta, \& M. Jansen (Eds.), Making Globalization Socially Sustainable. Lausanne/Geneva: WTO/ILO.

Görlich, D., \& de Grip, A. (2009). Human capital depreciation during family-related career interruptions in male and female occupations. Oxford Economic Papers, 61, i98-i121.

Gould, E. D., Moav, O., \& Weinberg, B. A. (2002). Skill obsolescence and wage inequality within education groups. The economics of skills obsolescence, 21, 215-234.

Grant, A.M., \& Parker, S.K. (2009). Redesigning work design theories: The rise of relational and proactive perspectives. Academy of Management Annals, 3, 273-331.

Greenhalgh, C., \& Mavrotas, G. (1994). The role of career aspirations and financial constraints in individual access to vocational training. Oxford Economic Papers, 46, 579-604.

Griffeth, R. W., Hom, P. W., \& Gaertner, S. (2000). A meta-analysis of antecedents and correlates of employee turnover: Update, moderator tests, and research implications for the next millennium. Journal of management, 26(3), 463-488.

Gründemann, R., Ybema, J.F., \& Sanders, J. (2014). Werkwaarden van laagopgeleide oudere werknemers. (Work needs of less educated older workers). Gedrag \& Organisatie, 27, 117 138.

Guariglia, A. \& Kim, B.Y. (2006). The dynamics of moonlighting in Russia: what is happening in the Russian informal economy. Economics of Transition, 14, 1-45. 
Hackman J.R., \& Lawler, E.E. (1971). Employee reactions to job characteristics. Journal of Applied Psychology, 55, 259-286.

Hackman, J.R., \& Oldham, G.R. (1976). Motivation through the design of work: Test of a theory. Organizational Behavior and Human Performance, 16, 250-279.

Hackman, J.R., \& Oldham, G.R. (1980). Work redesign. Reading (MA): Addison Wesley.

Hall, D.T., \& Mirvis, P.H. (1995). The new career contract: Developing the whole person at midlife and beyond. Journal of Vocational Behavior, 47, 269-289.

Hazelzet, A., Sanders, J., Langelaan,S., Giesen, F., \& Keijzer, L. (2011). Stimuleren van scholing bij lager opgeleide werknemers (Promoting education for less educated workers), Hoofddorp: TNO.

Heckhausen, J., \& Schulz R. (1995). A life-span theory of control. Psychological review, 102, 440458.

Heckman, J.J., (2000). Policies to foster human capital, Research in Economics, 54, 3-56.

Heineck, G., \& Schwarze, J. (2004). Fly me to the moon: the determinants of secondary jobholding in Germany and UK. IZA Discussion Paper 1358. Bonn: IZA.

Henkens, K., \& van Solinge, H. (2003). Ouderen op de drempel van pensioen (Older people on the retirement threshold). Tijdschrift voor HRM 6, 43-64.

Henkens, K., van Dalen, H.P., \& van Solinge, H. (2009). De vervagende grens tussen werk en pensioen; over doorwerkers, doorstarters en herintreders (The fading line between work and retirement; about people who carry on working, restarters and returners). NIDI report 78. Amsterdam: KNAW Press.

Hennequin, E. (2007). What "career success" means to blue-collar workers. Career Development International, 12, 565 - 581.

Hipple, S. F. (2010). Multiple jobholding during the 2000s. Monthly Labour Review, July, 21-31.

Holte, H.H., Krokstad, S., \& Magnus, P. (2000). Arsaker til Uførepensjonering (Causes of Disability Retirement). Norwegian Institute of Public Health, report No 5, Oslo: NIPH.

Hooftman, W., van der Klauw, M. Klein Hesselink, J., Terwoert, J., Jongen M., Kraan, K. Wevers, C., Houtman, I., \& Koppes L. (2012). Arbobalans 2011, Kwaliteit van de arbeid, effecten en maatregelen in Nederland. (Working Conditions 2011, Quality of work effects and measures in the Netherlands). Hoofddorp: TNO.

Houkes, I., Janssen, P.P.M., de Jonge, J., \& Nijhuis, F.J.N. (2001). Work and Individual Determinants of intrinsic work motivation, emotional exhaustion and turnover intention: a multiple sample analysis. International Journal of Stress Management, 8, 257- 283.

Houtman, I.L.D., Goudswaard, A., Dhondt, S., van der Grinten, M., Hildebrandt, V., \& Kompier, M. (1995). Evaluatie van de monitorstudie naar stress en lichamelijke belasting. (Evaluation of the monitoring study on stress and physical strain). The Hague: VUGA. 
Humphrey, S.E., Nahrgang, J.D., \& Morgeson, F.P. (2007). Integrating Motivational, Social and Contextual Work Design Features: A Meta-Analytic Summary and Theoretical Extension of the Work Design Literature. Journal of Applied Psychology, 92, 1332-1356.

Hurtz, G.M., \& Williams, K.J. (2009). Attitudinal and motivational antecedents of participation in voluntary employee development activities. Journal of Applied Psychology, 94, 635-653.

Huiskamp R, Sanders J., \& van den Bossche, S. (2011) Meerdere banen: noodzaak of uitdaging? (Multiple jobs: necessity or challenge?) Tijdschrift voor Arbeidsvraagstukken, 27, p.156174.

Illeris, K. (2006). Lifelong learning and the low-skilled. International Journal of Lifelong Education, $25,15-28$.

Janssens, M., Sels, L., \& Vandenbrande, I. (2003). Multiple types of psychological contracts: A six-cluster solution. Human Relation, 56, 1349-1378.

Jettinghof, K., \& Smulders, P.G.W (2008). Wie kan en wil doorwerken? (Who want to and who are able to extend their work-life). Tijdschrift voor Arbeidsvraagstukken, 24, 88-100.

Josten, E., \& Schalk, R. (2010). The effects of demotion on older and younger employees. Personnel Review, 39, 195-209

Karasek, R.A. (1979). Job demands, job decision latitude and mental strain. Implications for job redesign. Administrative Science Quarterly, 24, 285-308.

Karasek, R.A. (1985). Job Content Questionnaire and User's Guide. Lowell: University of Massachusetts, Department of Work Environment.

Karasek, R.A., \& Theorell, T. (1990). Healthy work, stress, productivity and the reconstruction of working life. New York: Basic Books.

Karasek, R.A., Brisson, Ch., Kawakami, N., Houtman, I.L.D., Bongers, P., \& Amick, B. (1998). The Job Content Questionnaire (JCQ): an instrument for internationally comparative assessments of psychosocial job Characteristics. Journal of Occupational Health Psychology, 3, 322-355.

Kaufman, H.G. (1989), Obsolescence of Technical Professionals: A Measure and a Model, Applied Psychology: an International Review, 39 (1), pp. 73-85.

Keijzer, L., Oomens, S., \& Hazelzet, A.M. (2009) Scholingsintentie van lageropgeleide werknemers. Resultaten van een eerste meting (Training intention of less educated workers. Results of an initial measurement). Opleiding en Ontwikkeling, 5, 23-26.

Keijzer, L., Stubbé, H., \& Vos, F. (2012) Stappenplan voor de adviseur: verbeteren leercultuur (Multistep plan for the consultant: improving the learning culture). Hoofddorp: TNO.

Kimmel, J., \& Smith Conway, K. (2001). Who moonlights and why? Industrial Relations, 40, 89102. 
Kluger, A.N., \& DeNisi, A. (1996). Effects of feedback intervention on performance: a historical review, a meta-analysis, and a preliminary feedback intervention theory. Psychological Bulletin, 119, 254-284.

Knud, I. (2005). Lifelong Learning and the low-skilled. International Journal of Lifelong Education, $25,15-28$.

Kooij, T.A.M. (2010). Motivating Older Workers: A Lifespan Perspective on the Role of Perceived HR Practices. Amsterdam: VU University (thesis).

Koppes, L., de Vroome, E., Mol, M., Janssen, B., \& van den Bossche, S. (2010). Nationale Enquête Arbeidsomstandigheden 2009: Methodologie en globale resultaten (National Working Conditions Survey 2009: Methodology and overall results). Hoofddorp: TNO.

Koppes L.L.J., de Vroome E.M.M., \& van den Bossche S.N.J. (2011). NEA cohortonderzoek 2007 - 2009; Methoden en eerste resultaten (Netherlands Working Conditions Cohort Study (NWCCS)). Hoofddorp: TNO.

Kraan, K., \& Sanders, J. (2011). Pilot Survey on 'Skills Obsolescence among ageing workers'; results and findings from the Main Phase. Technical Report. Hoofddorp: TNO.

Kraan, K.O., van Zwieten, M.H.J., Sanders, J.M.A.F. \& Wevers, C.W.J. (2014). Monitor duurzame inzetbaarheid - resultaten 2010 en 2012 en methodologie (Monitor sustainable employability - results in 2010 and 2012, and Methodology). TNO-rapportnr, R10197, Hoofddorp.

Kristof, A.L. (1996). Person-organization fit: An integrative review of its conceptualizations, measurement and implications. Personnel Psychology, 49, 1-49.

Kyndt, E., Govaerts, N., Dochy, F., \& Baert, H. (2011). The learning intention of low qualified employees: a key for participation in lifelong learning and continuous training. Vocations and Learning, 4, 211-229.

Kyndt, E., \& Baert, H. (2013). Antecedents of employees' involvement in work-related learning: A systematic review. Review of Educational Research, 83, 273-313.

Lankhuijzen, E.S.K. (2002). Learning in a self-managed management career. Utrecht: Utrecht University.

Lantz, A., \& K. Andersson (2009). Personal initiative at work and when facing unemployment. Journal of workplace learning, 21, 88-108.

Leana, C., Appelbaum, E., \& Shevchuk, I. (2009). Work process and quality of care in early childhood education: the role of job crafting. Academy of Management Journal 52, 11691192.

Leisink, P.L.M., Thijssen, J.G.L., \& Walter, E. (2004). Langer doorwerken met beleid. De praktijk van ouderenbeleid in arbeidsorganisaties (A sensible policy for continuing to work for longer. The practical application of policy on the elderly in labour organizations). Utrecht: USBO. 
Lilja, R. (1991). The problematic and unproblematic second job. Discussion Paper 107. Helsinki: Labour Institute for Economic Research.

Lindsay, C. (2005). Good jobs, 'McJobs' and skills: job seekers' attitudes to low-skilled service work'. Human Resource Management Journal, 15, 50-65.

Livanos, I., \& Zangelidis, A. (2008). Multiple-Job Holding Among Male Workers in Greece. MPRA Paper 17031. Munich: University Library of Munich.

Locke, E.A., \& Latham, G.P. (1990). A theory of goal setting and task motivation. Englewood Cliffs: Prentice Hall

Locke, E.A., \& Latham, G.P. (2002). Building a practically useful theory of goal setting and task motivation. American Psychologist, 57, 705-717.

Luszczynska, A., \& Schwarzer, R. (2005). Social Cognitive Theory. In M. Conner, \& P. Norman (Eds.), Predicting Health Behavior: Research and practice with social cognition (2nd ed.) (pp. 127-169). Open University Press: McGraw-Hill Education.

Major, D.A., Turner, J.E., \& Fletcher, T.D. (2006). Linking proactive personality and the big five to motivation to learn and development activity. Journal of Applied Psychology, 91, 927-935.

Mangum, G.L. (1976). Employability, employment and income: A reassessment of manpower policy. Salt Lake City: Olympus Pub. Co.

Marsick, V.J., \& Watkins, K.E. (2001). Informal and incidental learning. New directions for adult and continuing education, 89, 25-34.

Maslach, C., Schaufeli, W.B., \& Leiter, M.P. (2001). Job Burnout. Annual Reviews of Psychology, 52, 397-422.

Maurer, T.J., \& Tarulli, B.A. (1994). Investigation of perceived environment, perceived outcome and person variables in relationship to voluntary development activity by employees. Journal of Applied Psychology, 79, 3-14.

Maurer, T.J. (2001). Career-relevant learning and development, worker age and beliefs about self-efficacy for development. Journal of Management, 27, 123-140.

Maurer, T.J., Weiss, E.M., \& Barbeite, F.G. (2003). A model of involvement in work-related learning and development activity: the effects of individual, situational, motivational and age variables. Journal of Applied Psychology, 88, 707-724.

McCarthy, A., \& Garavan, T. (2006). Postfeedback development perceptions: applying the theory of planned behavior. Human Resource Development Quarterly, 17, 245-267.

Mesmer-Magnus, J., \& Viswesvaran, C. (2010). The role of pre-training interventions in learning: A meta-analysis and integrative review. Human Resource Management Review, 20, 261282

Millar, R., \& Shevlin, M. (2001). Predicting career information-seeking behavior of student-pupils using the theory of planned behavior. Journal of Vocational Behavior, 62, 26-42. 
Morgeson, F.P., \& Campion, M.A. (2003). Work design. In W.C. Borman, D.R. Ilgen, \& R.J. Klimoski (Eds.), Handbook of psychology: Industrial and organizational psychology, 12, 423-452. Hoboken, NJ: Wiley.

Morgeson, F.P., \& Humphrey, S.E. (2006). The Work Design Questionnaire (WDQ): Developing and validating a comprehensive measure for assessing job design and the nature of work. Journal of Applied Psychology, 91, 1321-1339.

Nauta, A., de Vroome, E., Cox, E., Korver, T., \& Kraan, K. (2005). De invloed van functietype op het verband tussen leeftijd en inzetbaarheid (The influence of job type on the link between age and employability). Gedrag \& Organisatie, 18, 326-337.

Nauta, A., van Vianen, A., van der Heijden, B., van Dam, K., \& Willemsen, M. (2009). Understanding the factors that promote employability orientation: the impact of employability culture, career satisfaction and role breadth self-efficacy. Journal of Occupational and Organizational Psychology, 82(2), 233-251.

Neefs, B., \& Herremans, W. (2011). Werken bij maanlicht! M/V met meerdere jobs op de Vlaamse arbeidsmarkt. Over.werk, 3, 106-115.

Neuman, S., \& Weiss, A. (1995). On the effects of schooling vintage on experience-earnings profiles: Theory and evidence. European Economic Review, 39, 943-955.

Nicoletti, C., \& Peracchi, F. (2001). Aging in Europe: What can we learn from the Europanel?. In T. Boeri, A. Börsch-Supan, A. Bruguavini, R. Disney, A. Kapteyn, \& F. Peracchi, (Eds.), More information, less ideology - Assessing the long-term sustainability of European pensions systems: Data requirements, analysis and evaluations. Boston, Dordrecht and London: Kluwer.

Nieuwenhuis, L., \& Nijman, D. (2008). Een leven lang leren in beeld: een overzicht en analyse van het afgelopen decennium. In C. Doets, W. van Esch, \& A. Westerhuis (Eds.), Een brede verkenning van een leven lang leren (pp. 17-40).'s-Hertogenbosch: Cinop.

Noe, R.A., \& Wilk, S.A. (1993). Investigation of the factors that influence employees' participation in development activities. Journal of Applied Psychology, 78, 291-302.

OECD (2014). Ageing and Employment Policies: Netherlands 2014: Working Better with Age. OECD Publishing. DOI: 10.1787/9789264208155-en

Oeij, P., de Vroome, E., Kraan, K., van den Bossche, S., \& Goudswaard, A. (2011). Werkgevers Enquête Arbeid 2010: Methodologie en beschrijvende resultaten (Employers' Labour Survey 2010: Methodology and descriptive results). Hoofddorp: TNO.

Ohly, S., \& Fritz, C. (2007). Challenging the status quo: What motivates proactive behavior? Journal of Occupational and Organizational Psychology, 80, 623-629.

Oosterbeek, H. (1996). A decomposition of training probabilities. Applied Economics, 28, 799805. 
Oostrum, J. (2007). De effectviteit van een assertiviteitstraining en een communicatietraining. Rotterdam: Erasmus University (master thesis)

Oreg, S., \& van Dam, K. (2009). Organisational justice in the context of organisational change. Netherlands Journal of Psychology, 64, 127-138.

Organisation for Economic Co-operation and Development (OECD) (2006). Employment Outlook 2006. Paris: OECD.

Panos, G.A., Pouliakas, K., \& Zangelidis, A. (2009). The inter-related dynamics of dual job holding, human capital and occupational choice. IZA Discussion Paper 4437. Bonn: IZA.

Parent-Thirion, A., Fernández Macías, E., Hurley, J., \& Vermeylen, G. (2005). Fourth European Survey on Working Conditions. Dublin: European Foundation for the Improvement of Living Standards.

Parker, S.K., Wall, T.D., \& Cordery, J.L. (2001). Future work design research and practice: Towards an elaborated model of work design. Journal of Occupational and Organizational Psychology, 74, 413-440.

Parker, S. K., Bindl, U. K., \& Strauss, K. (2010). Making things happen: A model of proactive motivation. Journal of Management, 36, 827-856. doi:10.1177/0149206310363732

Payne, S.C., Youngcourt, S.S., \& Beaubien, J.M. (2007). A meta-analytic examination of the goal orientation nomological net. Journal of Applied Psychology, 92, 128-150.

Peterson, P.G. (1999). Gray dawn: how the coming age wave will transform America - and the world. New York, NY: Times Books.

Phillipson, C., \& Smith, A. (2005). Extending working life: A review of the research literature. DWP Research Report 299. Leeds: Corporate Document Services.

Podsakoff, N.P., LePine, J.A., \& LePine, M.A. (2007). Differential challenge stressor-hindrance stressor relationships with job attitudes, turnover intentions, turnover and withdrawal behavior: A meta-analysis. Journal of Applied Psychology, 92, 438-454.

Podsakoff, P.M., MacKenzie, S.B., Lee, J.-Y., \& Podsakoff, N.P. (2003). Common method biases in behavioral research: a critical review of the literature and recommended remedies. Journal of Applied Psychology, 88, 879-903.

Poell, R.F., van Dam, K. \& van den Berg, P.T. (2004). Organising learning in work contexts. Applied Psychology: An International Review, 53, 529-540.

Prochaska, J.O., Redding, C.A., \& Evers, K.E. (2002). The transtheoretical model and stages of change. In K. Glanz, B.K. Rimer, \& F.M. Lewis (Eds.), Health behavior and health education: theory, research and practice (3rd ed.) (pp. 99-120).San Francisco, CA: JosseyBass.

Proper, K.I., Deeg, D.J.H., \& van der Beek, A.J. (2009). Challenges at work and financial rewards to stimulate longer workforce participation. Human Resources for Health, 11, 7-70. 
Quinn, J.F. (1978). Job Characteristics and Early Retirement. Industrial Relations, 17 (3), 315323.

Raemdonck, I. (2006). Self-directedness in learning and career processes. A study in lowerqualified employees in Flanders. Ghent: Ghent University. Thesis.

Raemdonck, I., de Grip, A., Segers, M., Thijssen, J., \& Valcke, M. (2008). Zelfsturing in leren en loopbaan als predictoren van employability bij laaggeschoolde werknemers (Self-direction in learning and career as predictors of employability for semiskilled and unskilled workers). Gedrag \& Organisatie, 21, 386-405.

Rau, B.L., \& Adams, G.A. (2005). Attracting Retirees to Apply: Desired Organizational Characteristics of Bridge Employment. Journal of Organizational Behavior, 26, 649-660.

Rainbird, H. (2000). Skilling the unskilled: access to work-based learning and lifelong learning agenda. Journal of Education and Work, 13, 183-197.

Renkema, A. (2006). Individual learning accounts: a strategy for lifelong learning? Journal of Workplace Learning, 18, 384-394.

Renna, F., \& Oaxaca, R.L. (2006). The economics of dual jobholding: a job portfolio model of labour supply. IZA Discussion Paper 1915. Bonn: IZA.

ROA (2009). De Arbeidsmarkt naar Opleiding en Beroep tot 2014 (The labour market by education and occupation to 2014). ROA-R-2009/5. Maastricht: Research Centre for Education and the Labour Market.

Robinson, H., \& Wadsworth, J. (2006). The impact of the minimum wage on the incidence of second job holding in Britain. IZA Discussion Paper 2445. Bonn: IZA.

Rousseau, D.M. (1995). Psychological contracts in organizations: understanding written and unwritten agreements. Thousand Oaks/London: Sage.

Rousseau, D.M. (2005). I-deals: Idiosyncratic deals workers bargain for themselves. New York: M.E. Sharpe.

Ryan, R.M., \& Deci, E.L. (2000). Self-determination theory and the facilitation of intrinsic motivation, social development and well-being. American Psychologist, 55, 68-78.

Ryan, R.M., Lynch, M.F., Vansteenkiste, M., \& Deci, E.M. (2010). Motivation and Autonomy in Counseling, Psychotherapy and Behavior Change: A Look at Theory and Practice. The Counseling Psychologist, 32, 193-260.

Salvanes, K. G. (2004). 9. Education, gender and labour mobility. Human Capital Over the Life Cycle: A European Perspective, 173.

Salverda, W. (2011). Laagbetaald werk, deeltijdwerk en loonmobiliteit (low-wage work, part-time employment and earnings mobility), In R. van Gaalen, J. Sanders, W. Smits, \& J-F. Ybema (Eds.), Dynamiek op de Nederlandse Arbeidsmarkt: De focus op kwetsbare groepen (Dynamics of the Dutch Labour Market: Focus on vulnerable groups) (pp. 209-228). The Hague/Heerlen: Statistics Netherlands. 
Sanders, J., de Grip, A., \& van Loo, J. (2003). Scholing als wapen in de strijd tegen competentieveroudering (Education as a weapon in the battle against skills obsolescence). Tijdschrift voor HRM, 1, 95-115.

Sanders, J., \& de Grip, A. (2004). Training, task flexibility and the employability of low-skilled workers. International Journal of Manpower, 25, 73-89+140.

Sanders, J., Keijzer, L., van Wijk, E., \& Geuskens, G. (2011a). Duurzame inzetbaarheid: inventarisatie van doelgroepen en de noodzaak tot scholing. Hoofddorp: TNO.

Sanders, J., van Wijk, E., Dorenbosch, L., \& Blonk, R. (2011b). Arbeidsmarkttransities van laagopgeleiden (Labour market transitions by the less educated). In R. van Gaalen, J. Sanders, W. Smits, \& J-F. Ybema (Eds.), Dynamiek op de Nederlandse Arbeidsmarkt: De focus op kwetsbare groepen (Dynamics of the Dutch Labour Market: Focus on vulnerable groups) (pp. 43-63). The Hague/Heerlen: Statistics Netherlands (CBS).

Sanders, J., Keijzer, L., Cremer, R., \& Stubbé, H. (2012). De Vakman Nieuwe Stijl; competenties, kenmerken en ontwikkeling en contouren voor een passende leer-werk-omgeving (The $21^{\text {st }}$ Century Skilled Worker; skills, attributes and development and the contours of an appropriate learning-work environment). Hoofddorp: TNO.

Sanders, J., Ybema, J-F., \& van Wijk, E. (2013a). Combinatiebanen en duurzame inzetbaarheid (Multiple jobs and sustainable employability). In R. van Gaalen, A. Goudswaard, J. Sanders, \& W. Smits (Eds.), Dynamiek op de Nederlandse Arbeidsmarkt; de focus op flexibilisering (Dynamics of the Dutch Labour Market: Focus on flexibility) (pp. 121-136). The Hague/Heerlen: Statistics Netherlands (CBS).

Sanders, J., Jetten, A., Dhondt, S., Geuskens, G., Keijzer, L., \& Liebregts, W. (2013b). Mentale Pensionering, een onderzoek naar kenmerken, de determinanten en gevolgen. (Mental retirement, a study into characteristics, determinants and consequences). Hoofddorp: TNO.

Sanders, J., \& Kraan, K. (2013). Kwalificatieveroudering in Nederland, aard en omvang, oorzaken en gevolgen (Skills Obsolescence in the Netherlands, types and prevalence, causes and consequences). Hoofddorp: TNO.

Sanders, J. \& Keijzer, L. (2015a). Verzekerd van vitaal vakmanschap. PW De Gids, November 2015, pp. 14-17.

Sanders, J. \& Keijzer, L. (2015b). Verzekerd van vitaal vakmanschap. OR Informatie, 12 December 2015, pp. 24-25.

Sanders, M. (2005). Technology and the decline of Unskilled labour demand: A Theoretical Analysis of the US and European Labour Markets. Cheltenham: Edward Elgar Publishers.

Schaufeli, W.B. (1990). Opgebrand: Over de achtergronden van werkstress - het burnoutsyndroom (Burned out: About the reasons for work stress - the burnout-syndrome). Rotterdam: Ad Donker. 
Schaufeli, W.B., Salanova, M., González-Romá, V., \& Bakker, A.B. (2002). The measurement of engagement and burnout: A two sample confirmatory factor analytic approach. Journal of Happiness Studies, 3, 71-92.

Schaufeli, W.B., \& Bakker, A.B. (2004). Job demands, job resources and their relationship with burnout and engagement: A multi-sample study. Journal of Organizational Behavior, 25, 293-315.

Schunk, D.H., \& Pajares, F. (2001). The development of academic self-efficacy. In A. Wigfield, \& J. Eccles (Eds.), Development of achievement motivation (pp. 15-32). San Diego, CA: Academic Press.

Seibert, S.E., Kraimer, M.L., \& Crant, J.M. (2001). What do proactive people do? A longitudinal model linking proactive personality and career success. Personnel Psychology, 54, 845874.

Shisko, R., \& Rosker, B. (1976). The economics of multiple jobholding. American Economic Review, 66, 298-308.

Sickles, R.C., \& Taubman, P. (1986). An analysis of the health and retirement status of the elderly. Econometrica, 54, 1339-1356.

Sims, H.P., Szilagyi, A.D., \& Keller, R.T. (1976). The measurement of job characteristics. Academy of Management Journal, 19, 195-212.

Sitzmann, T., Brown, K.G., Casper, W.J., Ely, K., \& Zimmerman, R.D. (2008). A Review and Meta-Analysis of the Nomological Netwerk of Trainee Reactions. Journal of Applied Psychology, 93, 280-295.

Smit, A., Andriessen, S., \& Stark, K. (2005). Lager opgeleiden in beweging. Employability van lager opgeleiden, aanbevelingen en praktijkvoorbeelden. Hoofddorp: TNO.

Smith Conway, K., \& Kimmel, J. (1998). Male labour supply estimates and the decision to moonlight. Labour Economics, 5, 135-166.

Soete, L. L. G., \& Weel, T. B. (2005). The economics of the digital society.

Stamov Roßnagel, C., \& Hertel, G. (2010). Older workers' motivation: Against the myth of general decline. Management Decision, 48, 894-906.

Statistics Netherlands (2008). Gezondheid en zorg in cijfers 2008 (Health and health care in numbers 2008). The Hague: Statistics Netherlands (CBS).

Statistics Netherlands (2010). De Nederlandse Samenleving 2010 (Dutch Society 2010). The Hague/Heerlen: Statistics Netherlands (CBS). 
Statistics Netherlands (2012). Beroepsbevolking; behaalde onderwijs naar herkomst, geslacht en leeftijd. Available at:

http://statline.cbs.nl/StatWeb/publication/?DM=SLNLandPA=71822NEDandD1=2andD2=0a ndD3 $=0$ andD4=0andD5 $=0$ -

3andD6=aandD7=landHDR=T,G1 andSTB=G2,G4,G5,G3,G6andVW=T (accessed 5 July 2013).

Statistics Netherlands (2015). Werkzame beroepsbevolking; vergrijzing per bedrijfstak. Available at:

http://statline.cbs.nl/Statweb/publication/?VW=T\&DM=SLNL\&PA=80832NED\&D1=a\&D2=0 \&D3=0\&D4=0\&D5=0\&D6=0-1,5-22\&D7=0\&D8=a\&HD=1503121136\&HDR=G1,G2,G3,G4,G6,T,G7\&STB=G5 (accessed March 12, 2015).

Steemers, F. J. (2010). Blijvende inzetbaarheid in langere loopbanen.

Stinson, J.F. (Jr.) (1987). Moonlighting: a key to differences in measuring employment growth. Monthly Labour Review, 110, 30-31.

Storm, S., \& Naastepad, R. (2008). Wat de commissie Bakker weten moet (What the Bakker commission should know). Economisch Statistische Berichten (ESB), 4534, 260 - 263.

Stubbé, H.M., \& Theunissen, N.C.M. (2008). Self-directed learning in a ubiquitous learning environment: a meta-review. Proceedings of Special Track on Technology Support for SelfOrganised Learners 2008, 5-28.

Stubbé, H.E., van Schaik, M.G., Theunissen, N.C.M., \& van Meer, J.P. (2010). Eindrapportage TC altijd en overal leren (Final report of the TC learning always and everywhere). Soesterberg: TNO Human Factors.

Sutton, S. (1998). Predicting and explaining intentions and behavior: how well are we doing? Journal of Applied Social Psychology, 28, 1317-1338.

Tannenbaum, S.I., Mathieu, J.E., Salas, E., \& Cannon-Bowers, J.A. (1991). Meeting trainees' expectations: the influence of training fulfilment on the development of commitment, selfefficacy and motivation. Journal of Applied Psychology, 76, 759-769.

Tharenou, P. (2001). The relationship of training motivation to participation in training and development. Journal of Occupational and Organizational Psychology, 74, 599-621.

Theunissen. N.C.M., \& Stubbé, H.E. (2011). Duurzaam leren voor innovatieve werknemers (Sustainable learning for innovative workers). In F. Vaas \& P. Oeij (Eds.), Innovatie die werkt: Praktijkvoorbeelden van netwerk-innoveren (pp. 205-220). Den Haag: Boom|Lemma uitgevers.

Thijssen, J.G.L. (2001). To be employable. Inzetbaarheid in de tweede loopbaanhelft (To be employable. Employability in the second career half). Paper OSA conference, November 2001. Tilburg: OSA. 
Tims, M. (2013). Job crafting: A new perspective on job redesign. Erasmus Universiteit Rotterdam. (thesis)

Trivellato, U. (1999). Issues in the design and analysis of panel studies: a cursory review. Quality and Quantity, 33(3), 339-351.

United Nations (2007). World Economic and Social Survey 2007. Development in an Ageing World. New York (NY): United Nations Publication.

United Nations (2013). World Population Ageing 2013. ST/ESA/SER.A/348.

Urlings, N. (2009). Van werknemer naar ondernemer. Den Haag: Statistics Netherlands (CBS).

Van Breukelen, W., van der Vlist, R., \& H. Steensma (2004). Voluntary employee turnover: combining variables from the 'traditional' turnover literature with the theory of planned behavior. Journal of Organizational Behavior, 25, 893-914.

Van Dalen, H.P., Henkens, K., \& Schippers, J.J. (2007). Oudere werknemers door de lens van de werkgever (Older workers through the lens of the employer). NIDI report no. 74 . The Hague: NIDI.

Van Dam, K. (2005). Employee attitudes toward job changes: An application and extension of Rusbult and Farrell's investment model. Journal of Occupational and Organizational Psychology, 78, 253-272.

Van Dam, K., van der Heijden, B.I.J.M., \& Schyns, B. (2006). Employability and individual development at work. Gedrag \& Organisatie, 19, 53-68.

Van Dam, K. (2013). Employee adaptability to change at work: A multidimensional, resourcebased framework. In S. Oreg, A. Michel, \& R.T. By (Eds.), The psychology of organizational change: Viewing change from the employee's perspective (pp. 123-142). Cambridge: Cambridge University Press.

Van den Bossche, S.N.J., \& Houtman, I. (2007). Stress Impact: Longitudinal quantitative study on long term absent employees: the Netherlands. Hoofddorp: TNO.

Van den Bossche, S.N.J., Koppes, L.L.J., Granzier, J.J.M., de Vroome E.M.M., \& Smulders, P.G.W. (2008). Nationale Enquête Arbeidsomstandigheden 2007: Methodologie en globale resultaten. Hoofddorp: TNO.

Van den Broeck, A., Vansteenkiste, M., de Witte, H., Lens, W. \& Andriessen, M. (2009). De ZelfDeterminatie Theorie: kwalitatief goed motiveren op de werkvloer (The Self-Determination Theory: high quality motivation in the workplace). Gedrag \& Organisatie, 22, 316-334.

Van den Broeck, A., van Ruysseveldt, J., Smulders, P., \& de Witte, H. (2011). Does an intrinsic work value orientation strengthen the impact of job resources? A perspective from the Job Demands-Resources Model. European Journal of Work and Organizational Psychology, 20, 581-609. 
Van der Heijden, B., Boon, J., van der Klink, M., \& Meijs, E. (2009a). Employability enhancement through formal and informal learning: an empirical study among Dutch non-academic university staff members. International journal of training and development, 13(1), 19-37.

Van der Heijden, B. I., De Lange, A. H., Demerouti, E., \& van der Heijde, C. M. (2009b). Age effects on the employability-career success relationship. Journal of Vocational Behavior, 74(2), 156-164.

Van der Heijden, B.I.J.M., Gorgievski, M.J., \& De Lange, A.H. (2016). Learning at the workplace and sustainable employability: a multi-source model moderated by age. European Journal of Work and Organizational Psychology, 25(1), 13-30.

Van der Klink, J.J.L., Bültmann, U., Brouwer, S., Burdorf, A. Schaufeli, W.A., Zijlstra, F.R.H., \& van der Wilt, G.J. (2011). Duurzame inzetbaarheid bij oudere werknemers, werk als waarde. Gedrag \& Organisatie, 24, 324-356.

Van der Stelt, H., \& de Voogd-Hamelink, M. (2009). Trend report: Supply of labour in 2009. The Hague: Ministry of Social Affairs and Employment.

Van Dinther, M., Dochy, F., \& Seegers, M. (2011). Factors affecting students' self-efficacy in higher education. Educational Research Review, 6, 95-108.

Van Dyck, C., Frese, M., Baer, M., \& Sonnentag, S. (2005). Organizational error-management culture and its impact on performance: a two-study replication. Journal of Applied Psychology, 90, 1228-1240.

Van Hooft, E.A.J., Ottervanger, M., \& van Dam, A. (2007). Verklarende factoren van werkzoekgedrag en werkhervatting (Explanatory factors of job-seeking and work resumption behavior). Rotterdam: Erasmus Universiteit.

Van Hooft, E.A.J., Wanberg, C.R., \& van Hoye, G. (2013). Moving beyond job search quantity: Towards a conceptualization and self-regulatory framework of job search quality. Organizational Psychology Review, 3, pp. 3-40.

Van Hooft, E.A.J., Wesdorp, P., Duinkerken, G., \& van Geuns, R. (2010) Het heft in eigen hand: Achtergrondstudie sturen op zelfsturing (Being in control: Background study of managing on self-direction). The Hague: RWI.

Van Loo, J., de Grip, A., \& de Steur, M. (2001). Skills Obsolescence: Causes and Cures. ROARM-2001/3E, Maastricht.

Van Ryn, M., \& Vinokur, A.D. (1992). How did it work? An examination of the mechanisms through which an intervention for the unemployed promoted job search behavior. American Journal of Community Psychology, 20, 577-597.

Van Solinge, H., Henkens, C., \& van Dalen, H.P. (2009). Langer doorwerken; gemakkelijker gezegd dan gedaan (Continuing to work for longer; easier said than done). Demos, bulletin over bevolking en samenleving, 25, 1-4. 
Vansteenkiste, S., \& Verbruggen, M. (2011). Onderzoek "Bedrijfsinterne loopbaantransities" (Study "Internal labour market transitions"). Antwerpen: Universiteit Antwerpen Steunpunt Werk en Sociale Economie.

Van Vuuren, M., \& Dorenbosch, L. (2011). Mooi Werk: naar een betere baan zonder weg te gaan (Beautiful Job: toward a better job, without leaving). Amsterdam: Boom. ISBN 97-894-610547-84.

Van Zwieten, M., Ybema, J-F., \& Geuskens, G. (2011). Arbeidsvoorwaarden en de gewenste pensioenleeftijd (Labour conditions and the desired retirement age). Gedrag \& Organisatie, $24,4,411-427$.

Vaupel, J.W., \& Loichinger, E. (2006). Redistributing work in aging Europe. Science, 312, 19111913.

Vroom, V.H. (1964). Work and Motivation, New York: Wiley.

Warr, P. (2008). Work values: Some demographic and cultural correlates. Journal of Occupational and Organizational Psychology, 81, 751-775.

Warren, J.R., Hoonakker, P.L.T., Carayon, P., \& Brand, J. (2004). Job Characteristics as Mediators in SES-Health Relationships. Social Science and Medicine, 59, 1367-1378.

Wingen, M., \& F. Otten (2008) Fysieke en psychische gezondheid van ouderen naar sociaaleconomische status. Bevolkingstrends 56, 65-72.

Wittekind, A., Raeder, S., \& Grote, G. (2010), A longitudinal study of determinants of perceived employability. Journal of Organizational Behavior, 31: 566-586.

Wrzesniewski, A., \& Dutton, J. E. (2001). Crafting a job: Revisioning employees as active crafters of their work. Academy of Management Review, 26, 179-201.

Wu, Z., Baimbridge, M. \& Zhu, Y. (2009). Multiple job holding in the United Kingdom: evidence from the British Household Panel Survey. Applied Economics, 41, pp. 1-16.

Ybema, J-F., Geuskens, G., \& Oude Hengel, K. (2009). Oudere werknemers en langer doorwerken: Secundaire analyses op de NEA, het NEA-cohortonderzoek en de WEA (Older workers and continuing to work for longer: Secondary analyses on the National Working Conditions Survey, the National Working Conditions Survey cohort study and the Global Working Conditions Survey). Hoofddorp: TNO.

Ybema, J-F., Geuskens, G., \& van den Heuvel, S. (2011a). Study on Transitions in Employment, Ability and Motivation (STREAM). Methodologie en eerste resultaten 2010 (Study on Transitions in Employment, Ability and Motivation (STREAM). Methodology and initial results 2010). TNO report 031.21205/01.03. Hoofddorp: TNO.

Ybema, J-F., Geuskens, G., \& van den Heuvel, S. (2011b). Duurzame inzetbaarheid van ouderen: resultaten van de eerste meting van STREAM (Sustainable employability of older people: results of the first STREAM measurement). Hoofddorp: TNO. 
Ybema, J-F., \& Geuskens, G. (2011c). Transities op de arbeidsmarkt van oudere werknemers. (labour market transitions of older workers). In W. Smits, J. Sanders, R. van Gaalen \& J-F. Ybema, (Eds.), Dynamiek op de Nederlandse Arbeidsmarkt: De focus op kwetsbare groepen (Dynamics of the Dutch Labour Market: Focus on vulnerable groups) (pp. 209228). The Hague/Heerlen: Statistics Netherlands (CBS).

Zinsmeister, J., \& Van Hoof, J. (2013). Ontziebeleid als valkuil: naar een vakmanscenario voor oudere werknemers (Pity policies as a pitfall: toward a professionals-scenario for older workers). Tijdschrift voor Arbeidsvraagstukken, 29, 101-104.

Zwinkels, W., Ooms, D., \& Sanders, J. (2009). Omvang, aard en achtergronden van baan-baanmobiliteit (Scale and nature of, and reasons for, job-to-job mobility). The Hague: Council for Work and Income. 


\section{Summary in Dutch}

Doel van deze studie is een beter inzicht te krijgen in de oorzaken voor de achterblijvende deelname van lager opgeleide (oudere) werknemers aan activiteiten gericht op verduurzaming van inzetbaarheid en het vinden van manieren om die deelname te stimuleren zodat een actuele en toekomstige skills mismatch kan worden voorkomen. Een relevante studie voor zowel bedrijven als werknemers als overheden omdat ook Nederlandse lager opgeleiden worden geacht langer door te werken. Dat is alleen maar mogelijk als deze groep werknemers productief, gezond en inzetbaar blijt en daarvoor is nodig dat ook zij optimaal gebruik kan maken van beschikbare HR instrumenten voor ontwikkeling van kennis en vaardigheden, mobiliteitsinstrumenten en mogelijkheden om taken en banen aan te passen aan de eigen skills.

In hoofdstuk 2 licht ik allereerst het begrip 'duurzame inzetbaarheid' toe als een dynamisch proces waarbij een individu in zijn eigen (werk)context de match bewaakt tussen dat wat hij of zij kan en dat wat hij of zij bereid is te doen (vaardigheden, capaciteiten en motivatie) en de eisen die het werk aan hem of haar stelt en tussen dat wat het werk biedt en wat hij of zij uit werken wil halen (zingeving). Ik laat zien dat de individuele inzetbaarheid min of meer constant kwetsbaar is als gevolg van steeds terugkerende 'mismatches' en dat mensen voor het herstel van de match gerichte strategieën kunnen inzetten om mismatches (tijdelijk) teniet te doen. Die strategieën noem ik 'verduurzamingsroutes'. Ik behandel er drie: de ontwikkelroute, de mobiliteitsroute en de taakontwerp-route.

De ontwikkelroute verwijst naar activiteiten die erop gericht zijn iemands vaardigheden aan te passen aan de vaardigheden die het werk vereist (of zal gaan vereisen in de toekomst). Dat kan bijvoorbeeld via training en scholing. De mobiliteitsroute verwijst naar een verplaatsing van werknemers binnen of buiten de organisatie met het doel om werk te vinden dat beter past bij de eigen vaardigheden dan het huidige werk. De taakontwerp-route verwijst naar het optimale gebruik van vaardigheden van een werknemer in de huidige baan door taken en processen in het werk zelf te veranderen. Ontwikkeling, mobiliteit en taakherontwerp zijn de routes die bij duurzame inzetbaarheid herhaaldelijk worden gevolgd en die ook veelvuldig worden afgewisseld om de fit tussen werknemer en werk optimaal te houden, en de inzetbaarheid van werknemers te ondersteunen. Op alle drie deze routes blijken laagopgeleiden ondervertegenwoordigd. In dit proefschrift ga ik op zoek naar verklaringen en manieren om hierin verandering te brengen. 
In hoofdstuk 3 gebruik ik longitudinale data om te onderzoeken hoe lager opgeleide medewerkers kunnen worden gestimuleerd deel te nemen aan training. Voortbouwend op Ajzen en Fishbeins theorie van het geplande gedrag (Fishbein \& Ajzen, 1975; Ajzen, 1985; 1991) en Bandura's Sociaal Cognitieve Leerbenadering (Bandura, 1982) laat ik zien dat verschillen in trainingsdeelname grotendeels worden verklaard door verschillen in opleidingsintenties en dat deze intenties kunnen worden gestimuleerd door het verbeteren van iemands algemene houding ten aanzien van opleiding en scholing ('training is een goede zaak') en door het vertrouwen in het succesvol kunnen afronden van een training te versterken ('ik kan met succes deel te nemen aan opleiding').

Voortbouwend op de resultaten in hoofdstuk 3, laat ik in hoofdstuk 4 zien dat trainingsdeelname als zodanig geen invloed heeft op dat vertrouwen. Alleen als trainingsdeelname een positieve ervaring is, heeft die deelname wel een positief effect op vertrouwen. Op basis van deze bevindingen stel ik voor zowel steun van management als steun van medewerkers in de eerste plaats te richten op het verhogen van de kwaliteit van leerervaringen van lager opgeleide werknemers. Positieve leerervaringen blijken immers een trigger voor meer trainingsdeelname en daarmee stimuleert die positieve ervaring ook een leven lang leren.

In hoofdstuk 5 analyseer ik of het vertrouwen van lager opgeleide werknemers in het kunnen vinden van een nieuwe werkgever te versterken is en of dat vrijwillige externe mobiliteit stimuleert. Deze studie richt zich specifiek op lager opgeleide oudere werknemers (leeftijd 45-64). Ik laat zien dat het vertrouwen in de eigen capaciteiten inderdaad positief gecorreleerd is met zowel de intentie om van werkgever te veranderen als met de feitelijke baan-baan-mobiliteit. Ik toon ook aan dat lager opgeleide oudere werknemers minder vertrouwen hebben in het kunnen veranderen van baan en dat zij ook minder vaak de intentie hebben om dat te doen dan hoger opgeleide oudere werknemers. De relatie tússen het vertrouwen en de intentie is echter niet anders onder lager opgeleide werknemers dan onder hoger opgeleide. Deze bevindingen impliceren dat het versterken van het vertrouwen van lager opgeleide 45-plussers in succesvolle baan-baan-mobiliteit kan leiden tot meer vrijwillige externe mobiliteit. Om die vrijwillige externe mobiliteit te kunnen bevorderen ligt het derhalve voor de hand vooral te kijken naar mogelijkheden om het vertrouwen in het kunnen veranderen van baan te bevorderen en, analoog aan de bevindingen in hoofdstuk 4 over trainingsdeelname, lijkt daar het opdoen van positieve ervaringen met loopbaanstappen aan te kunnen bijdragen. Hoe dat laatste zou kunnen worden bewerkstelligd, zou nader kunnen worden onderzocht.

In hoofdstuk 6 onderzoek ik vervolgens welke vormen van taakherontwerp kunnen leiden tot meer duurzame banen voor lager opgeleide oudere werknemers. De studie bouwt voort op het 
'klassieke' Job Characteristics Model en recente uitbreidingen op dit model. Ik laat zien dat lager opgeleide oudere werknemers hoger scoren op 'contextuele' werkkenmerken zoals gevaarlijk werk, fysieke belasting en repetitief werk en toon ook aan dat deze contextuele werkkenmerken negatief gerelateerd zijn aan het arbeidsvermogen en de arbeidsvreugde van werknemers. Deze bevindingen suggereren dat herontwerpen van contextuele werkkenmerken veelbelovend is voor lager opgeleide oudere werknemers. 'Cognitief informatieve' werkkenmerken, zoals de complexiteit van de taak, tijdsdruk of taakeisen, zijn niet gerelateerd aan werkvermogen of werkmotivatie. Herontwerpen van banen op deze kenmerken lijkt daarmee minder veelbelovend. Van de 'taak motiverende' werkkenmerken lijkt alleen het vergroten van de taakdiversiteit een veelbelovende strategie. Op 'sociaal relationele' kenmerken, zoals sociale steun van collega's of leidinggevenden, emotionele werkbelasting en contact met klanten, laat ik zien dat lager opgeleide oudere werknemers vooral kunnen profiteren van een vergroting van de steun en een vermindering van de emotionele werkbelasting. Deze resultaten suggereren dat taakherontwerp een veelbelovende strategie is voor verduurzaming van de inzetbaarheid van lager opgeleide oudere werknemers. Prioriteit zou daarbij moeten uitgaan naar het herontwerp van vooral sociaal-relationele en contextuele werkkenmerken.

In hoofdstuk 7 ga ik ten slotte in op de relatie tussen deelname aan activiteiten op de drie verduurzamingsroutes en de kans dat lager opgeleide oudere werknemers herstellen van een door henzelf waargenomen kennistekort. Ik laat zien dat lager opgeleide oudere werknemers die deelnemen aan meer substantiële training meer kans hebben om te herstellen van een waargenomen tekort aan vaardigheden. Of lager opgeleide oudere werknemers instructies krijgen of 'training on the job' maakt echter geen verschil. Ik laat ook zien dat de onderzochte activiteiten op de mobiliteitsroute (baan-baan mobiliteit, promotie of demotie) en de taakherontwerproute (meer taken, minder taken of andere taken) de kans op het dichten van een waargenomen kennistekort niet vergroot. Demotie en het krijgen van minder taken verkleinen zelfs die kans. Ik laat ten slotte zien dat oudere werknemers die werkzaam zijn in organisaties die nauwelijks reorganiseren meer kans hebben om te herstellen van een waargenomen kennistekort dan oudere werknemers die in minder stabiele organisaties, waar juist vaak wordt gereorganiseerd. In een stabiele omgeving herstellen oudere werknemers dus beter van ervaren kennistekorten dan in een instabielere werkomgeving. Dat geldt echter voor zowel laag als hoger opgeleide oudere werknemers.

Belangrijkste conclusie van dit proefschrift is dat er geen reden is om voor lager opgeleiden en lager opgeleide ouderen nieuwe HR instrumenten te ontwikkelen. Het gaat er vooral om de toegang tot en het gebruik van het bestaande instrumentarium onder lager opgeleiden gericht te stimuleren. Dat kan door instrumenten laagdrempeliger of 'kleiner' te maken, zodat lager 
opgeleide werknemers ze niet links laten liggen vanwege bijvoorbeeld een gebrek aan vertrouwen dat ze er succesvol gebruik van kunnen maken. Dat kan ook door ervoor te zorgen dat lager opgeleiden díe gebruik maken van instrumenten dat ook echt als een positieve ervaring zien. Negatieve ervaringen met school weerhouden veel lager opgeleiden ervan deel te nemen aan opleidingen, maar nieuwe positieve ervaringen met leren zouden juist de kans op een volgende deelname aan scholing en ontwikkeling kunnen vergroten en zo bijdragen aan hun duurzame inzetbaarheid. Hoe van een leerervaring een positieve ervaring te maken vraagt nog nader onderzoek. Dat geldt overigens niet alleen voor deelname aan activiteiten op de ontwikkelroute, maar ook voor deelname aan activiteiten op de andere verduurzamingsroutes die in dit proefschrift aan de orde komen. Een andere conclusie uit dit proefschrift is dat vrijwillige externe mobiliteit onder laagopgeleide oudere werknemers achterblijft als gevolg van een gebrek aan vertrouwen onder laagopgeleide oudere werknemers in het succesvol kunnen veranderen van werkgever. Ook vrijwillige externe arbeidsmobiliteit onder laagopgeleiden lijkt dus te kunnen worden gestimuleerd door werknemers positieve ervaringen te laten opdoen met vormen van externe mobiliteit. Dit proefschrift laat ook zien dat er mogelijkheden zijn om banen beter te laten passen bij lager opgeleide oudere werknemers door bijvoorbeeld steun te vergroten, contacten met klanten te stimuleren en meer afwisseling van taken te bieden. Als dat soort veranderingen ín een baan als positief ervaren worden zou daarmee overigens ook het vertrouwen in het kunnen doormaken van andere veranderingen ín de baan, maar ook veranderingen van baan, verder kunnen worden versterkt.

Uit dit proefschrift blijkt ten slotte nog dat lager opgeleide oudere werknemers in organisaties waar niet of nauwelijks wordt gereorganiseerd een grotere kans hebben te herstellen van ervaren kennistekorten dan laagopgeleide oudere werknemers in organisaties waar juist vaak wordt gereorganiseerd. Dat impliceert dat bijhouden van veranderingen voor laagopgeleide oudere werknemers een uitdaging is en dat verandering bij voorkeur ook in geleidelijkheid zou moeten plaatsvinden. Om te voorkomen dat ervaren kennistekorten structureel worden en werknemers er niet meer van kunnen herstellen, zouden organisaties bij grote en opeenvolgende reorganisaties goed moeten monitoren in hoeverre hun werknemers kennistekorten ervaren en in welke mate zij hiervan herstellen. Desnoods zou een reorganisatie kunnen worden uitgesteld of vertraagd om ervoor te zorgen dat ook laagopgeleide en oudere werknemers erin meegaan, zeker als het om groepen werknemers gaat met schaarse kennis en vaardigheden. Of het temporiseren van reorganisaties haalbaar is en of het ook helpt, valt te bezien. Daarvoor is meer onderzoek nodig naar de effecten van reorganisaties op door werknemers ervaren kennistekorten en de consequenties van die ervaren kennistekorten voor werknemers en arbeidsorganisaties. 


\section{Biography}

Jos Maarten Arnold Frank Sanders was born in Helmond, the Netherlands, on September 29, 1973. In 1998, he graduated from the Master program in Human Resources Studies at Tilburg University. He also holds a Bachelor degree in Sociology from Tilburg University. Before joining $\mathrm{ROA}$ as a PhD candidate in 2012, he worked at ROA from 1998-2004 as a researcher. In 2004 Jos joined TNO (www.tno.nl) and is currently their Senior Scientist HR for Sustainable Productivity and Employability (SPE). As from 2004 Jos has worked on a number of national and international studies on labour market dynamics, employment and employability. Jos has studied and advised in different sectors of industry, such as pharmacy, housing corporations, health sector, energy sector and defence personnel on different labour market related topics such as recruitment and retention, combining learning and working and stronger cooperation with initial and post-initial education suppliers. Jos also co-designed the longitudinal Study on Health at Work (SHAW), Netherlands Establishment Work Survey (NEWS), the Sustainable Employability Monitor and the, Cedefop commissioned, Pilot Survey on Skills Obsolescence among Ageing Workers. Jos is co-editor of multiple books on labour market dynamics in the Netherlands, precarious workers and flexibility. 


\section{ROA Dissertation Series}

1. Lex Borghans (1993), Educational Choice and Labour Market Information, Maastricht, Research Centre for Education and the Labour Market.

2. Frank Cörvers (1999), The Impact of Human Capital on International Competitiveness and Trade Performance of Manufacturing Sectors, Maastricht, Research Centre for Education and the Labour Market.

3. Ben Kriechel (2003), Heterogeneity Among Displaced Workers, Maastricht, Research Centre for Education and the Labour Market.

4. Arnaud Dupuy (2004), Assignment and Substitution in the Labour Market, Maastricht, Research Centre for Education and the Labour Market.

5. Wendy Smits (2005), The Quality of Apprenticeship Training, Conflicting Interests of Firms and Apprentices, Maastricht, Research Centre for Education and the Labour Market.

6. Judith Semeijn (2005), Academic Competences and Labour Market Entry: Studies Among Dutch Graduates, Maastricht, Research Centre for Education and the Labour Market.

7. Jasper van Loo (2005), Training, Labor Market Outcomes and Self-Management, Maastricht, Research Centre for Education and the Labour Market.

8. Christoph Meng (2005), Discipline-Specific or Academic? Acquisition, Role and Value of Higher Education Competencies, Maastricht, Research Centre for Education and the Labour Market.

9. Andreas Ammermüller (2007), Institutional Effects in the Production of Education: Evidence from European Schooling Systems, Maastricht, Research Centre for Education and the Labour Market.

10. Bart Golsteyn (2007), The Ability to Invest in Human Capital, Maastricht, Research Centre for Education and the Labour Market.

11. Raymond Montizaan (2010), Pension Rights, human capital development and well-being, Maastricht, Research Centre for Education and the Labour Market.

12. Annemarie Nelen (2012), Part-Time Employment and Human Capital Development, Maastricht, Research Centre for Education and the Labour Market.

13. Jan Sauermann (2013), Human Capital, Incentives, and Performance Outcomes, Maastricht, Research Centre for Education and the Labour Market

14. Harald Ulrich Pfeifer (2013), Empirical Investigations of Costs and Benefits of Vocational Education and Training, Maastricht, Research Centre for Education and the Labour Market. 
15. Charlotte Büchner (2013), Social Background, Educational Attainment and Labor Market Integration: An Exploration of Underlying Processes and Dynamics, Maastricht, Research Centre for Education and the Labour Market.

16. Martin Humburg (2014), Skills and the Employability of University Graduates, Maastricht, Research Centre for Education and the Labour Market.

17. Jan Feld (2014), Making the Invisible Visible, Essays on Overconfidence, Discrimination and Peer Effects, Maastricht, Research Centre for Education and the Labour Market.

18. Olga Skriabikova (2014), Preferences, Institutions, and Economic Outcomes: an Empirical Investigation, Research Centre for Education and the Labour Market.

19. Gabriele Marconi (2015), Higher Education in the National and Global Economy, Research Centre for Education and the Labour Market.

20. Nicolas Salamanca Acosta (2015), Economic Preferences and Financial RiskTaking, Research Centre for Education and the Labour Market.

21. Ahmed Elsayed Mohamed (2015), Essays on Working Hours, Maastricht, Research Centre for Education and the Labour Market.

22. Roxanne Amanda Korthals (2015), Tracking Students in Secondary Education, Consequences for Student Performance and Inequality, Maastricht, Research Centre for Education and the Labour Market.

23. Maria Zumbuehl (2015), Economic Preferences and Attitudes: Origins, Behavioral Impact, Stability and Measurement, Maastricht, Research Centre for Education and the Labour Market.

24. Anika Jansen (2016), Firms' incentives to provide apprenticeships - Studies on expected short- and long-term benefits, Maastricht, Research Centre for Education and the Labour Market.

25. Jos Maarten Arnold Frank Sanders (2016), Sustaining the employability of the low skilled worker: Development, mobility and work redesign, Maastricht, Research Centre for Education and the Labour Market. 